\title{
Building Urban Community on the Margins: Stratonikeia and the Sanctuary of Zeus at Panamara
}

While Lagina was a local shrine that grew and expanded with Stratonikeia to become its religious center, the sanctuary of Zeus Karios at Panamara was already recognized as an important regional cult center in southern Karia. ${ }^{1}$ However, it, too, was gradually drawn into the orbit of Stratonikeia to become the next major urban sanctuary of the polis. This case study explores yet another kind of dynamic in the transition to polis sanctuary, one that entailed a major lateral shift in scope for Panamara, from the wider region of southern Karia with diverse communities towards the urban center in the north and its demographic base (Figure 6.1, and Figure 5.1 above). Through an examination of this transition it will become apparent how Stratonikeia came to replace, or absorb, the administering body of the sanctuary, but also how Panamara was used to achieve the same kinds of goals of the emerging polis as was Lagina: territorial integrity, social cohesion, and global recognition, albeit in a different way.

Panamara and its environment have unfortunately not been subject to the same systematic archaeological investigations as Lagina, and much of the original landscape in the area has already been lost in the exploitation of lignite, or brown coal, through strip-mining. Our sources for this sanctuary and its environment are therefore severely limited, especially with regard to architecture and processional routes. Fortunately, however, the communities involved with the sanctuary at Panamara left hundreds of inscriptions behind that provide valuable insights into the way in which the sanctuary and cult of Zeus Karios were gradually realigned to meet the needs of Stratonikeia.

1 This section draws on Williamson (2009), (2012), (2013b), (2020b), and (2020c). I would also like to express my thanks to Riet van Bremen, who has kindly commented on an earlier version (Williamson (2012)). Her work has been an inspiration, which will be apparent especially in this case study. 


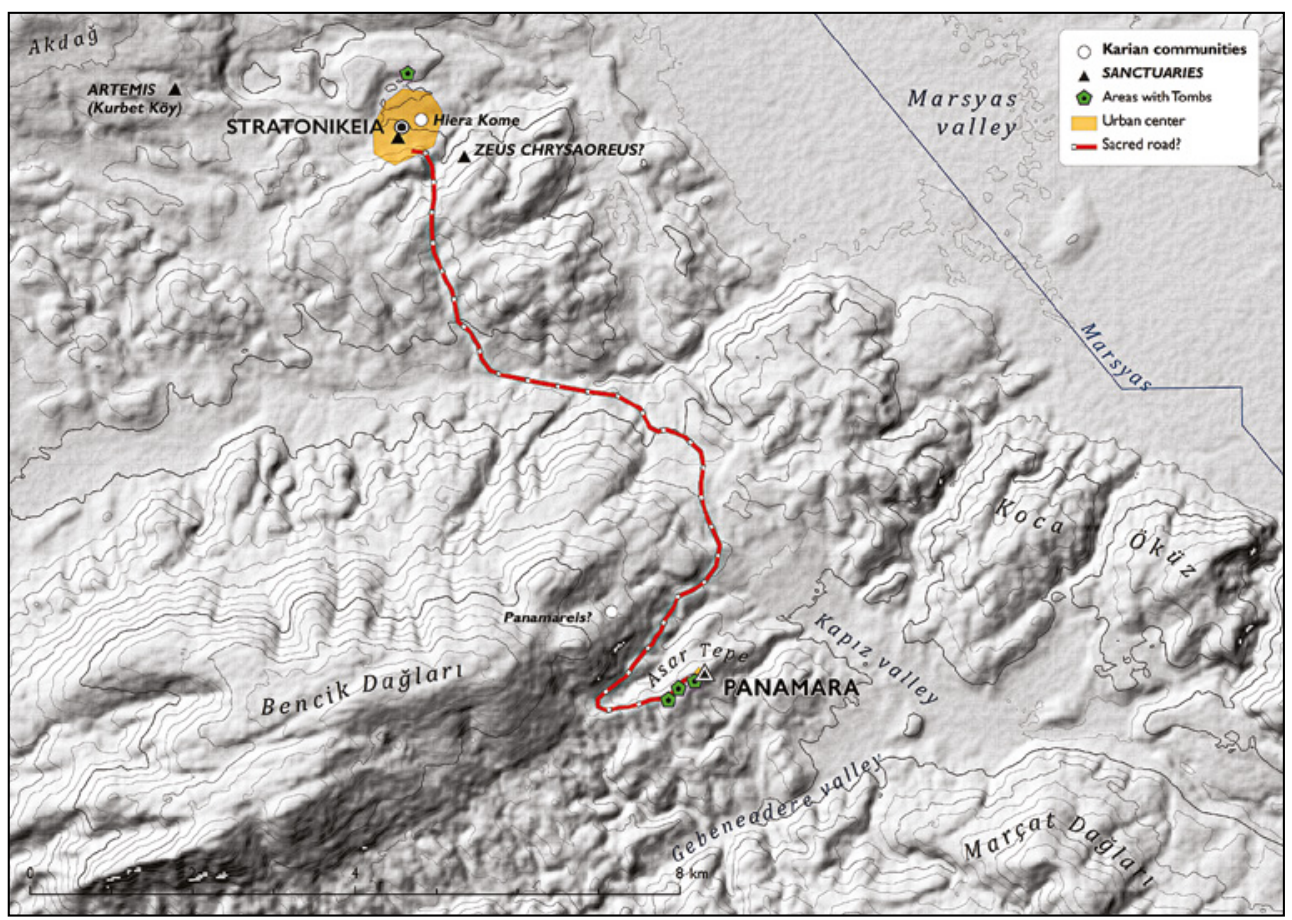

FIGURE 6.1 Panamara and environment, with an indication of the sacred road

The sanctuary of Zeus at Panamara served as a stage for negotiating relations with the changing rulers. ${ }^{2}$ The community at the sanctuary had to deal with the Ptolemies, Philip v, the Rhodians, and finally the polis of Stratonikeia. Riet van Bremen has aptly described it as a barometer of the political upheaval in this area in the third and second centuries BC. ${ }^{3}$ But it is equally a barometer of religious strategy and the communal gravity of cult.

The earliest inscription known from Panamara is dated to the 27os, or just before the Seleukid foundation of Stratonikeia; this is a fragmented decree

2 Panamara is also under study as part of the $\mathrm{PhD}$ research of Serdal Mutlu, at the University of Zurich, on the revival of religious traditions under the Roman Empire, also Mutlu (2015).

3 See van Bremen (2008), 1408: “... le destin mouvementé de Panamara au cours du III ${ }^{\mathrm{e}}$ et du $\mathrm{II}^{\mathrm{e}}$ siècle peut servir en quelque sorte de baromètre pour mesurer les bouleversements politiques affectant la région dans son ensemble." I am grateful to Riet van Bremen for providing access to this article prior to its availability in the Netherlands. 
mentioning Ptolemy II Philadelphus. ${ }^{4}$ Another reference to Ptolemy II in conjunction with Panamara was made in a fragmented inscription from Labraunda. ${ }^{5}$ Both inscriptions support Pierre Debord's observation of Ptolemaic influence in the area of Stratonikeia, or Hiera Kome, in the first part of the third century, prior to the advent of the polis. ${ }^{6}$

Little is known of the sanctuary until the end of this century, although it may for a time already have been under Rhodian control. A decree at Panamara honoring a Rhodian commander, believed to date from the first part of the second century, when Rhodes was formally given control over the area, has been shown by van Bremen to have strong analogies with other decrees from the third century. ${ }^{7}$ This would support John Ma's view of Rhodian possession of the area prior to Philip v's occupation in 201 BC. ${ }^{8}$ This inscription in any event shows that the koinon, or community, of the Panamareis was in control of the sanctuary of Zeus Karios at Panamara, and were using it as a political platform. ${ }^{9}$

At the end of the third century вс, Philip v exploited the strategic setting of the sanctuary and used it as a garrison for his troops who were stationed in this area (Figure 6.2). ${ }^{10}$ That he did this with respect for the cult of Zeus is demonstrated by the honorific decree that the Panamareis had inscribed for him, showing their gratitude for his piety. ${ }^{11}$ They also honored his epistates, or territorial commander, Asklepiades (of Peuma?) for rebuilding the walls of the sanctuary after an earthquake. ${ }^{12}$ Both inscriptions are also the first indications

$4 \quad$ I.Stratonikeia 1400 ; first published in van Bremen (2003b).

$5 \quad$ I.Labraunda 44. This is interpreted as a decree of ateleia, or tax exemption, for Labraunda on behalf of Ptolemy II issued by the Chrysaoric League, which was active here in this period; the decree is dated to $267 \mathrm{BC}$.

6 Debord (2001a), 160-161, associating this with the evidence for the Serapeion and the worship of the Egyptian gods.

$7 \quad$ I.Stratonikeia 6. On the date see van Bremen (2008), 1412-1413, also discussed below, under Administration and Priesthoods. There are fewer indications for the date of I.Stratonikeia 5 , another honorific decree for a Rhodian, but because of the parallels with I.Stratonikeia 6 , van Bremen suggests it may also have a third century date.

8 Ma (1999), 277-278; see also the overview of Stratonikeian history in the beginning of this chapter.

9 The nature of settlement of the community of the Panamareis is as of yet unknown; typically this would have been a koinon. Koina were common in Karia, the term is loosely used to indicate some form of syndicate or federated identity, ranging from dispersed households to villages, to clusters of communities, see Debord (2003). I.Stratonikeia III, 9-10 suggests that the settlement at Panamara may even have been regarded as a polis.

10 Discussed in Holleaux (1952), 205-210.

11 I.Stratonikeia 3 , dated to 201 BC.

12 I.Stratonikeia 4, dated to 198 вс. 


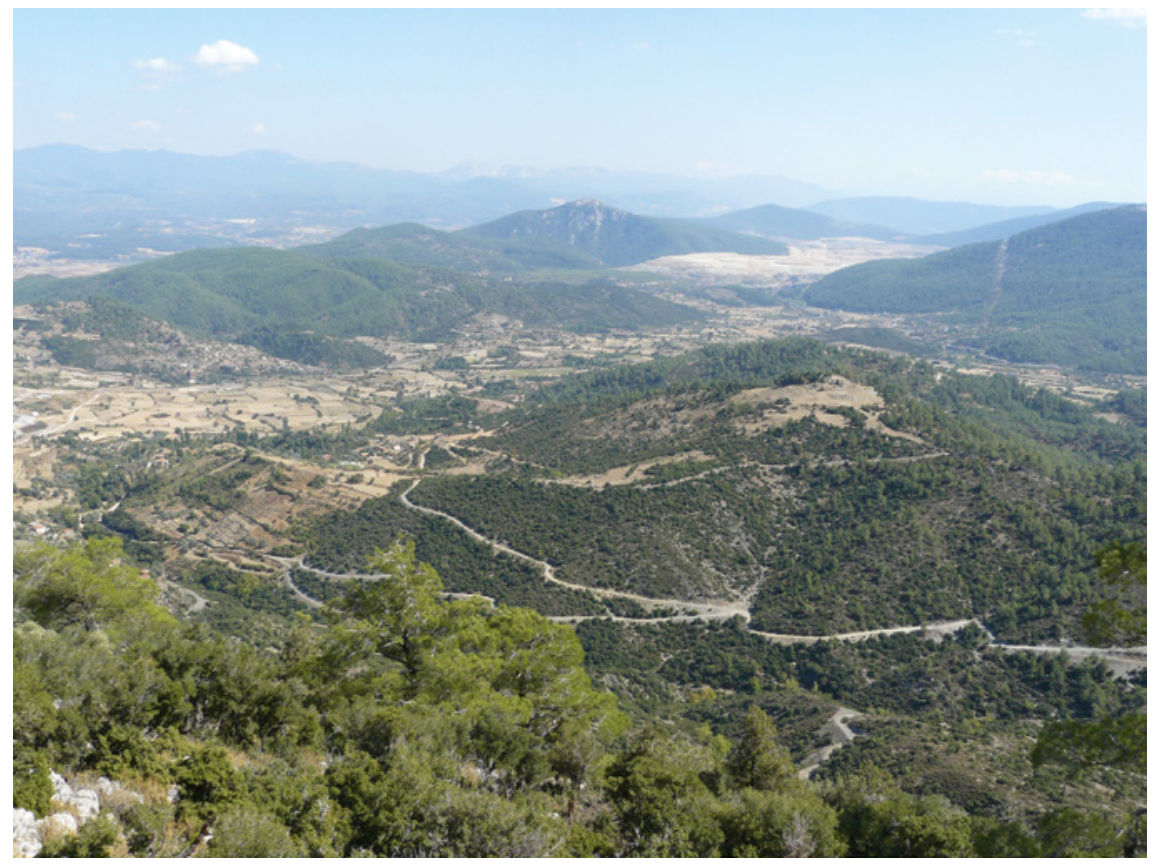

FIGURE 6.2 Panamara, seen from the Bencik Dağı northwest of the sanctuary, looking south. The sanctuary is near the bare spot on the hill just right of the center. Left of Panamara is the Kapız valley with the Koca Öküz hills on the opposite side; the Marsyas valley is in the far left PHOTO AUTHOR 2011

of monumental architecture at the sanctuary, since the decree for Philip was to be inscribed on the door jamb of the temple. ${ }^{13}$

Philip's hold over the area came to an end through Antiochos III in 197 BC, who subsequently handed the area over to Rhodes. ${ }^{14}$ The Panamareis honored a Rhodian epistates at the sanctuary, who had also displayed piety before Zeus. ${ }^{15}$ This event is dated to the priesthood of Archidamos, who was priest of Helios, and one of the eponymous figures used to mark the Rhodian calendar the decree thus appears to date to $18 \mathrm{O}-17 \mathrm{O} \mathrm{BC.} .^{16}$

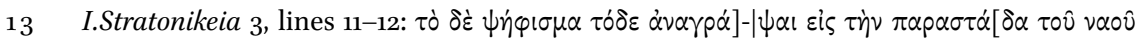

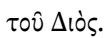

14 This is seen as an indication of Rhodian control prior to Philip's occupation, Ma (1999), 277-278.

15 I.Stratonikeia 9.

16 The names of the eponymous priests of Helios were also stamped as date onto Rhodian amphoras; the chronology of these was initially provided by Grace (1953), but has since 
The eponymous official used to date such decrees points to the identity of the administrative power over the community, which in this case was clearly Rhodes. The earlier decree for Philip's epistates, however, was dated by a stephanephoros, Apollonos, apparently from Stratonikeia. ${ }^{17}$ This raises the question of the degree of control that Stratonikeia may or may not have had over Panamara while it was still being run by the koinon of the Panamareis. Alfred Laumonier believed that Stratonikeia had annexed both Lagina and Panamara early on in its colonial history. For Panamara he bases this primarily on a sacrificial calendar that shows the introduction of Hera to the cult. This had been dated to the third century $\mathrm{BC}$, but is now believed to originate in the later second or first century. ${ }^{18}$ Hans Oppermann understood the sanctuary and especially the koinon of the Panamareis to be much more autonomous, though perhaps not entirely independent from Stratonikeia. ${ }^{19}$ Van Bremen leaves room for both interpretations, explaining the use of the Stratonikeian stephanephoros as a sign that both polis and sanctuary were ultimately ruled by Philip v, who used Stratonikeia as the closest administrative center; in fact he may have been the one to add Panamara to Stratonikeia's territory. ${ }^{20}$ The situation may then have been left intact during Rhodian rule. Jeremy LaBuff considers the possibility of a sympoliteia as a prelude to Panamara's absorption by the polis. ${ }^{21}$

The relationship between the city and the sanctuary in this period was in any event very loose, if it even existed. At some point, however, the polis gained significant clout at Panamara, since they were able to appoint a priest, named Leon, during the administration by the koinon of the Panamareis. ${ }^{22}$ Primarily due to this latitude, the priesthood of Leon is generally dated to the period

been revised by Finkielsztejn (2001); the priesthood of Archidamos is thus seen to fall between the years 180 and $170 \mathrm{OC}$, see van Bremen (2008), 1411-1412.

17 See the discussion in van Bremen (2004b), 231.

18 Laumonier (1958), 234-235. On the date of I.Stratonikeia 1, see van Bremen (2004b), 222227, discussed in more detail below, under Festivals. On Hera at Panamara, Williamson (2020b), also Pirenne-Delforge and Pironti (2016), 186, n. 431 and 194, n. 468.

19 Oppermann (1924), 25-30; see also Debord (1994), 114 and Gabrielsen (2000), 163-167.

$20 \quad$ Van Bremen (2004b), 234.

$21 \quad$ LaBuff (2016), 135 .

22 I.Stratonikeia 7 is a fragment of an honorific decree by the koinon of the Panamareis for the priest Leon, appointed by Stratonikeia; the other two decrees are by the town Kallipolis (I.Stratonikeia 1401 (= Şahin (1995), no. 1)) and by the koinon of the Laodikeis (I.Stratonikeia 1402 (= Şahin (1995), no. 2)). The more recent discovery of the inscriptions from Kallipolis and Laodikeis complements the dedication by the Panamareis, proving that Leon had been appointed by Stratonikeia (I.Stratonikeia 7 , line 23). See van Bremen (2004b) for a detailed discussion of these documents. 
following $167 / 6$ BC, when the Rhodians were forced to withdraw from central Karia by Rome. ${ }^{23}$ A highly motivated man, Leon breathed new life into the cult by using an ancient grant of inviolability, or asylia, which he found in the archives of the sanctuary, to engage several of the communities affiliated with Panamara to acknowledge and celebrate this right, perhaps including Stratonikeia. ${ }^{24}$

These inscriptions reveal many aspects of this transitional period for Panamara and Stratonikeia, who were now both independent from Rhodes. First, the reception of Leon's initiatives and the reference to the past shows that Panamara had apparently slipped into decline under Rhodian rule. Second, Stratonikeia was obviously able to appoint Leon as priest at this sanctuary, several kilometers away, and, third, the koinon of the Panamareis heartily welcomed this intervention; Leon had certainly done them a great service as well. Ironically, however, this is also the last that we hear of them. Leon was clearly building up the cult network of Panamara, and van Bremen suggests that he was not acting out of self-interest. ${ }^{25}$ Panamara is roughly midway between Stratonikeia and the Gulf of Keramos where Stratonikeia's ambitions lay. ${ }^{26}$ Stratonikeia had a vested interest in this area and once freed from Rhodian

23 See especially van Bremen $(2004 \mathrm{~b})$ on the date of the honorific decrees at Panamara for Leon, priest of Stratonikeia. As critical as the timing of Leon's appearance is, the chronology is complicated. Şahin takes a very different view as to the date and origin of the priest Leon, discussed in I.Stratonikeia III, p. 11-12 (in connection with I.Stratonikeia 1401 and 1402). Şahin follows Oppermann (1924), 24-30 and Jacoby (FGrH 278) in assigning Leon's hometown to Alabanda, believing that he acquired Stratonikeian citizenship after his admission into the koinon of the Panamareis; for the chronology, he follows Oppermann's suggestion of shortly before Rhodian control in 188 BC, and for I.Stratonikeia 1401 and 1402 he follows Reger, who suggested a date of $175^{-167}$ BC, i.e. during Rhodian rule, Reger (1998), 16-17. Reger's dating is based on the appearance of the Rhodian priest Eudamos as timestamp for the Laodikeian inscription (I.Stratonikeia 1402); Eudamos also figures on Rhodian amphoras that were dated to this period by Grace (1953). This chronology, however, has since been significantly revised and downdated by Finkielsztejn (2001). The impact of this is of course wide, see Lund (2011), and has consequences for the context of the inscription of the Laodikeis (I.Stratonikeia 1402), as discussed in van Bremen (2004b), 209-210, where she observes that Reger now suggests a later date of $15 \mathrm{O}-148 \mathrm{BC}$ for this inscription. Given the nature of the evidence, any contextual interpretation of these inscriptions will rely on the interpretation of their entangled connections. Van Bremen's chronology and hypothesis of the Leon dossier is compelling and in this study I follow her argumentation.

24 I.Stratonikeia 19 may be Stratonikeia's recognition of the asylia; see also Debord (2001b), 32-33.

25 LaBuff (2016), 137-138 argues that the priesthood, with its prestige, would have been an end in itself for a powerful member of the elite such as Leon.

26 This is one of the main tenets of van Bremen (2004b). 
rule was at liberty to pursue her own agenda. Enhancing the sanctuary, while creating a Stratonikeian presence there, was an excellent means to connect to the communities in this area, creating a corridor of goodwill based on sacred ties through territory still held by Rhodes to the coastal areas. Eventually Stratonikeia did get access to the coast, through the polis of Keramos which was ceded to Stratonikeia through a territorial grant by Sulla in the Senatus consultum de Stratonicensibus, posted at Lagina after the Mithridatic wars. ${ }^{27}$

During the latter part of the second century and throughout the first century $\mathrm{BC}$, the link between the polis and the sanctuary grew tighter by the festivals that drew the population out towards the remote hilltop sanctuary. These aspects are discussed below, such as the inclusion of Hera, with a temple of her own, the priestly dedications to 'Zeus, Hera, and the demos', and perhaps the inclusion of the god of Panamara on the first coinage of the polis in the midsecond century $\mathrm{BC}$, although his image is very generic. ${ }^{28}$ The cult, however, had a relatively low profile in comparison with Hekate in the first part of the first century ВС, after the Mithridatic wars when the attention was firmly fixed on Lagina. The festivals for Zeus and Hera, the Komyria and Heraia, which were targeted at the entire population, citizens, foreigners, and slaves, may well have been going on in this period already.

A major turning point in thelife of the shrine came after the attack by Labienus and the Parthian troops in 39 вс. Unable to take the town, he desecrated the sanctuary of Hekate at Lagina and turned to do the same at Panamara. He apparently stormed the hilltop shrine during one of major festivals; the presence of the population outside the city walls would also explain the rationale and timing of the attack. Labienus was, however, thwarted by the miraculous intervention of Zeus, who protected the people of Stratonikeia and drove off the invading forces in a dramatic scenario worthy of Cecil B. DeMille. ${ }^{29}$ From this time on Zeus bore the toponymic epiklesis 'Panamaros', gradually replacing

$27 \quad$ I.Stratonikeia 505 , lines $54-58$.

28 These have also been interpreted to represent Zeus Chrysaoreus, see below under Civic Iconography.

29 I.Stratonikeia 10 tells the story of Zeus's epiphany at Panamara in an onslaught of three days and nights; this is discussed in more detail below under Urban Mediatization. An epiphany of an unidentified anax with Artemis, who together rescue a certain Pytheas, held hostage at Kindye, is told in the long poem of Hyssaldomos, son of Eirenaios. This remarkable inscription was found at Mylasa in the excavations of the proto-Maussolleion at Uzunyuva, and dates presumably from the later third or early second century вС; now published in Marek and Zingg (2018), with a discussion on who the anax, the saving deity or hero, may have been. On military epiphanies, see also Pritchett (1979), 1-46 (with a detailed summary of I.Stratonikeia 10), and Petridou (2016), Chapter 3 on siege epiphanies, esp. 134, 138-141 on Panamara. 
that of 'Karios'. As with Lagina forty years earlier, the event at the sanctuary was used by Stratonikeia to gain recognition and the grant of asylia from Rome through another senatus consultum..$^{30}$ This, together with the epiphany of the god that saved the city, was surely the rationale behind the third festival, the Panamareia. This took place in town, however, and like Hekate's kleidos agoge, the processions were centripetal, bringing the image of the god down from the hilltop sanctuary into the urban center.

Zeus's epiphany put Panamara on a par with Lagina, and Stratonikeia often minted both patron deities back to back on its coinage from this time on. The cult of Zeus Panamaros, like that of Hekate at Lagina, became more and more institutionalized within the urban realm of Stratonikeia. Even though Strabo seems to have been unaware of the hilltop god, Tacitus recorded Stratonikeia's presentation of 'Jupiter' and 'Trivia' as her two primary gods at the tribune of Tiberius in $23 \mathrm{AD}$, in which reforms were made in the privileges of asylia and cities had to state their case again. ${ }^{31}$

The relationship between the city and the sanctuary, which began to take shape in the second period BC, was obviously successful as it continued at least through the third century $\mathrm{AD}$, triggering the creativity of its community and even picking up new rituals such as the male dedications of locks of hair. The demise of the sanctuary is as obscure as its beginning. None of the published inscriptions date later than the fourth century. Laumonier believes an earthquake may have dealt the final blow, yet the sanctuary had been rebuilt after earthquakes before. More likely a change in interest lay at the root - a Byzantine chapel built from the ruins is recorded among the early investigations of the site..$^{32}$

\section{Data and Sources}

The primary source of information at Panamara are the inscriptions, over 400 of which were found already in the spring of 1886 by Gaston Deschamps and Georges Cousin; they described the hilltop as "white with stelai, as if it had snowed marble" (Figures 6.3 and 6.10). ${ }^{33}$ Over the following years

\footnotetext{
$30 \quad$ I.Stratonikeia 11-12 is the Senatus consultum de Panamara, from 15 August of 39 вс.

31 Tac. Ann. 3.62, quoted in Chapter 5 , note 61.

32 Deschamps and Cousin (1887), 374. An arch from a temple was also found with a cross engraved on it, I.Stratonikeia 168. Laumonier (1958), 222 and 225; see also below under Architecture.

33 A description of their travels in April 1886 is given in Radet (1901), 365-366. On p. 365: "S'ils ne recueillirent, durant le mois suivant, que la menue monnaie des explorations
} 


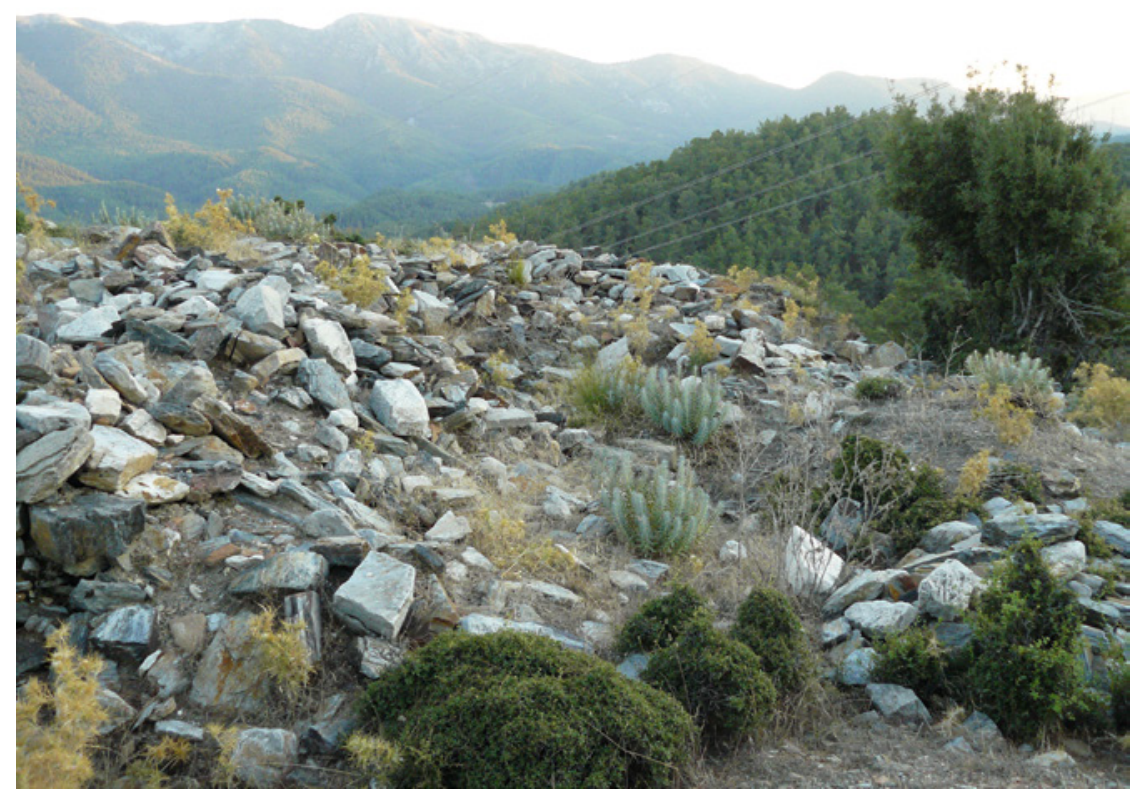

FIGURE 6.3 Panamara. Looking south towards the Gebeneadere valley, with several architectural fragments in the foreground; the Marçat Dağları is in the background

PHOTO AUTHOR 2010

they published many of the inscriptions in the Bulletin de Correspondance Hellénique. ${ }^{34}$ Jean Hatzfeld later visited the site and published the inscriptions which he found in $1927 .{ }^{35}$ Louis Robert stopped at Panamara in 1932, joined by

habituelles, à Baïaca, non loin de Stratonicée, un renseignement donné par le mouhktar, Hadji-Méhémet, leur procura une de ces surprises éclatantes comme il ne s'en était pas vu depuis Le Bas. Leur hôte turc leur ayant dit qu'une jonchée de 'pierres écrit' courronnait le sommet d'un pic voisin, ils escaladèrent le sentier sous sa conduite. Au faîte des rampes, une clairière apparut, toute blanc de stèles, comme si les marbres y eussent neigé. C'était le sanctuaire d'un dieu carien, Zeus Panamaros." The discovery of the 400 inscriptions among the ruins is first mentioned in Cousin and Deschamps (1887), 373ff.

34 E.g. Cousin and Deschamps (1887) on the senatus consultum, and Deschamps and Cousin (1887), on the sacerdotal family of Tiberius Flavius Aeneas; Deschamps and Cousin (1888a-c) on Marcus Sempronius Clemens, ex-votos, and hair dedications, respectively; Deschamps and Cousin (1891) on priesthoods and festivals; and Cousin (1904a) on honorific inscriptions for priests, and Cousin (1904b) on decrees; this collection was complemented by Holleaux (1904) and later. For an overview of the early investigations, see van Bremen (2008), 1406-1407.

Hatzfeld (1927). 


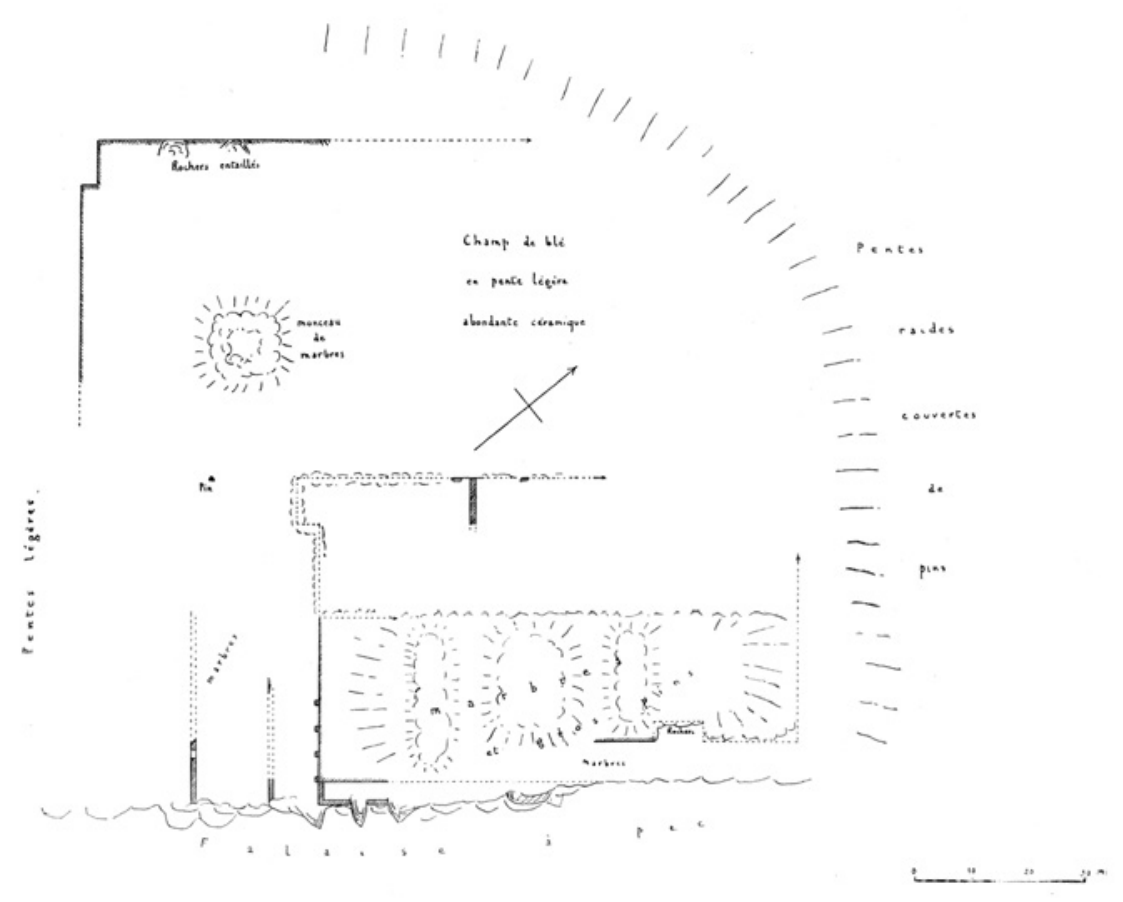

FIGURE 6.4 Sketch by A. Laumonier of the sanctuary at Panamara BCH 60 (1936), PLATE 41

Alfred Laumonier, who revisited the site on his own the next year, investigating the area and taking special notice of the walls. Laumonier published his report in 1936, and the sketch of the sanctuary that he was able to make is still the only plan we have of the site today (Figure 6.4). ${ }^{36}$ Although many wall sections are still in situ, and several architectural fragments and inscriptions that lie scattered across the surface (shown in the figures) bear witness to the centuries of intensive use, a thorough investigation of the hilltop and its context has yet to be conducted. Meanwhile, ongoing illegal diggings threaten the site, and many tombs are now exposed that Laumonier could not have seen in the 1930s (see Figures 6.24-6.26). The wider landscape of the sanctuary fares worse and much of it has already disappeared in the exploitation of lignite, or brown coal, by the Yatağan Power Plant and Güney Ege Linyitleri İşletmesi (GELİ) mining corporation. ${ }^{37}$

36 Laumonier (1936), 324-327, Pl. 41. His analyses of the priestly chronologies at Panamara were published Laumonier (1937) and (1938a).

37 See http://www.yatagantermik.com.tr/en/introduction/maden-direktorlugu. 
While the archaeology of the site has suffered from neglect and opportunists, the inscriptions on the contrary have received a good deal of scholarly attention, including by Alfred Laumonier, and later by Pierre Debord and Riet van Bremen. ${ }^{38}$ They have meanwhile been incorporated by Mehmet Çetin Şahin in the first and third volumes of his Inschriften von Stratonikeia..$^{39}$ Besides the inscriptions, the coinage of Stratonikeia and its depictions of Zeus Panamaros, as well as Hekate, provide another important source of information. Several of these were found in the Muğla hoard and have been re-examined by Andrew Meadows. ${ }^{40}$ Panamara is also now fortunately included in the new impulse of fieldwork in the area around Stratonikeia, under Bilal Söğüt, and Aytekin Büyüközer. ${ }^{41}$ Hopefully this will lead to new discoveries that will challenge the interpretations presented here, as well as promote further protection of the site.

\section{3}

\section{Environment of Panamara}

\subsection{Physical Environment}

Panamara is located nearly 10 kilometers southeast of Stratonikeia (Figures 6.1 and 6.7). The sanctuary is situated on top of a hill known as Asar Tepe, ${ }^{42}$ at a little over $700 \mathrm{~m} \mathrm{ASL}$, which forms the eastern end of a small ridge running southwest-northeast at the northeast end of the Gebeneadere valley (Figures 6.1, 6.5). The hilltop is defined on the northwest by a ravine that separates it from the highlands of the Bencik Dağları and the village of Bağyaka, now abandoned (Figure 6.7). Both ravine and valley empty into the Kapız river in the valley below the eastern side of the hilltop. Beyond the Kapız valley are the Koca Öküz hills which stand between Panamara and the wider Çine (Marsyas) valley (Figure 6.2). The southern side of the Gebeneadere valley is flanked by the Marçat mountains, which run more or less parallel with the Bencik Dağları northwest of the sanctuary. Panamara is thus nestled between the higher peaks of the Bencik and the Marçat ranges. The hills are largely covered in pine trees

38 Debord (2001b) and (2001a), 163-167; van Bremen (2003b), (2004b), and (2008); see also Merkelbach (1968); Drew-Bear and Schwertfeger (1979).

39 Inschriften griechischer Städte aus Kleinasien, Bd. 21 (1981) and Bd. 23 (2010), Bonn.

40 Meadows (2002). The Muğla hoard was initially published in von Aulock (1967); see also above, Chapter 5 , Data and sources.

41 See publications in the series Stratonikeia çalışmaları (2015-) edited by Bilal Söğüt.

42 Mutlu (2015). 


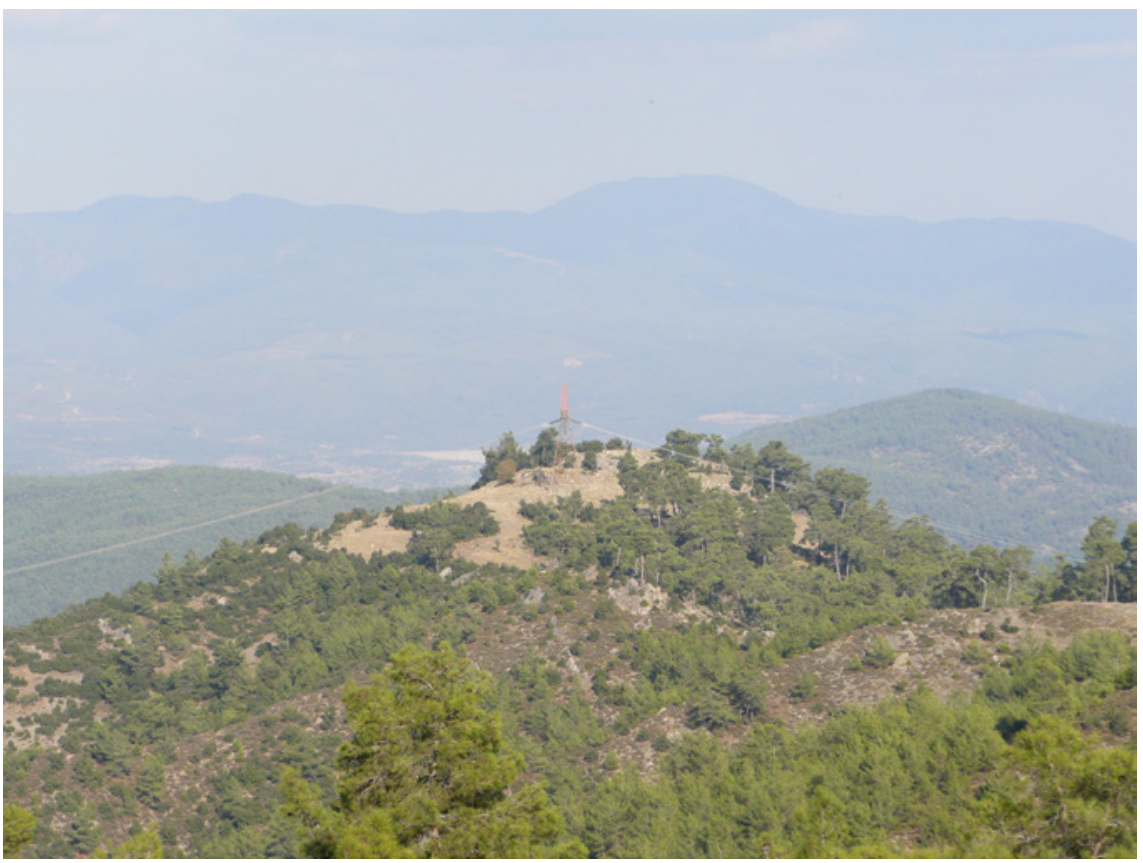

FIGURE 6.5 Panamara. View from the southwest; the sanctuary terraces and temple platform are visible at the top of the hill, to the right of the electricity mast Pното AUTHOR 2011

today, giving an impression of the sacred grove (alsos) that the shrine once possessed (Figure 6.5-6.6). ${ }^{43}$

The hilltop itself is formed of schist, which was used to construct many of the lesser walls within the sanctuary. Several outcrops dot the hillside, protruding in wall-like sections and aligned with the southwest-northeast axis of the length of the ridge. Perhaps these outcroppings, which sparkle in the late afternoon sun, as well as the strategic location, may help explain the location of the cult of this powerful deity on this hilltop.

As mentioned above, the area around Stratonikeia and Panamara is rich in lignite and is under exploitation through explosive strip mining. Although the village of Bağyaka was still inhabited in 2010 (Figure 6.7), in 2011 it had been evacuated, as was the community of Eskihisar at the site of Stratonikeia in the 1970s. The wealth of the natural resources in the area has led to the loss of the

43 The sacred grove at Panamara is mentioned in the Senatus consultum de Panamara as

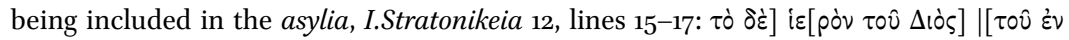






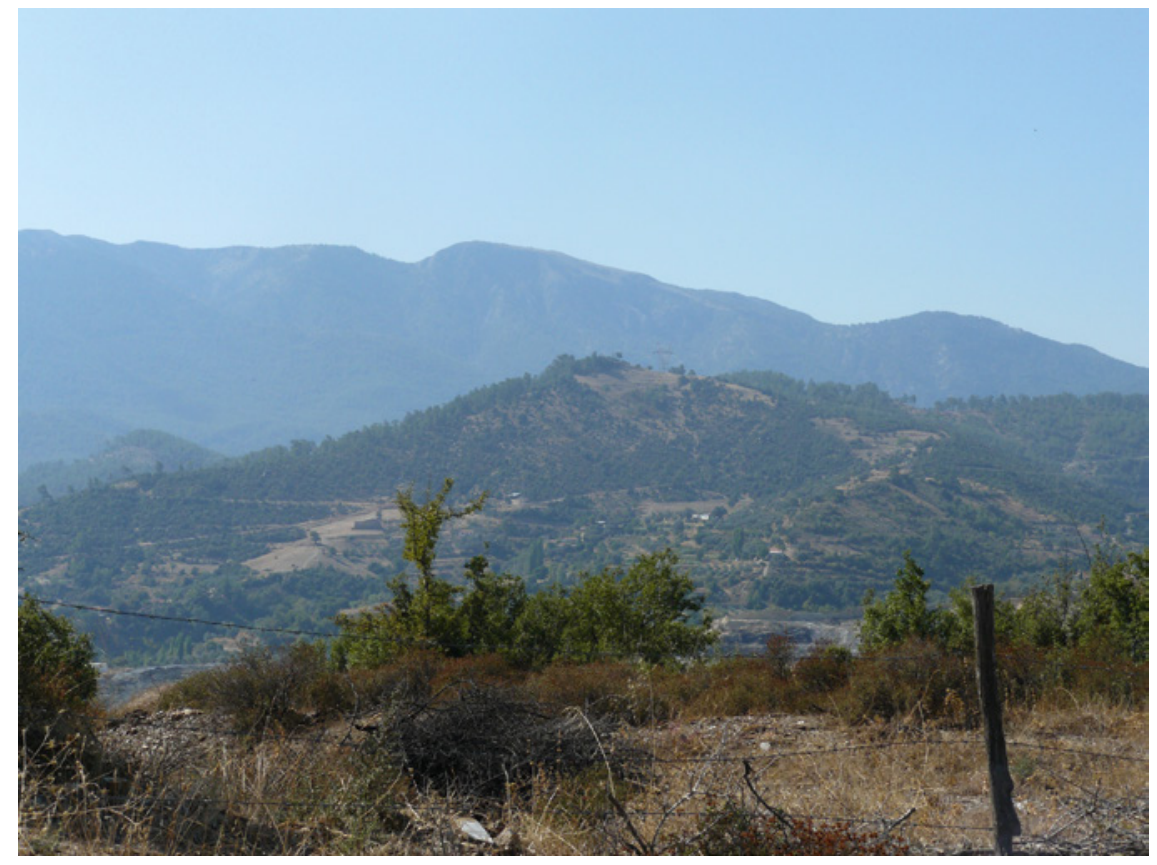

FIGURE 6.6 Panamara. Seen from the north, with the Marçat hills rising in the distance. The electricity mast just to the right of the top marks the northwest corner of the sanctuary PHOTO AUTHOR 2011

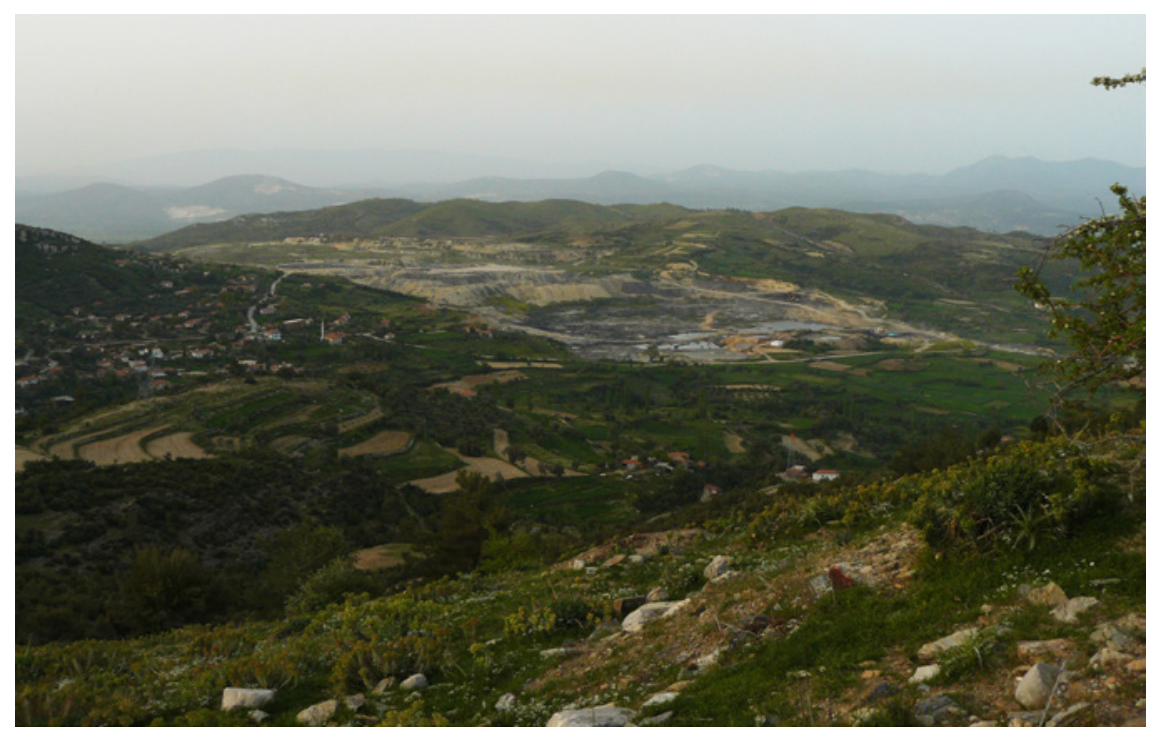

FIGURE 6.7 Panamara. View to the northeast showing the village of Bağyaka to the left before it was given over to the strip mines. The Madranbaba range is just visible in the distance 
archaeological surface record in the vicinity, making it a challenge to understand the integration of the sanctuary within the context of its landscape.

\subsection{Social-Geographical Location}

Panamara is located near the western edge of the Çine or Marsyas valley (Figures 6.1 and 6.2), the main north-south route which today connects Aydın (ancient Tralles) in the Maeander valley with Muğla in the valley and Gökova (ancient Idyma) in the Bay of Keramos, and other points south, via the D550 highway. In antiquity this valley would also have provided access to the towns of Alabanda, Stratonikeia, Pisye, and perhaps Mobolla. ${ }^{44}$ While not directly on this route, the sanctuary strategically oversees much of the surrounding area, as discussed below.

The sanctuary of Zeus Karios at Panamara was the center of the koinon, or community, of the Panamareis, perhaps located on the hill to the north, above Bağyaka, where Laumonier and Şahin each found traces of settlement activity. ${ }^{45}$ This community administered the sanctuary, through very differing political circumstances, until it was entirely absorbed by Stratonikeia. Van Bremen rightly states that "Panamara's location is a key to understanding its history" as the sanctuary is geographically more closely related to southern Karia than to central Karia. ${ }^{46}$ Southern Karia was for some time part of Rhodian territory and the position of Panamara at the edge of this social-political region is, in her view, a prime feature that attracted the interest of Stratonikeia. A number of southern communities were known to be involved with the cult of Zeus Karios at Panamara, prior to the ascension of the polis. The Leukoideis have tentatively been identified through some blocks with inscriptions found at the village of Çırpı in the Marçat mountains, roughly eight kilometers to the south; inscriptions concerning the Londeis were found a little farther to the southeast, at Çiftlik (Figure 6.1). ${ }^{47} \mathrm{~A}$ third community known to have been

44 Mobolla has been identified as the acropolis at modern Muğla, Radet (19o1), 366; Debord and Varinlioğlu (2001), 23-25; but see van Bremen (2004a), 375-377, who is skeptical of this attribution.

45 Laumonier (1936), 324-325, quoted below under Local Community. Şahin in I.Stratonikeia III, p. 13; the exact location, however, is not specified.

46 Van Bremen (2004b), 216.

47 Debord and Varinlioğlu (2001), 139-147 nos. $36^{-38}$ on Leukoideis at Çırpı, and 148-151 nos. 39-40 on Londeis at Çiftlik, where an inscription was found with the dedication of a fountain and nymphaion to Zeus Karios, perhaps of Panamara (no. 39); the map on p. 87 identifies the area between the Marçat mountains and the coast at Akbük as comprising the koinon of the Pisyetai and Pladaseis. See also the discussion on these communities below, under Administration and Priesthoods (in connection with the priesthood of Leon) and under Scope and Network. 
involved with the cult of Zeus at Panamara is that of the Laodikeis; they may have been located along the coast of the Gulf of Keramos, but their settlement has not been identified with any certainty. ${ }^{48}$ The town of Kallipolis, which also worshiped Zeus Karios at Panamara, is believed to be in the hills just across the Bay of Keramos. ${ }^{49}$

By promoting Zeus to one of the city's protective deities, Stratonikeia shifted the focus of the sanctuary north. The trace of the processional road connecting city to sanctuary, however, is largely unknown except for the section closest to the sanctuary, where it is tomb-lined and partly cut from the rock (see below). Alfred Laumonier was able to follow part of the road beyond this to the west, where he believed that it cut across the ravine at a shallower location, and then switched back east, skirting the hill near modern Bağyaka, and apparently connecting to the site which he found higher up on this hill. ${ }^{50}$ The path beyond this is unclear, although it probably crossed through much of the hill country to the north that is now being strip-mined. It is thus impossible with our present knowledge to say how much of a 'spatial continuum' there may have been between the sanctuary and the polis, or what other sites, features or monuments may have served as connecting nodes in between, except for the tombs closer to the sanctuary. ${ }^{51}$ The sanctuary may well have been located near a southern border of Stratonikeia, at least in the second century when the communities to the south appear to have been under Rhodian control.

Further to the west, the Bencik Dağı range eventually connects with the system of hills enclosing the eastern side of the sanctuary of Sinuri, c. 20 kilometers away. The Gebeneadere valley actually forms a kind of canyon-like corridor through the mountains in the direction of the sanctuary of Sinuri, within Mylasan territory; fieldwork would help determine whether there was a road here in antiquity. Yet despite the fact that the sanctuaries of these two deeply Karian gods, Sinuri and Zeus Karios, were contemporary, they were worshiped by distinct communities and no connection between the two is known to have existed. ${ }^{52}$

48 Debord and Varinlioğlu (2001), 212-216 no. 89 (= I.Stratonikeia 1402); on Laodikeia in Karia: Corsten (1995); Ma (1997), Reger (1998); van Bremen (2004a); Şahin in I.Stratonikeia III, p. 13, considers the settlement he discovered just north of the sanctuary as a candidate for Laodikeia.

49 Views on the more exact location of Kallipolis are discussed in I.Rhod.Per. p. 157.

50 Laumonier (1936), 325; the sacred road is discussed in more detail below.

51 On the 'spatial continuum' as a landscape of connecting features, rather than empty space, see Polinskaya (2006), discussed in Chapter 2.

52 The sanctuary at Panamara does however appear in a fragmented section from the thirdcentury decree from Labraunda, by the Chrysaoric League and Ptolemy II, I.Labraunda 44 , line 2 . 


\subsection{Visibility}

Panamara's exact situation regarding roads and local communities remains clouded, yet its position in the natural landscape certainly afforded a panoramic view that significantly expanded the visual reach of the polis. As with Lagina, there was no intervisibility between Panamara and Stratonikeia (see Figure 5.6, above). ${ }^{53}$ The countryside in between is very hilly, and the sacred road may have wound through various valleys along the way, as discussed below. Prominent and fortified as it was, the sanctuary would not have been visible upon approach from the polis until one reached the valley where Bağyaka is situated.

On a lower ridge at the end of the Gebeneadere valley between the Bencik Dağı and the Marçat Dağları, Panamara affords a good view to the west, extending to the peaks of the Gübremenladağ, 12 kilometers away (Figure 6.3). To the south, the settlement of the Leukoideis, at Çırpı in the Marçat, may have been visible, although the Londeis, at Çiftlik, were settled further to the southeast. Looking east, a stretch of the Marsyas valley can be seen near Bozarmut, although the Koca Öküz hills obscure much of the valley floor (Figures 6.86.9). Higher up on the eastern side, however, the Oyuklu mountain range is clearly visible. Panamara afforded good intervisibility with the ancient settlement of either Koraia or Lobolda, if this is located near Alaşar, as Debord suggests, ${ }^{54}$ although less so with the area suggested to be Londarga farther north. ${ }^{55}$ Some 40 kilometers well beyond to the northeast, the Madranbaba Dağları, near Hyllarima, crowns the horizon (Figure 6.7). The view north of the sanctuary is quickly met by the foothills of Bencik Dağı that extend to the west, although the peaks of the Gökbel range, beyond Lagina and the Hayırlidere valley, would be visible on a clear day.

Combined with the natural defensive features of the hilltop, the view was surely of strategic interest to Philip $\mathrm{V}$ and a reason to garrison his troops at the site in 201 BC. $^{56}$ This view would also have been important to Stratonikeia, who had little overview of such features as access routes, economic resources,

53 Figure 5.6 in the previous chapter combines the viewsheds of Stratonikeia, Lagina and Panamara.

54 Debord (1994); also Şahin in I.Stratonikeia III, p. 7 on the location of Koraia at Çatll, between Bozarmut and Alaşar, and p. 8 on Lobolda, for which he can offer no suggestions.

55 The identity of these settlements is discussed in Debord (1994) and Şahin in I.Stratonikeia III, p. 7-8, who suggests the site of Londarga, known from I.Stratonikeia 8, to be at the hill of Akçahisar just east of Kafaca (which is northeast of Lagina), where he saw the ruins of a temple and altar in 1973 .

56 Philip v's use of the sanctuary to station his troops is evident from I.Stratonikeia 3 and 4 , as mentioned above. 




FIGURE 6.8 Panamara. View from the steep east side of the sanctuary. The Koca Öküz hills are in the near foreground, with the Marsyas valley and the southern perimeter of Yatağan (east of Stratonikeia) visible just beyond. In the distance are the northern slopes of the Oyuklu hills РнОTO AUTHOR 2010

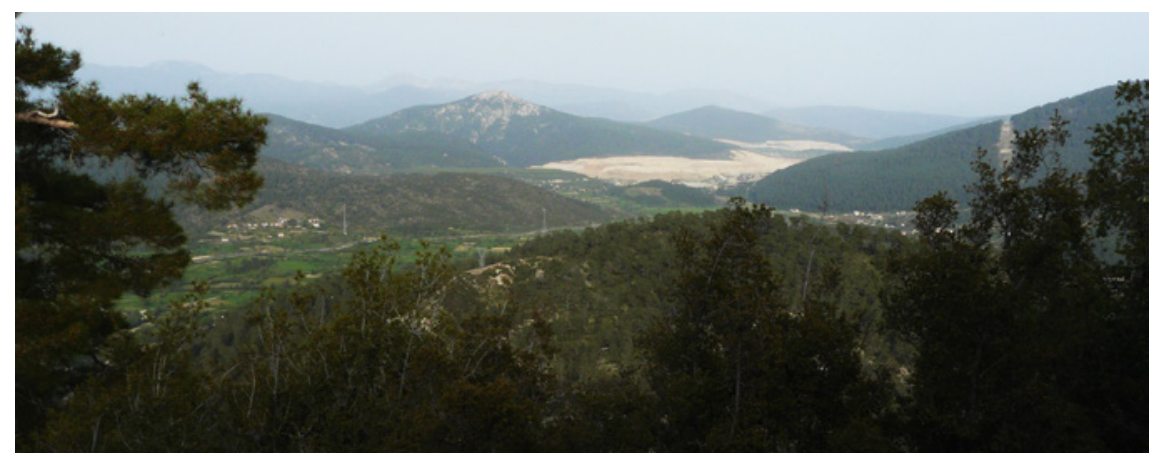

FIGURE 6.9 Panamara. View from the shrine towards the east-southeast. The southern extent of the Koca Öküz is visible in the foreground. The Marsyas valley is on the other side of these (not visible in the picture) with the Oyuklu hills beyond to the left in the far distance

PHOTO AUTHOR 2008 
and boundaries with neighboring communities to the south. Hidden from the urban center, these were prominent features within the viewsheds of Panamara and Lagina, and several were common to both - these sanctuaries thus greatly expanded the scope of vision for the polis. The viewsheds shown in Figure 5.6, in the previous chapter, show several areas of overlap: the Gökbel mountains to the north, the Madranbaba far away to the northeast, sections of the Marsyas valley, and especially the Oyuklu mountain range east of this valley, all areas that merit further scrutiny. This last area is of particular interest as these highlands offer a series of vantage points that encompass not only both sanctuaries, but the urban town center as well, all three of which were blocked from direct visual contact with one another. The settlement on the hill above Bağyaka may in fact have acted as a hinge, connecting the view towards Stratonikeia with the view over Panamara; ${ }^{57}$ this settlement was probably contemporary with the sanctuary, but has not yet been archaeologically investigated.

The overlap in the viewsheds of Lagina and Panamara, at 15 to 20 kilometers away, would not have been distinctive enough to identify specific features, but they clearly expanded the visual region of the polis to include among others much of this lower section of the Marsyas valley. ${ }^{58}$ The area would also have been understood to be Stratonikeian, due to the many associations already transmitted through coins, legends, festivals, the loud processions that must have reverberated through the valley, as well as the smoke rising from the sacrifices. Besides vision, all of the senses would have been engaged in acknowledging Stratonikeian presence in this part of the region; territorial shaping here was clearly accompanied by symbolic shaping through the use of cult, as will be discussed more in the next section on the urban integration of the cult into the polis.

\section{Signs of Urban Integration at Panamara}

The sanctuary of Zeus Karios underwent a number of changes as it was accommodated to suit the needs of the polis. Although the bulk of the information is provided by inscriptions, most of which date from the imperial period, there is nonetheless sufficient data to trace back many of the changes to the second and first centuries ВС as the cult changed hands from the koinon of the Panamareis to the polis of Stratonikeia. From a hilltop god worshiped

57 Laumonier (1936), 324-325, cited below under Local Community.

$5^{8}$ See Chapter 2 on visual regions. 
by dispersed communities in the wider parts of southern Karia, Zeus Karios became a poliad deity, focused on the people and politics of Stratonikeia to the north. This transition eventually had a profound impact on the nature of the cult and its community. The changes that took place, from the early involvement of Stratonikeia in the second century BC, and the potential of the cult regarding territorial expansion, through to the imperial period, show how the focus of the cult came to be fully fixed onto the polis and its social composition. By this period, Panamara had become a counterpart to Lagina through its institutions, and political use to gain external recognition, but especially to build social cohesion.

\subsection{Monumental and Ritual Space at Panamara}

Although the ruined state of the sanctuary leaves little to say about the use of concentric and linear space, there are nonetheless several indications that the sanctuary was heavily monumentalized with prestigious architecture (Figure 6.10). This trend was initiated by the koinon of the Panamareis, who administered the cult until the sanctuary was eventually absorbed by

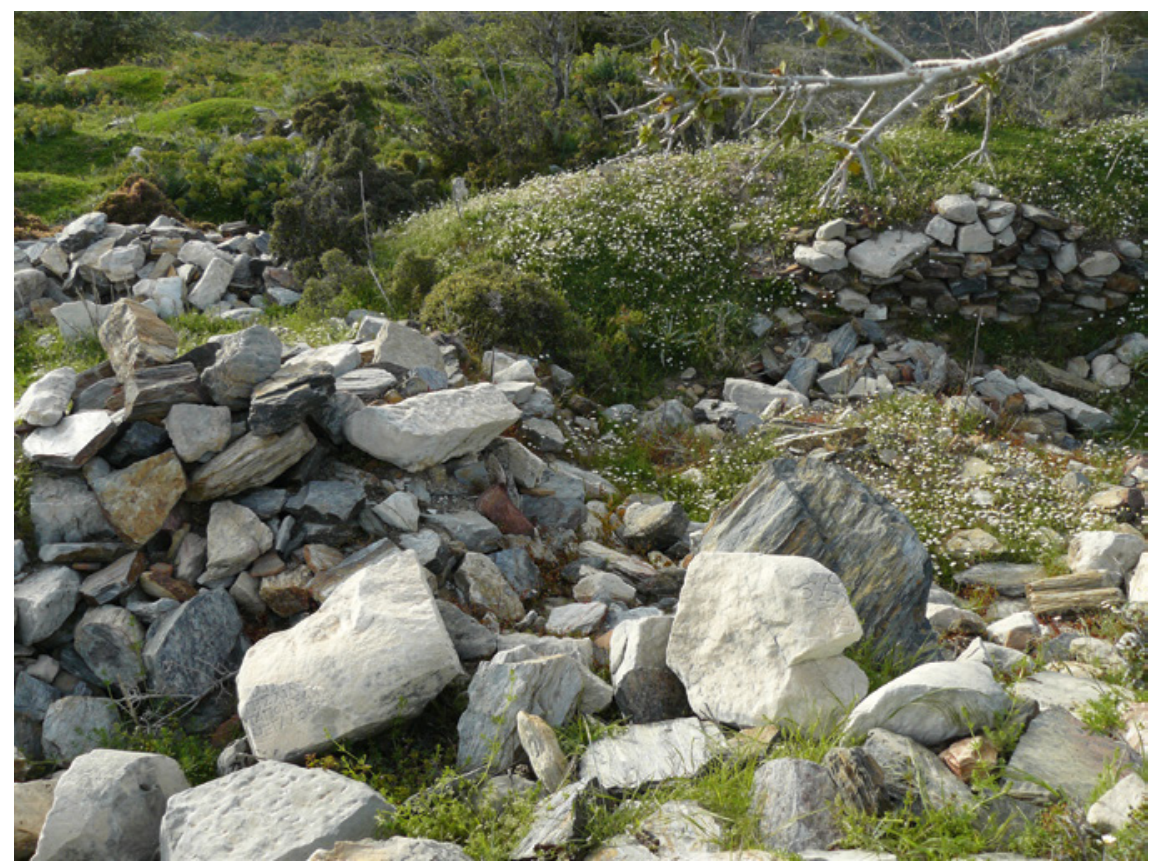

FIGURE 6.10 Panamara. View of the top showing schist walls with mounds of marble and schist blocks. The white marble block to the left in the foreground is a remaining fragment of I.Stratonikeia $257 \mathrm{~b}$, a priestly inscription from the later second century AD РнОTO AUTHOR 2008 
Stratonikeia. Inscriptions point to a major aggrandizement of ritual structures and facilities in the imperial period. The sacred way played an important role and shows some parallels with the sacred road from Mylasa to Labraunda.

\subsubsection{Architecture}

Panamara is described in the second century вс by the citizens of Kallipolis as 'the most prominent sanctuary', no doubt due to its location and regional festivals, but also its monumentality at the time. ${ }^{59}$ Although our appreciation of its architectural layout and development is heavily clouded, the sanctuary of Zeus is nonetheless assumed to have held at least one monumental temple and a bulwark of robust precinct walls by the end of the third century BC when Philip v occupied the sanctuary. Inscriptions mention a door jamb (parastas) which in all likelihood is from the temple, and the walls which were rebuilt after an earthquake. 60

Probably sometime after the hilltop sanctuary was absorbed by the polis, Hera was added to the cult and received a temple of her own, as is evident by the record of its attack by Labienus's troops in the first century вс. ${ }^{61}$ Since it was targeted separately, it was probably located at a distance from the temple of Zeus, perhaps in a more vulnerable spot, possibly near the cliff's edge as the attackers used ladders to get to it. ${ }^{62}$ Little else is known of the temples, although a comparison of architectural details with that of Lagina and Stratonikeia would surely give a better indication of their chronology and wider context within the building program of the polis.

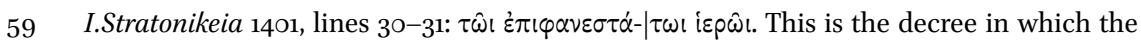
Kallipolitai praise Stratonikeia for appointing Leon to the sanctuary, discussed further below.

6o I.Stratonikeia 3 is an honorific decree for Philip v, dated to $201 \mathrm{BC}$; line 12 specifies that

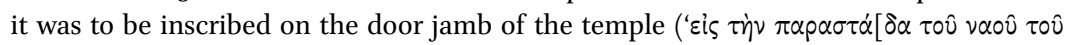
$\Delta(\grave{\varsigma} \varsigma)$, as the restored transcription indicates. I.Stratonikeia 4 is an honorific decree for Asklepiades of Peuma, appointed by Philip v as security commander of the place: [ $\dot{\alpha} \pi 0-$

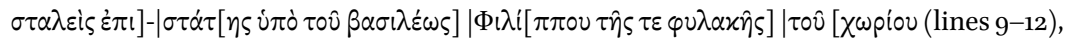



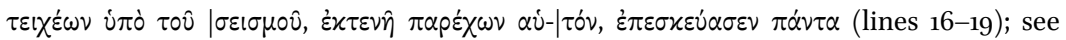
Holleaux (1904), 358-359, on earthquakes and warfare in the region. Van Bremen infers from these inscriptions that the temple and temenos wall must have existed even before the foundation of Stratonikeia in the third century BC, perhaps even going back to the fourth century BC; van Bremen (2004b), 215-216 and (2008), 1409-1411. The walls have not been subject to study but the sections now visible (Figures 6.10-6.14) give no indication of the header-and-stretcher technique characteristic of Hekatomnid construction of the fourth century вС.

$61 \quad$ I.Stratonikeia 10 , lines $25^{-26}$ mention the attack on the temple of Hera.

62 I.Stratonikeia 1o, line 28. 
Inscriptions, however, yield insight into the buildings, especially in the first centuries of the imperial period. One depicts the temple of Hera being 'dedicated' (anetheken) by a certain Posittos, son of Apellos, of Hierokome, who had served as priest but was now neokoros. ${ }^{63}$ More likely Posittos restored the temple (after the attacks?) since this is mentioned in a second inscription in the context of his construction and restoration of several other structures at the sanctuary, including a vaulted structure (psalis), porches (pastades), a safe for the key (kleidophylakion), two doorways worked with marble, and a marble enclosure (endomesis), another building (oikodomia) as well as supporting structures, a roof, and other features in wood - all of which were dedicated to Zeus Karios, Hera and the demos. ${ }^{64}$

Other structures known via inscriptions to have been erected on the hilltop or in the area in the imperial period include a shrine or altar to Artemis of Panamara and other deities, ${ }^{65}$ a third temple erected by Claudius Theophanes in the first century AD, which was associated with the imperial cult. ${ }^{66}$ There was also a fountain called 'Parthenike', ${ }^{67}$ different dining facilities (philotrophion, aristeterion), a magazine for storage (apotheke), as well as houses, stoas,

63 I.Stratonikeia 113 is the honorific decree for Posittos, for building and dedicating the tem-

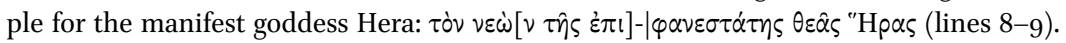
This inscription and I.Stratonikeia 112 are dated to the late first century вС or early first century AD.

64 I.Stratonikeia 112 is the building inscription, on an Ionic entablature, which Hatzfeld believed belonged to Hera's temple, Hatzfeld (1927), 79-81, no. 28, listing the many structures which he provided for the sanctuary, also in Laumonier (1958), 224. I.Stratonikeia

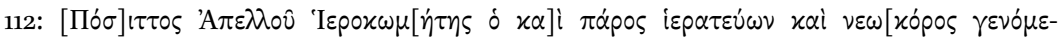

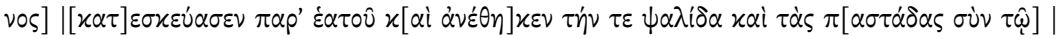

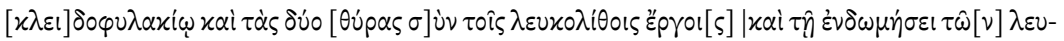

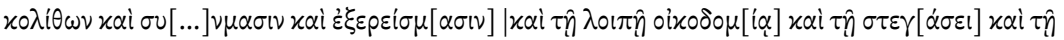

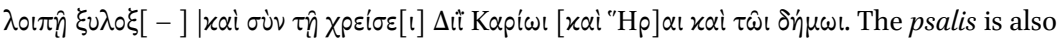
mentioned in I.Stratonikeia 17 , line 19, from the second or third century AD, in connection with a sleeping chamber (koiton). Later second and perhaps third century AD dedications inside the temple of Hera are mentioned in I.Stratonikeia 200 (plaster resurfacing, by priest Titus Flavius Aeneas) and I.Stratonikeia 281 (mosaic work in the naos and pronaos of the temple, by priest Kleoboulos), discussed in Laumonier (1958), 224.

65 I.Stratonikeia 251 speaks of a foundation or shrine for the cult of Artemis of Panamara, $\tau \hat{\eta} \varsigma$

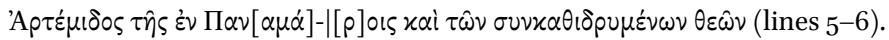

66 I.Stratonikeia 168 ; the dedication is reported in Hatzfeld $1927,82-83$, no. 31, to be on an arch which also bore a cross, the temple may have been converted into a chapel in the Byzantine period.


The fountain was dedicated by the priestly pair Flavius Eudemos Korazeus and Flavia Heraeis in the first century AD. 
workshops, and more. ${ }^{68}$ Places for spending the night in the area (kataluseis) are also mentioned in the later imperial period. ${ }^{69}$ One should also imagine non-permanent structures such as tents (skenai) which were known to be erected during the festivities, at least in the second century $\mathrm{AD},{ }^{70}$ along with the general areas for encampment (stratopeda).${ }^{71} \mathrm{All}$ in all, the image emerging from the epigraphic data is a well-known regional sanctuary that was increasingly outfitted with structures to accommodate a sizeable crowd over a period of days.

The complex at Panamara was obviously very impressive, even though little of its splendor is left to be seen on the hill south of Bağyaka. The sheer quantities of ceramics, including tableware, storage vessels, roof tiles, and architectural fragments, in marble but also local schist, as well as the many inscriptions that still lie scattered about, underscore the over six centuries of intensive use of this hilltop sanctuary. In 1933 Alfred Laumonier recorded several stretches of walls around the highest part of the hill at Panamara and interpreted them as the precinct walls of the temenos, enclosing an area of roughly $100 \times 85 \mathrm{~m}$ and oriented south-southwest by north-northeast (Figure 6.4)..$^{72}$ Many of these walls are still visible today (Figures 6.11-6.15).

Laumonier further identified the center of the sanctuary, and the temple, at the steep cliff at the eastern end, where several piles of marble blocks indicated

68 Philotrophion: I.Stratonikeia 267; aristeterion: I.Stratonikeia 17 and 270; apotheke: I.Stratonikeia 144; stoas: I.Stratonikeia 111 (also dedicating an ergasteria (workshop)), 226, 267 , and mentioned in 281 and 310 . See also Laumonier (1958), 224-226. A colorful, if fanciful, depiction is given in MacMullen (1981), 46-48, who laments the lack of academic attention given to the magnificent complex. I wholeheartedly agree.

69 Kataluseis, or lodgings, appear in I.Stratonikeia 248 , line 3, third century AD. Laumonier associates these with some ruins near the road in the Bağyaka valley, Laumonier (1936), 327 .

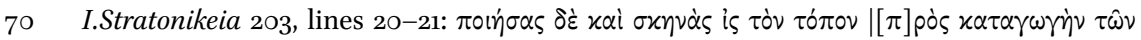
$\dot{\alpha} \nu \rho \omega \omega \dot{ } \pi \omega v$; dated to AD 164/166, the time of Marcus Aurelius. See also the skenas at Olympia, mentioned in the comedy Heniokhos PCG fr. 5. 7-8, used to accommodate the theoroi (with an intentional pun on the theatrical skene), quoted in Kowalzig (2007a), 41.

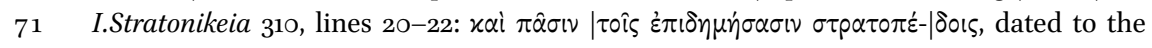
early fourth century AD.

72 Laumonier (1936), 324-327 on the description and layout of Panamara, with a sketch on Plate 41. The hilltop is extremely disturbed and although I discovered several sections of walls, I was unable to verify much of Laumonier's interpretation in my two short visits in 2008 and 2010. Since then several features have been exposed, including a number of schist walls, and especially the tombs discussed below. Laumonier's north arrow may also be off by a few degrees west compared with Google Earth, although the satellite images themselves are not accurately georeferenced for this area. Also, his measurements were probably taken on the ground crossing the steep hillside - an actual plan may appear narrower. 


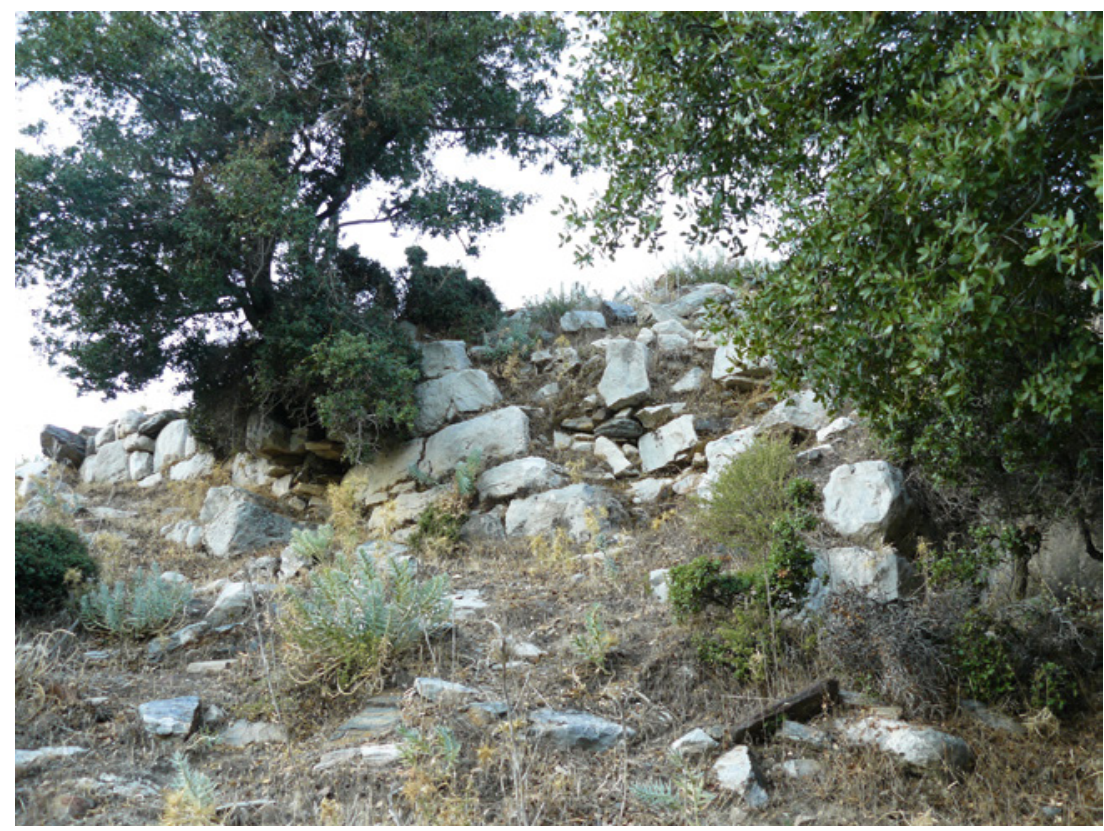

FIGURE 6.11 Panamara. Rustic orthogonal wall at the southwest corner of the temenos PHOTO AUTHOR 2010

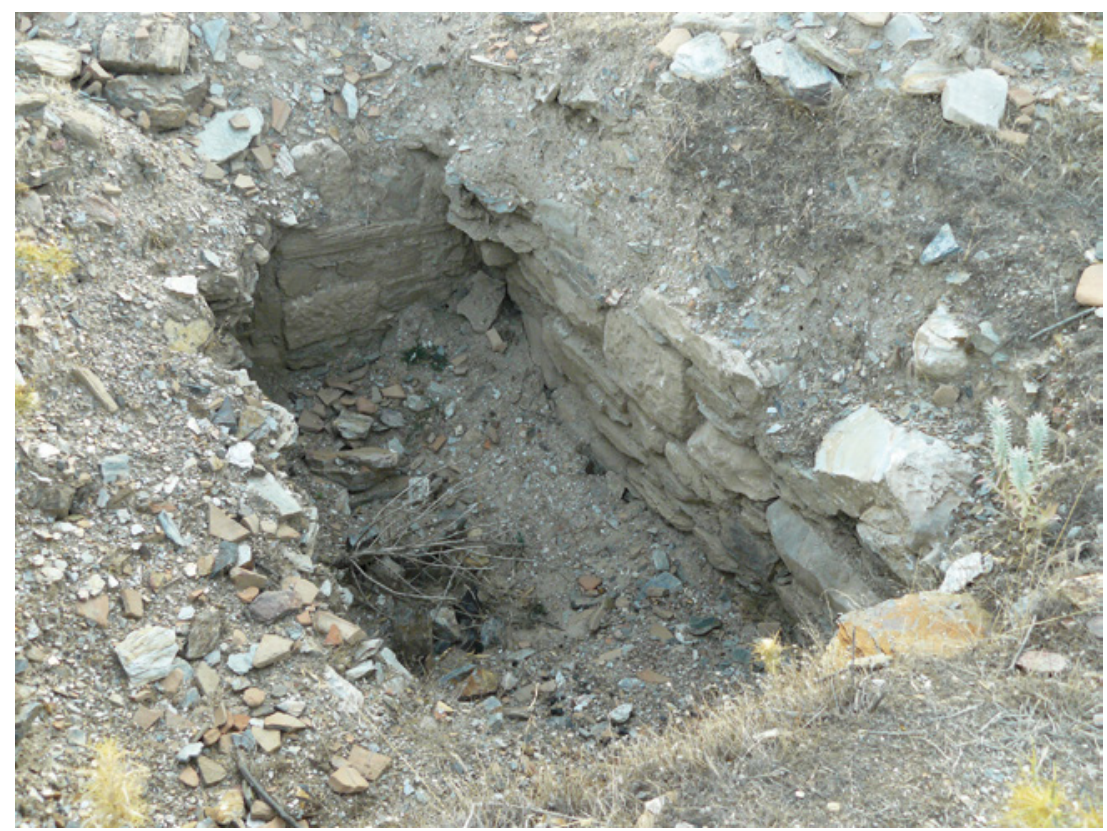

FIGURE 6.12 Panamara. Exposed schist and ashlar walls with fragments of amphora and tile РнОто AUTHOR 2010 


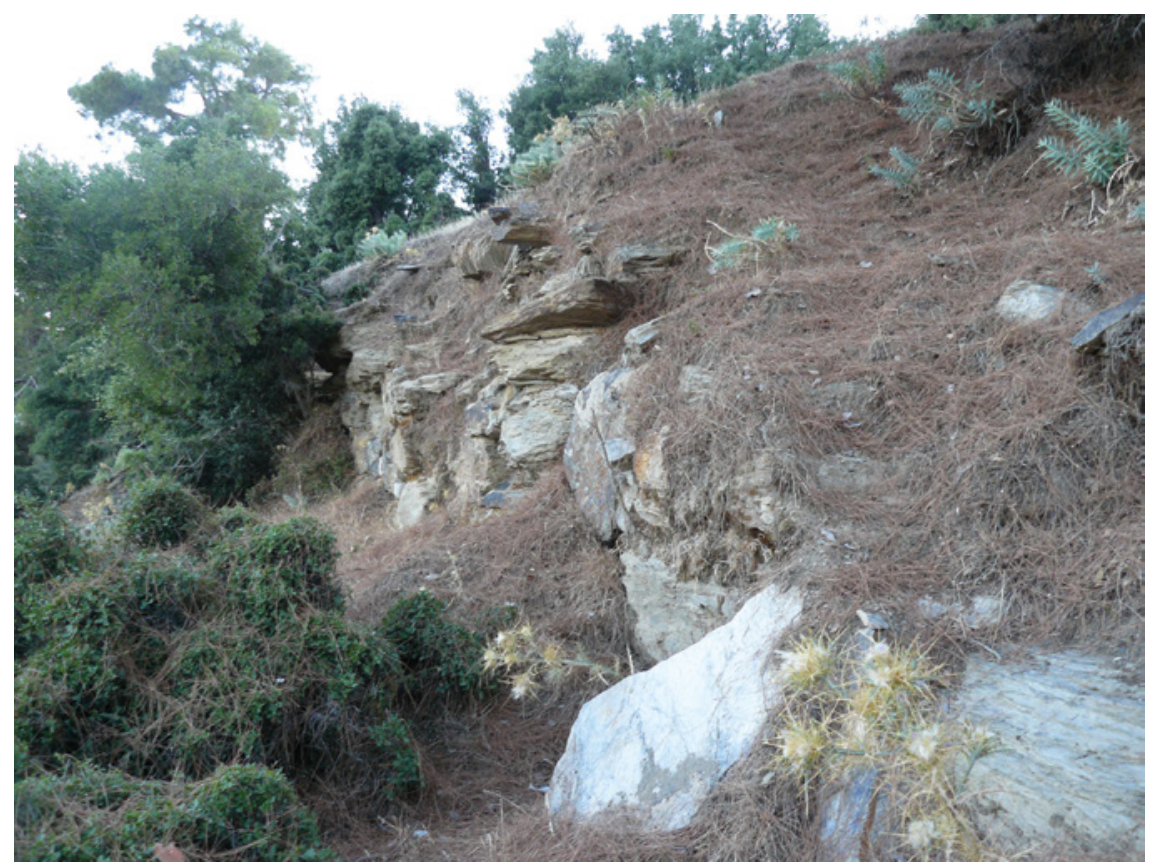

FIGURE 6.13 Panamara. Rock and schist wall along the northeastern perimeter PHOTO AUTHOR 2010

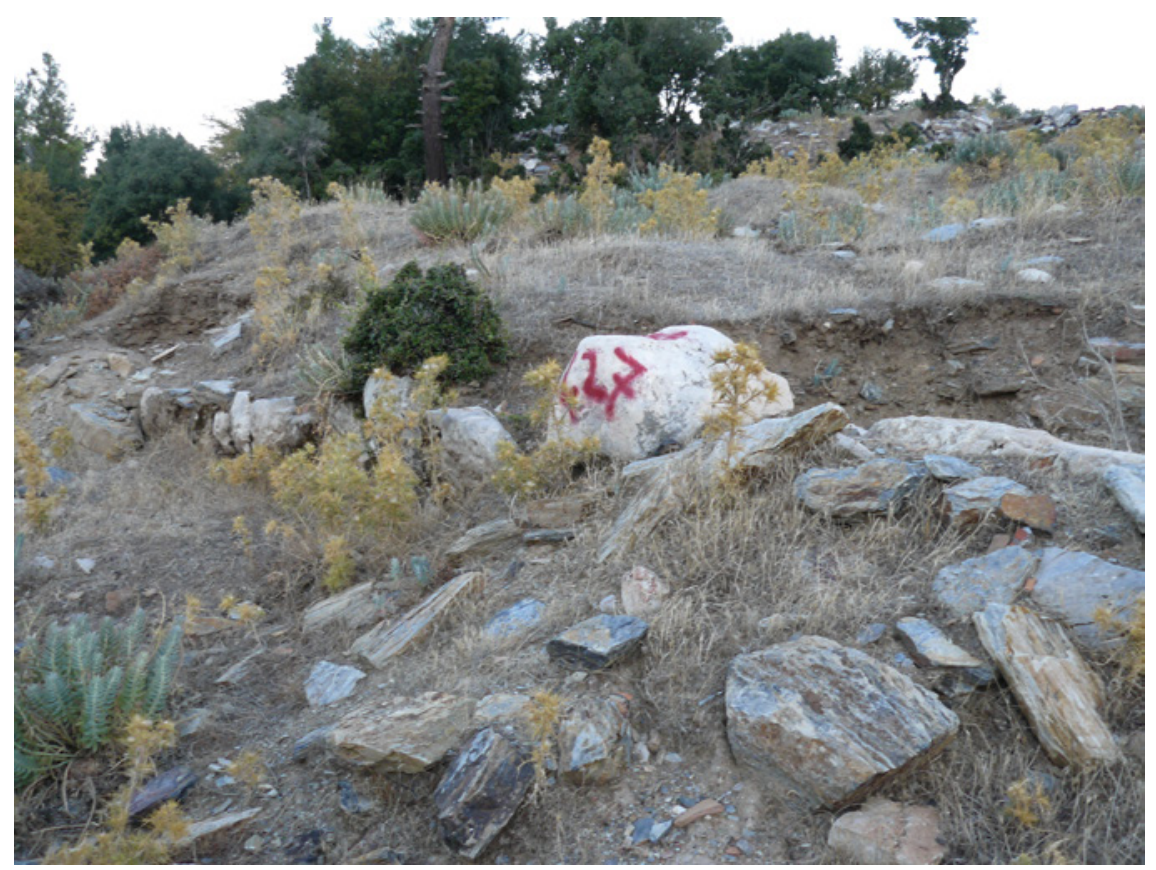

FIGURE 6.14 Panamara, north side. Exposed section of the north temenos wall PHOTO AUTHOR 2010 


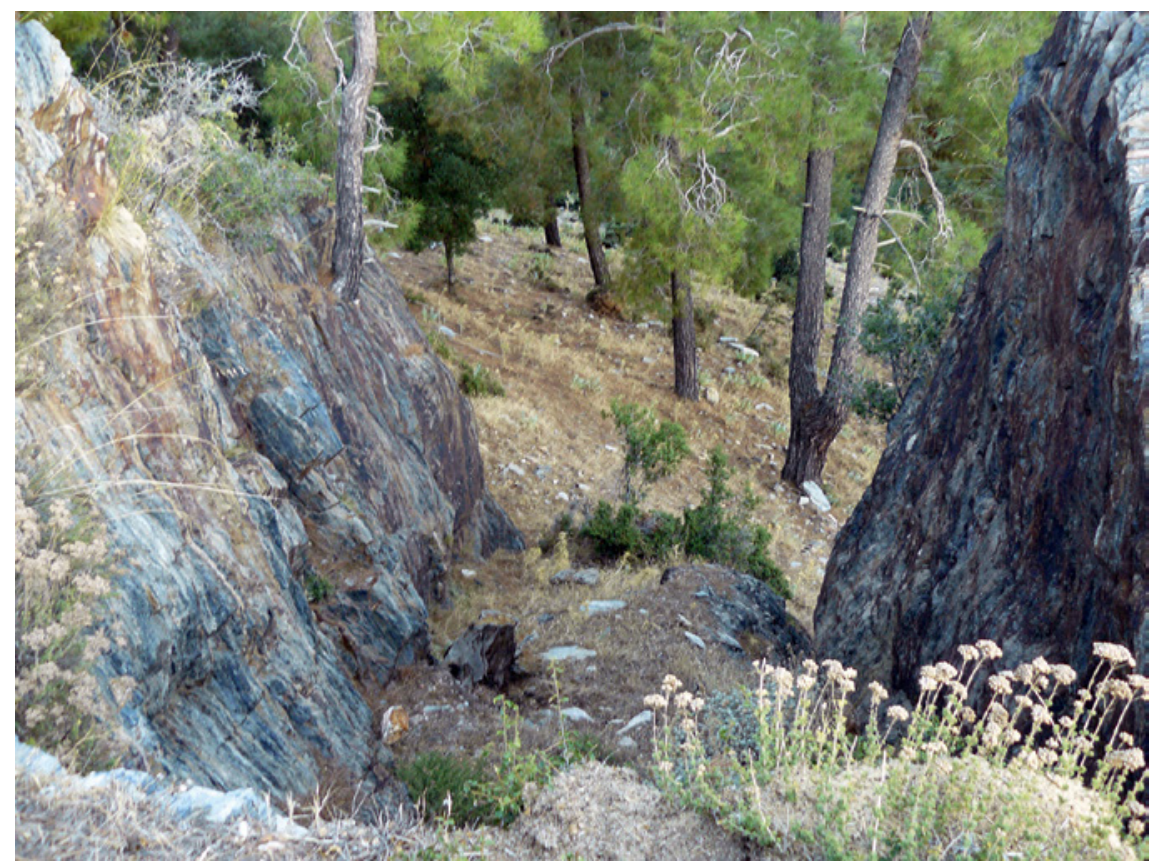

FIGURE 6.15 Panamara. Escarpment along the steep southeast edge of the hilltop PHOTO AUTHOR 2010

an elongated enclosure (Figures 6.16 and 6.17), stretching $50 \mathrm{~m}$ along the walls of the southeast escarpment. The thick outer wall on this side was adjoined by five 'contreforts', or buttresses, and Laumonier described the complex as having the appearance of a terraced fortress. ${ }^{73}$ In the western corner of the temenos was an isolated quadrangular structure, roughly $10 \mathrm{~m}$ long, with another pile of marble blocks which he tentatively identified as the altar. ${ }^{74}$ If this is the case, then the temples which he locates at the eastern end near the escarpment would have faced west, i.e. southwest, assuming they faced the altar. The level area just north of the complex, the 'champ de ble', or wheat field, open and free of stones, may well have been the gathering place for the processions, festivals, and games; this is at a natural point of access to the sanctuary from the sacred road (Figures 6.18-6.19).

73 Laumonier (1936), 325: “... l'ensemble du sanctuaire devait présenter l'apparence d'une forteresse à étages," see also Laumonier (1958), 223.

74 I.Stratonikeia $1413 \mathrm{~A}$ (=EA 41 (2008), no. 12A) is a fragmented inscription of a prohibition, which Şahin dates to the Hellenistic period and believes to come from the corner wall of a monumental "court-altar." 


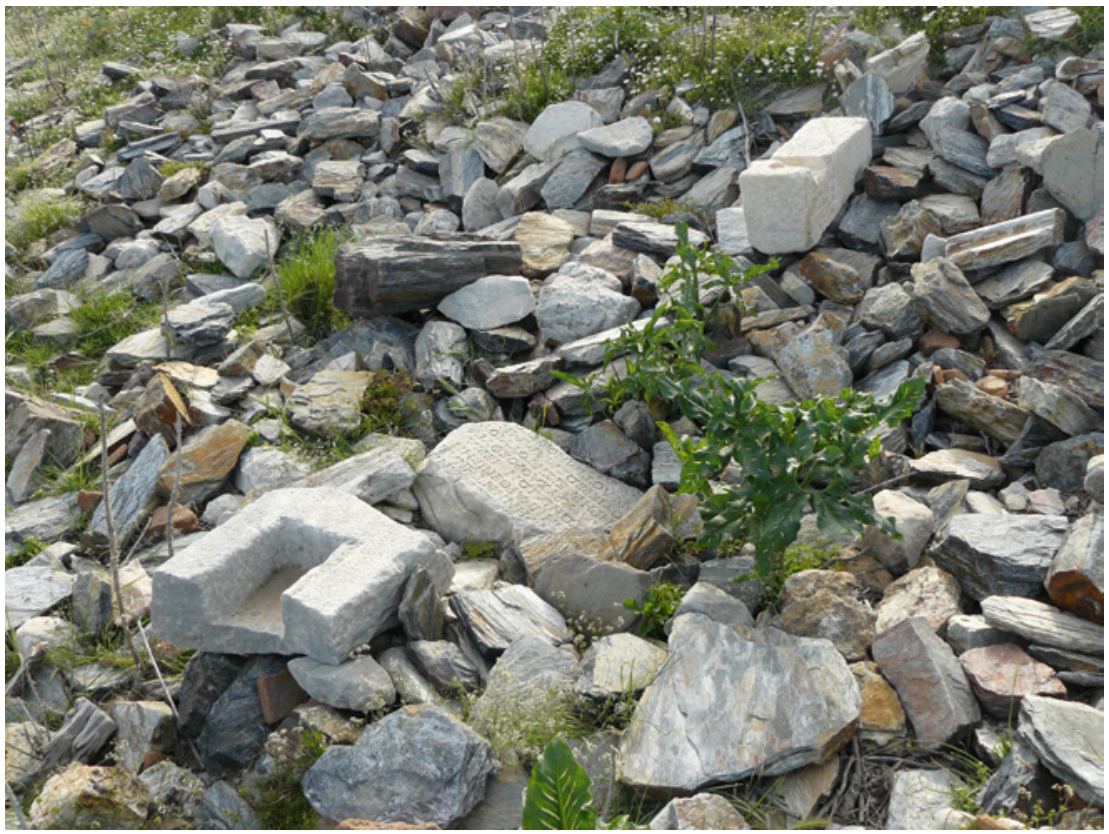

FIGURE 6.16 Panamara. Hilltop with scattered architectural fragments, ceramics, a coffer, and roughly in the center the lower part of the inscription I.Stratonikeia 220a, now further broken

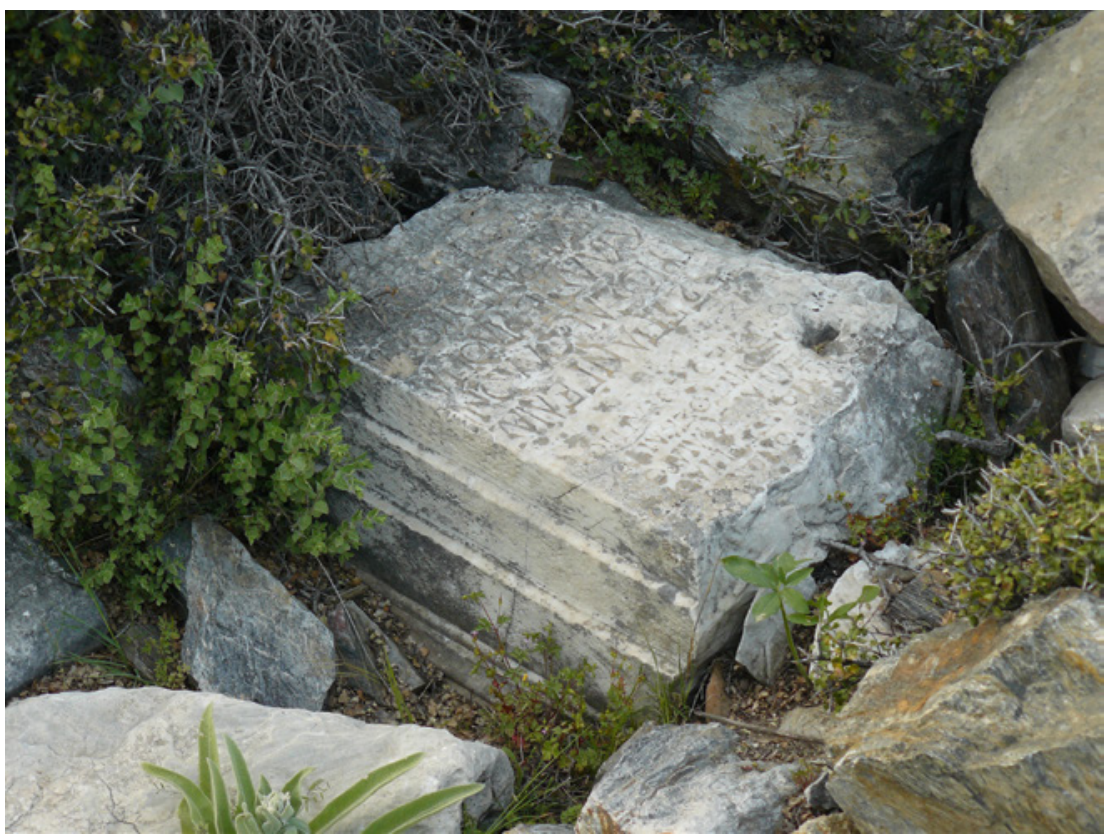

FIGURE 6.17 Panamara. Door jamb (?) fragment with two priestly inscriptions from the Imperial period, I.Stratonikeia 240 and 253, now broken at the top 


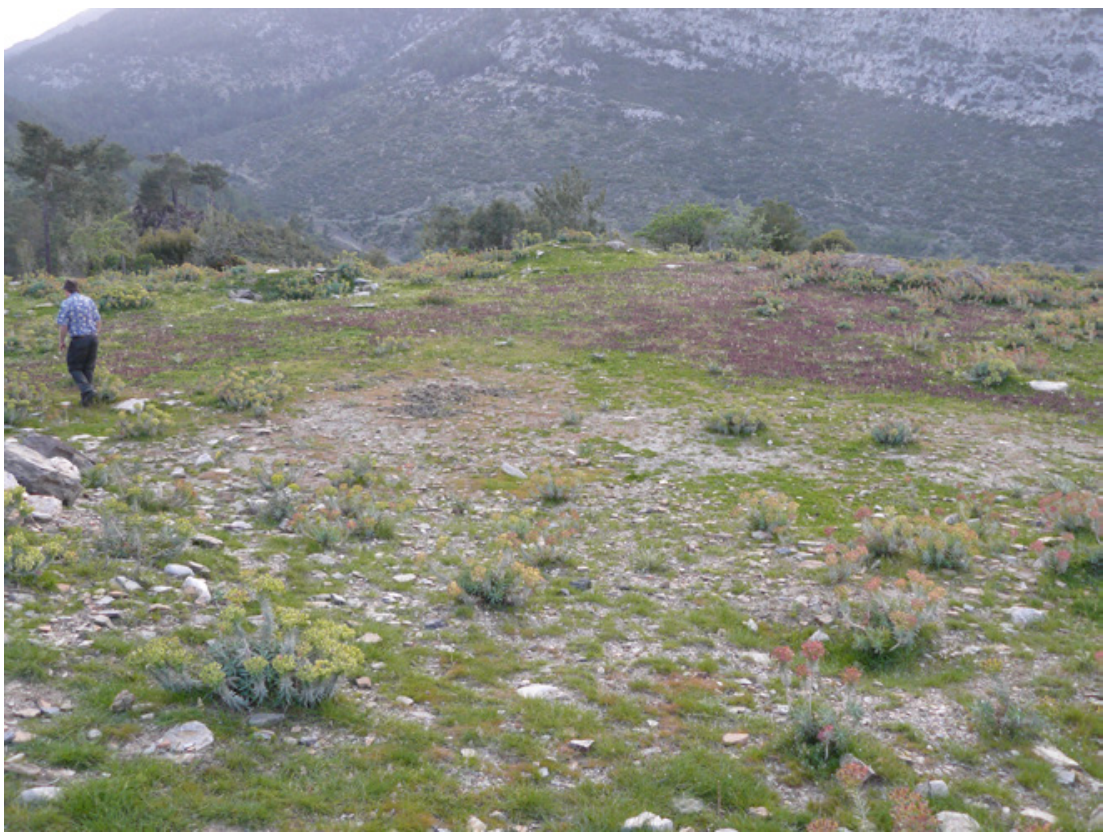

FIGURE 6.18 Panamara and the large terraced area at the northern part of the sanctuary. In the background is the Bencik Dağ PHOTO AUTHOR 2008

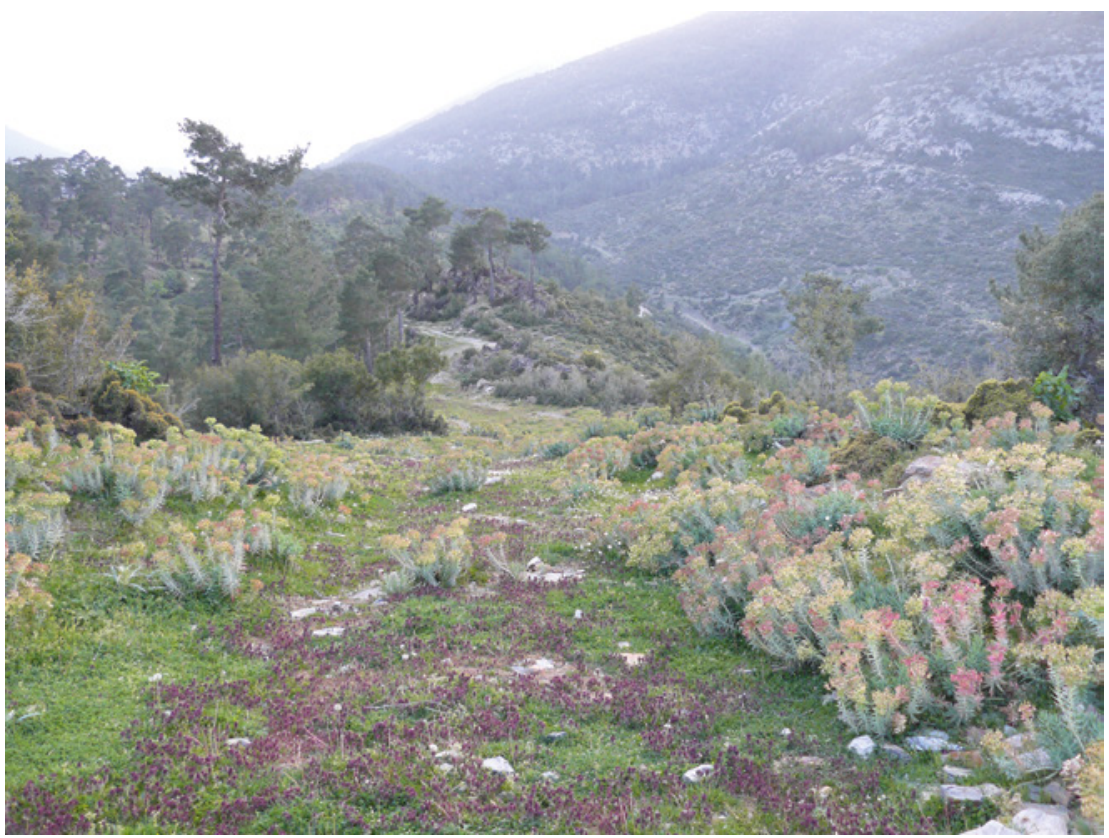

FIGURE 6.19 Panamara. Sacred road leading to the large terraced area PHOTO AUTHOR 2008 
Although a great deal of the sanctuary has been destroyed, the remaining rubble supports the picture given by the inscriptions of a gradual change at Panamara from a robust sanctuary built by a local community at a strategic site, to a grand urban complex with a number of temples in gleaming white marble. Even if the range of its visibility was not as extensive as that of Lagina, the marble temples perched at the eastern edge of the hilltop surely would have been a striking landmark, foregrounding Panamara in the mind's eye of the surrounding communities and especially of the Stratonikeians.

\subsubsection{Public Space - Concentric and Linear}

Due to the current state of the hilltop shrine, we can only speculate as to how public space was shaped and manipulated, with inscriptions as our best source. Laumonier's plan of the sanctuary gives a plausible location of the temenos walls and his identification of one or more temples near the eastern edge is probably correct, but beyond this it is difficult to label any other features with certainty; the 'monceau de marbres' on his plan (Figure 6.4) may well have been an altar, as he suggests, but it could also be the remains of one of the many other structures that are known to have existed at the sanctuary. The site today is unfortunately much more disturbed than when he visited it in the 1930s, precluding any further interpretations based on informal surface investigations. The space at Panamara may or may not have been as clearly articulated as at Lagina, but the number of structures, at least in the imperial period, imply that it was just as well equipped, if not better. Rather than being designed at once, however, inscriptions inform us that the sanctuary developed over time and we can only assume that the additional temples, and especially the stoas or other enclosures (e.g. endomesis, philotrophion), and other structures were arranged to create some kind of logical internal area that would have worked as a concentric space for the whole population of the Stratonikeians, who regularly came out to the festivals at the sanctuary. The sacrifices would surely have formed a focal point, as well as the mysteries that appear in inscriptions from the late second or third centuries AD. ${ }^{75}$

Whether linear space was visually put to work through 'framing' or emphasizing sightlines, or the extent to which the view from the sanctuary was employed in its spatial arrangement, as at Labraunda or Lagina, is impossible to say with the present state of knowledge. Linear space was however used to

\footnotetext{
75 Panamara may well have possessed some arrangement for spectators, as assumed in Nielsen (2002), 139, although there is no evidence of a theatron. On the mysteries at Panamara, see below under Festivals and Administration and Priesthoods for the position of the mystagogos.
} 
physically connect the sanctuary to the city through the processional route known from the epigraphic evidence. ${ }^{76}$

\subsubsection{Sacred Road}

The sacred road leading from Stratonikeia would have passed through one of the city gates, probably in the southern flank of the city wall. The rest of its course through the hills is unknown, although if it took the shortest route it would have passed through the valley now exploited for brown coal. Figure 6.1 at the start of this chapter shows a possible trajectory of the processional route that connected the shrine with the urban center. The last section of the road is more secure. Some stretches leading to the sanctuary were discovered by Laumonier during his travels in $1933 .{ }^{77}$ One section, roughly three meters wide, continued for over a half a kilometer close to the ravine that separates the hilltop from the Bencik mountain to the northwest. The sacred road may have passed first along the north side of the ravine near Bağyaka, continuing southwest until it could be crossed. From here it switched back towards the northeast, climbing up at a gentler angle to the hilltop and to the heart of the sanctuary.

Parts of it were terraced, as may be seen in Figure 6.20, other parts were cut from the rock to facilitate smooth passage. At the lower part of the hill are some tombs and perhaps some structures cut from schist that might indicate some kind of occupation - possibly some of the ruins that Laumonier saw lining the road to Bağyaka (Figure 6.1). ${ }^{78}$

The sacred road thus approached the sanctuary from the western side, following the northern crest of the hill (Figures 6.20-6.23). As at Labraunda, tombs lined the section close to the shrine, cut into the rock and occasionally built up (Figures 6.24-6.25). Although we may never know their exact chronology or to whom they belonged - whether these were local residents, the Stratonikeians from town, or perhaps even the earlier Panamareis - they are an additional testimony to the sanctity of the site and its thorough integration with the community. ${ }^{79}$ On the western side of the hill very close to the sanctuary, and just south of the open terraced area, is a large electricity mast. The construction work for this may have been what initially exposed several marble blocks in situ, but illicit excavations in the following years exposed a doorway

76 The procession is described for example in I.Stratonikeia 266 ; see below.

77 Laumonier (1936), 325, in which he describes traces of a road he tracked from an ancient settlement on the hills above and west of Bağyaka. This is discussed in detail below, under Local Community.

78 Laumonier (1936), 327, suggesting these may have belonged to the 'lodgings' mentioned in I.Stratonikeia 248.

79 See further below under Local Community. 


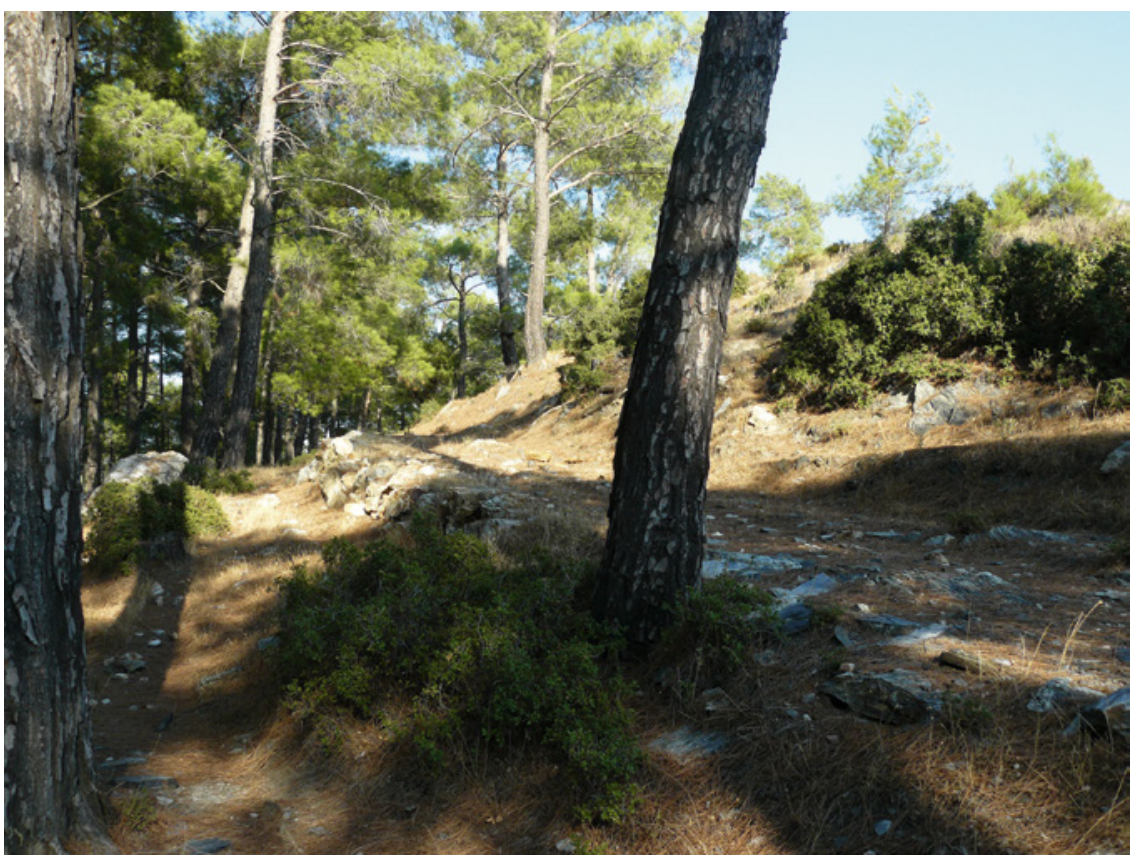

FIGURE 6.20 Panamara. Section of the road, partly terraced as shown here, roughly one kilometer southwest of the sanctuary PHOTO AUTHOR 2011

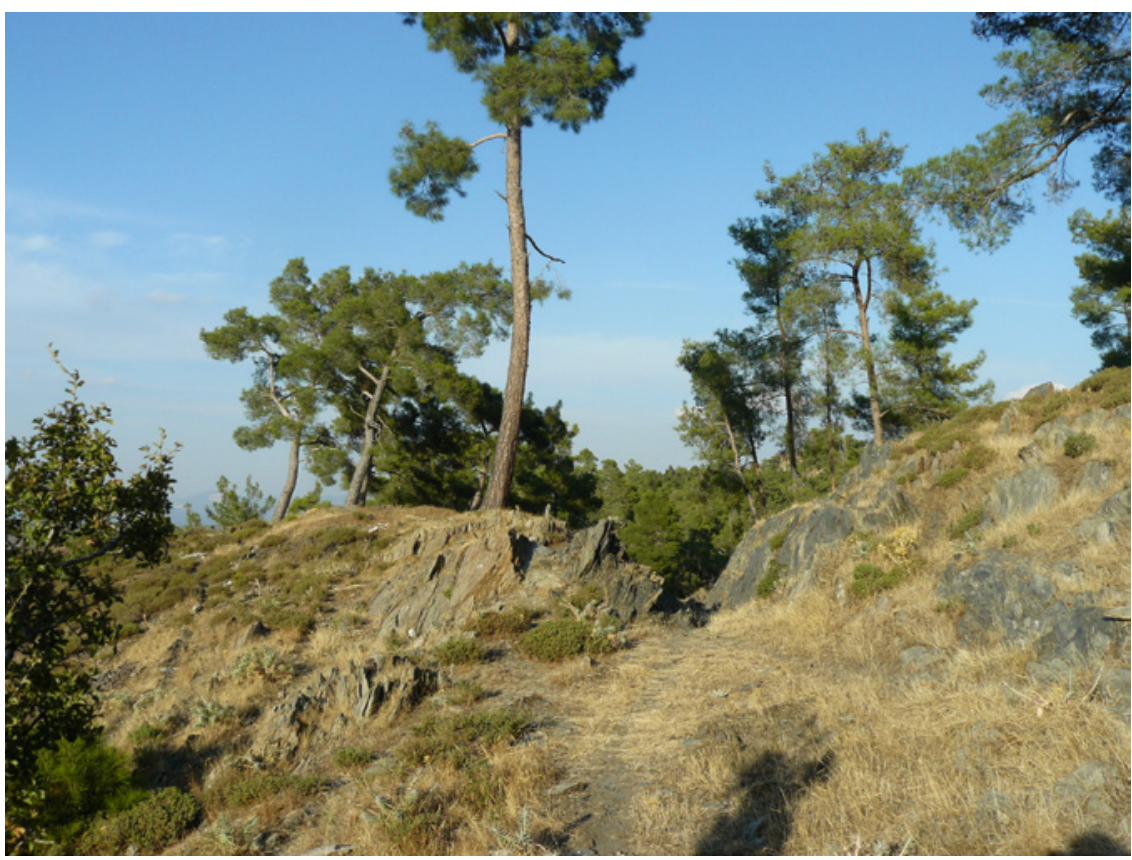

FIGURE 6.21 Panamara. Sections of the sacred way southwest of the sanctuary cut through the rock 


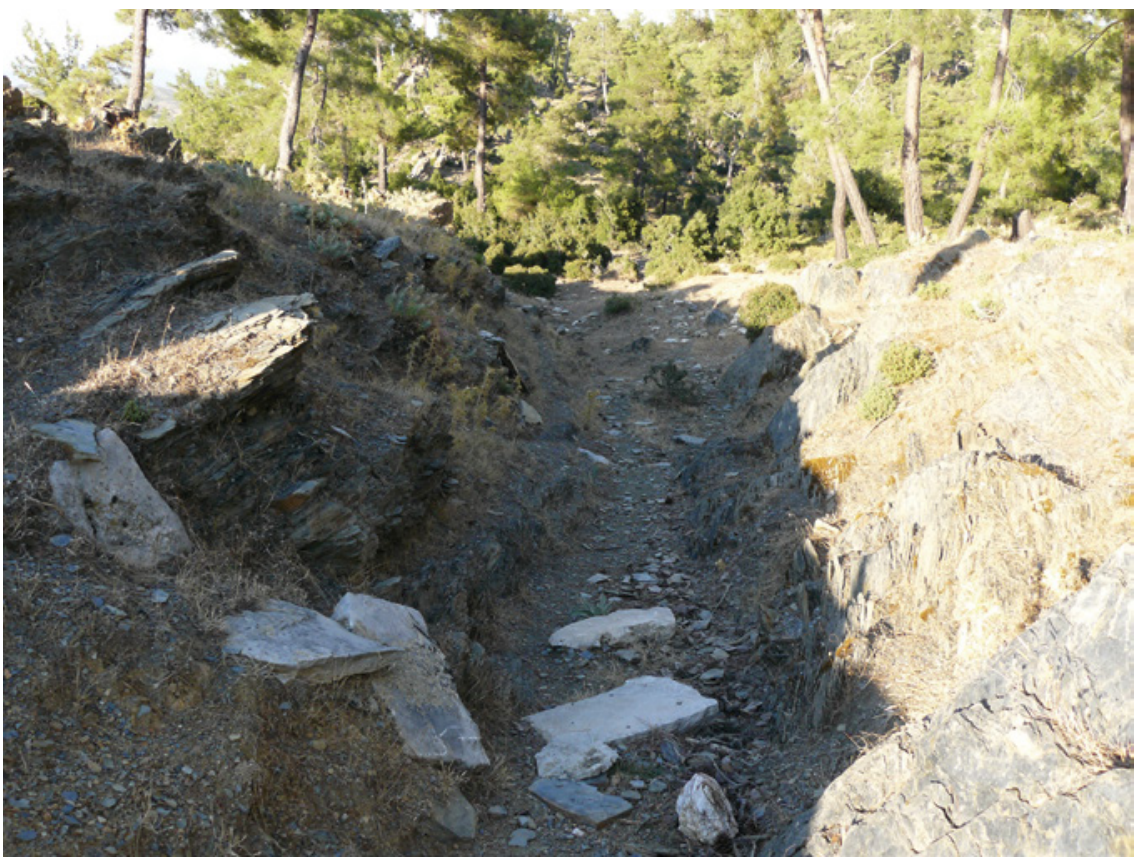

FIGURE 6.22 Panamara. Sections of the sacred way, cut through the rock РнотO AUTHOR 2010

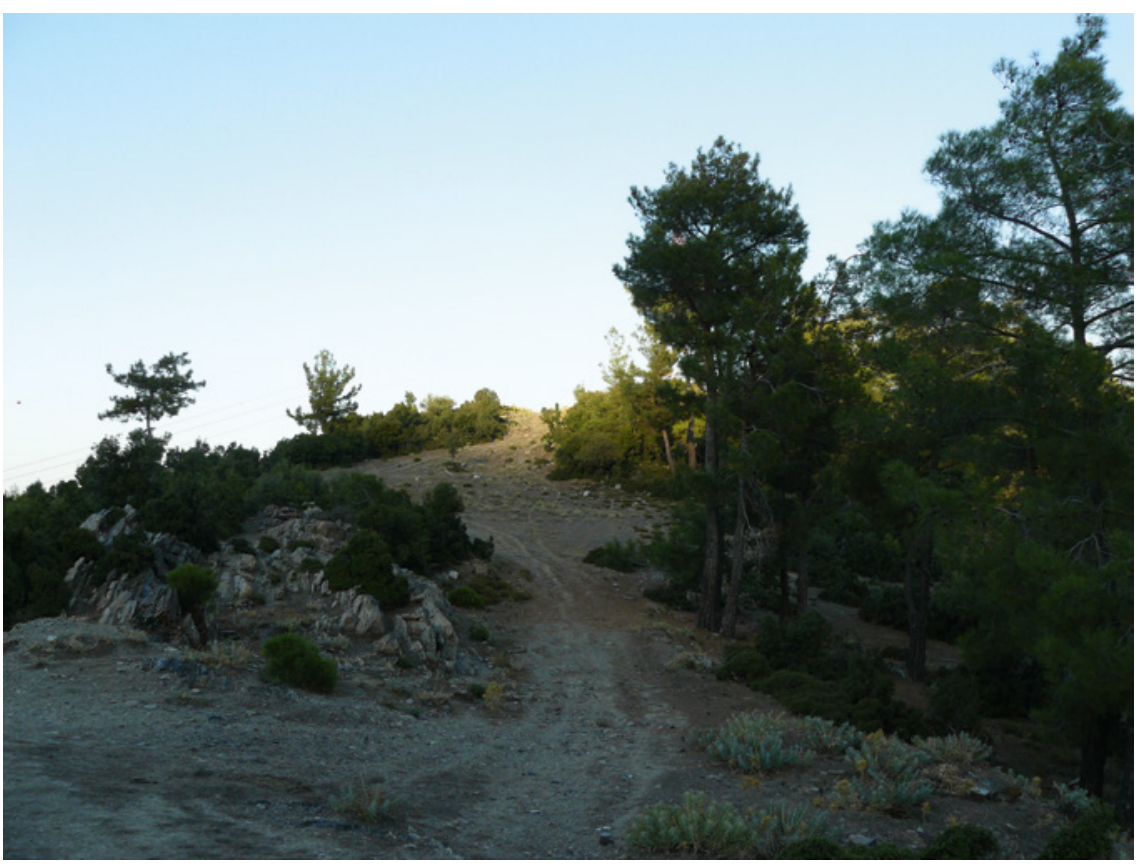

FIGURE 6.23 Panamara. Sections of the sacred way west of the sanctuary PHOTOS AUTHOR 2010 


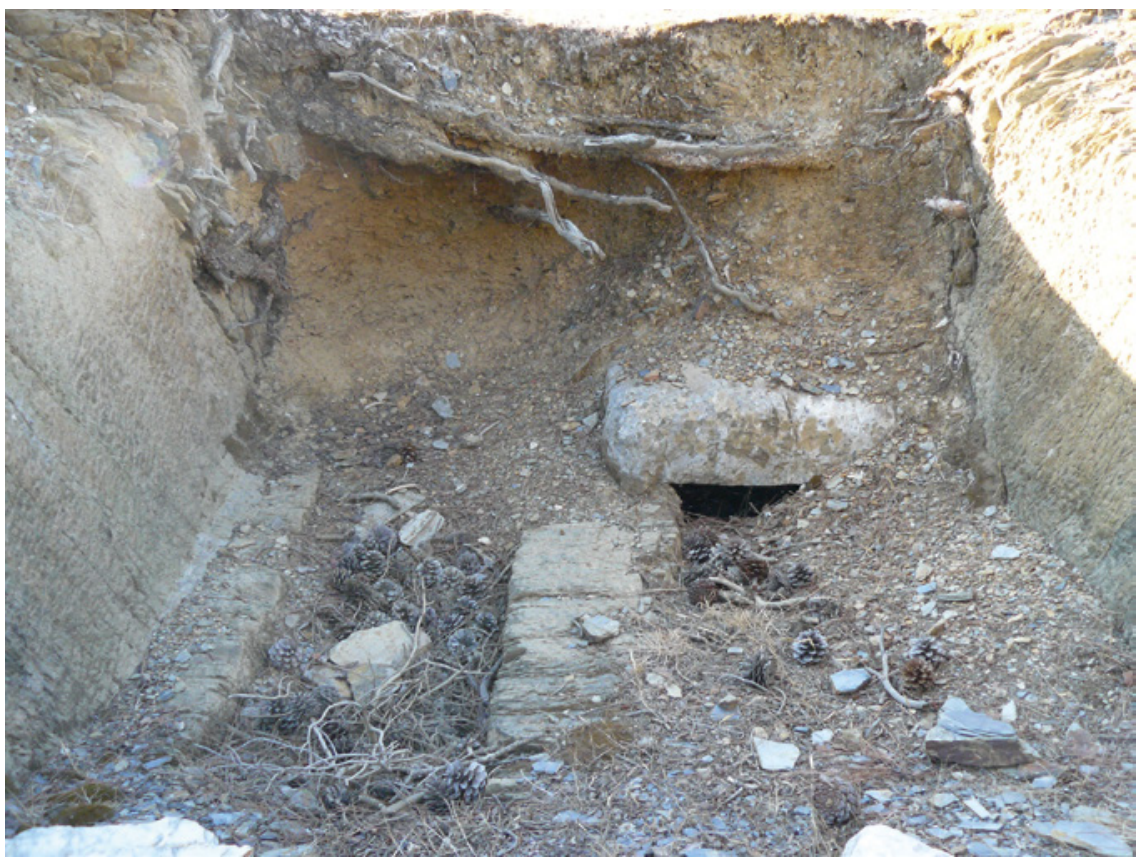

FIGURE 6.24 Panamara. Built tomb along the sacred road near the sanctuary PHOTO AUTHOR 2010

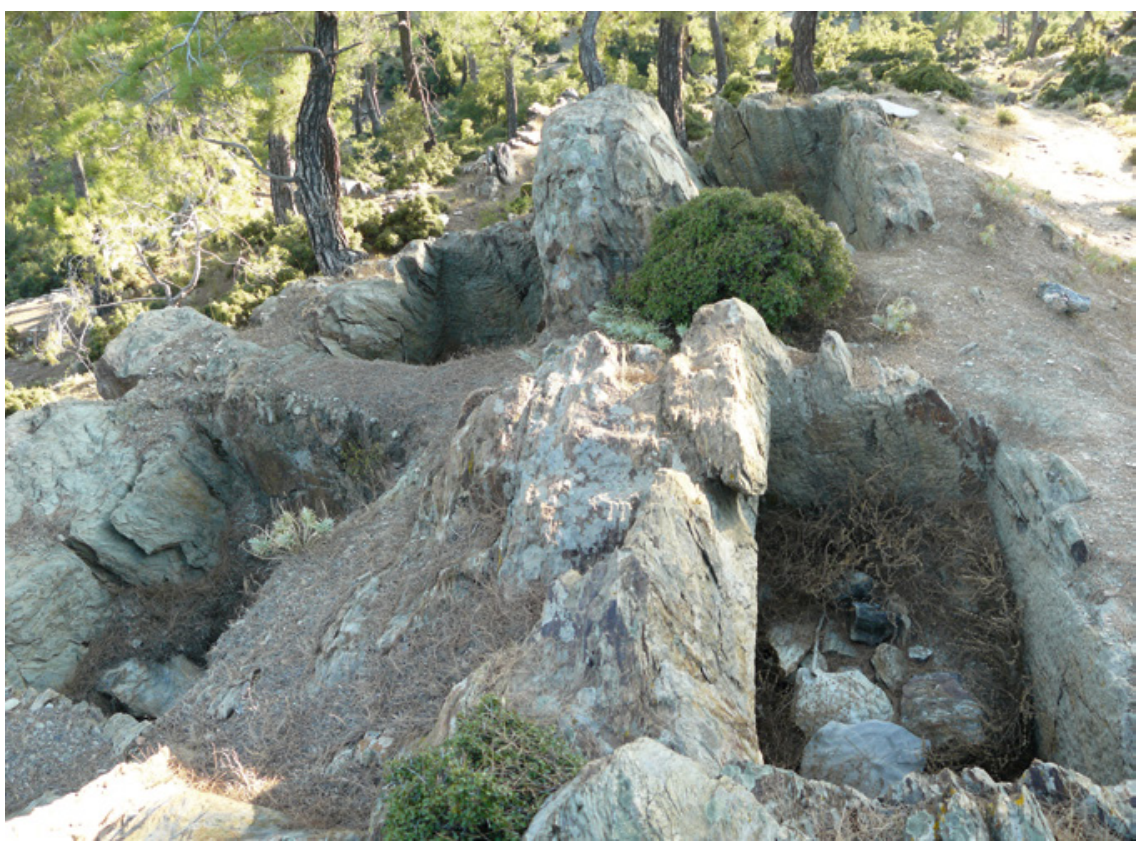

FIGURE 6.25 Panamara. Four adjacent rock-cut tombs along the sacred road west of the sanctuary 


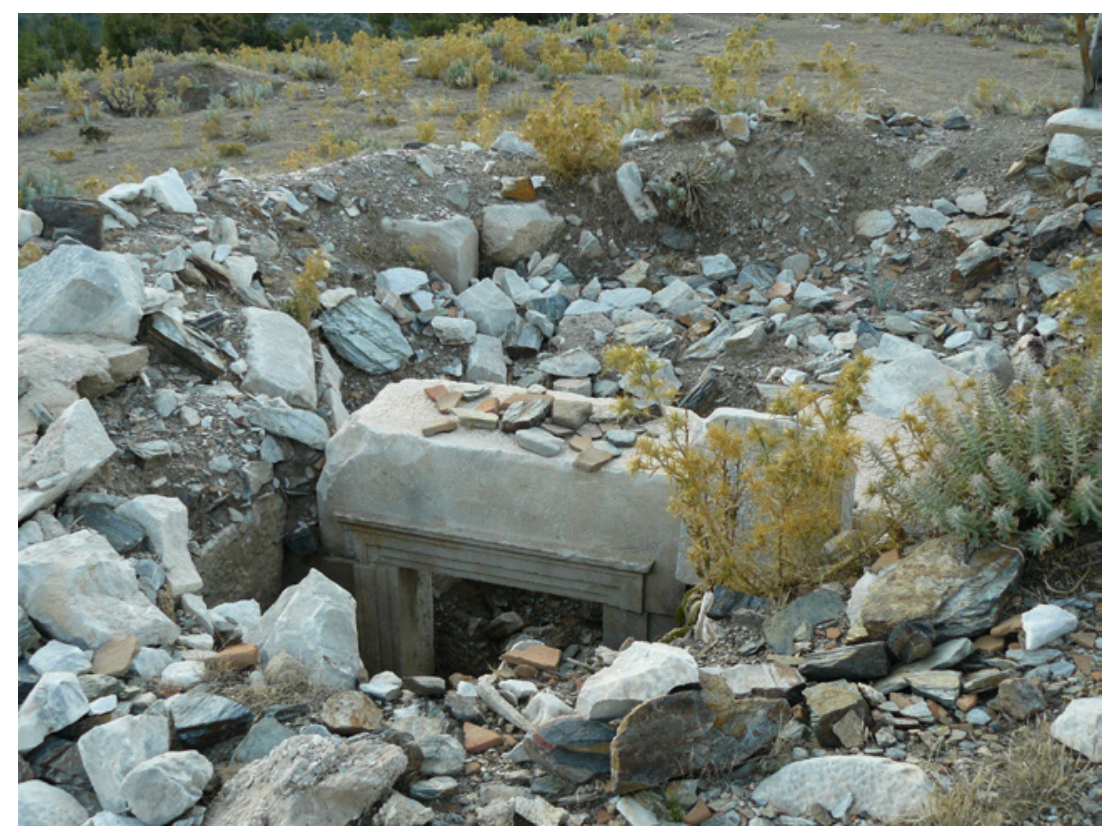

FIGURE 6.26 Panamara. Exposed marble doorway, with a three-faceted frame; the entry is c. $70 \mathrm{~cm}$ wide

PHOTO AUTHOR 2010

made of marble ashlars, with a finely carved three-faceted frame, probably belonging to a monumental chamber tomb (Figure 6.26). ${ }^{80}$ The sacred road was also a funerary road, and, as at Labraunda, this would have given those who joined in the processions a keen sense of time, both through the generations who had passed before as well as those to come.

The sacred road played a key role in the festivals of Zeus and Hera, as it carried the processions that included the entire population out towards the sanctuary for the festivals of the Heraia and the Komyria, discussed in the next section. Yet during the Panamareia, it also brought the cult image of Zeus into town, on horseback, in a majestic ceremony. ${ }^{81}$ Like Hekate's kleidos pompe, which brought the sacred key from Lagina to the bouleuterion, the dynamics of this ritual for Zeus were centripetal, drawing the most emblematic object of the sanctuary into the social, economic, and into the political heart of the city, in a solemn ceremony in which the entire community participated. At the

8o Lars Karlsson noticed similarities with the marble tomb near Labraunda, published in Henry (2011) (pers. comm. 15.09.2011). The doorway was exposed between my visits to the site in 2008 and 2010.

81 E.g. I.Stratonikeia 309, line 15, a later inscription from the third century AD. 
end of the festival, the image was returned to the sanctuary in the ritual of the anabasis, in which it was brought back to the temple. ${ }^{82}$ Anabasis can mean 'ascension' but it can also mean 'mounted', as on horseback, and in this context it is significant that after the mid-first century в С Zeus Panamaros appears as a rider-god on the coinage of Stratonikeia. ${ }^{83}$

The processions physically linking Stratonikeia to the cult of Zeus at Panamara would have been one of the ways in which the rituals of Zeus were transformed by the polis after it absorbed the cult. Until that time, the scope of the sanctuary was primarily oriented towards the southern regions of Karia, particularly around the Marsyas valley. These processions, and the road that carried them, gave a strong northern axis to the sanctuary, emphasizing its connection to the polis. The monumentalization of this road, paved or not, would have been shaped by the ritual habits of the Stratonikeians, as they left their marks on the passage to and from the sanctuary.

In short, the topography and natural defense of the hilltop defined in part the character of the cult of this supreme deity, and the use of the sanctuary throughout much of its history. The Panamareis built a monumental and fortress-like sanctuary that was impressive enough to attract the attention of Philip v, who installed a garrison for his troops at the end of the third century вс. Unlike Lagina, the sanctuary of Zeus Karios was already architecturally developed as a complex prior to the advent of Stratonikeia in the midsecond century BC. Judging from the inscriptions, modifications by the polis came much later, with the addition of a temple for Hera that was attacked by Labienus's troops in the mid-first century вс, and later facilities dedicated by priests, e.g. dining halls, stoas, sleeping accommodations. Although epigraphy is our main source for the impact of the polis on ritual space, and hence the rituals, there are many indications of concentric spaces defined by architecture. Linear space is indicated via the processions known to have taken place, although current mining activities will have obliterated the route. Yet whatever the actual route was, the passage to the sanctuary would have meshed the visual region of Panamara with that of Stratonikeia, creating a sense of closeness between the two while significantly expanding the reach of the polis to the south. Grand urban processions took place that carried the entire population from the city out to the sanctuary and were also centripetal, bringing the sacred cult image of Zeus back into the heart of town. Much like the kleidos

\footnotetext{
82 The return procession of the anabasis is testified in I.Stratonikeia 161, line 9; 295a and b, line 10 (identical texts); 309, line 10; 341, line 3; and in 352, line 7 .

83 Meadows (2002), Group 4 (see Figure 6.30); discussed in more detail below under Civic Iconography.
} 
agoge from Lagina, these processions and the road itself turned the focus of cult towards Stratonikeia, making the sanctuary of Zeus at Panamara a beacon of Stratonikeian presence in the wider region.

\subsection{Ritual Performance at Panamara}

As with the sanctuary of Hekate at Lagina, processions were a critical part of the festivals, ensuring that Stratonikeia was the focus of the community and the cult. Several changes took place in the festivals at Panamara as the city absorbed the cult, regarding their frequency, content, but also the ritual space as the cityscape became integrated into the festival venue. Festivals physically established the bond between community and sanctuary, but they also served to mark this bond in the calendar year and in the cyclical life of the polis. The festivals at Panamara will be seen to have functioned as rational rituals as they were particularly centered on social cohesion, especially through the effectiveness of spectacle and its imprint on collective memory.

\subsubsection{Festivals}

Nearly all of our information pertaining to the festivals at Panamara dates from the later Hellenistic and especially imperial periods. How the cult was organized under the koinon of the Panamareis is largely unknown, although Philip v is known to have dedicated phiales (libation bowls) and a kados (jar) at the sanctuary. ${ }^{84}$ The Panamareis surely bestowed their honors on such individuals during public festivals for Zeus Karios, but the only information that we have of this stems from the dossier of inscriptions pertaining to Leon, the priest from Stratonikeia who expanded the festivals by getting the communities to increase the splendor of their sacrifices, and by getting more communities to participate. ${ }^{85}$

The festivals would have revolved around the altar, but its location is less than clear, as discussed above, and Laumonier suggested it as the isolated pile of marble found at the western end of the sanctuary. Despite our limited knowledge of the configuration of ritual space, numerous testimonies of ritual performances at Panamara can be found in the epigraphic record. Several are listed in I.Stratonikeia 1 . This inscription highlights the intertwinement of music, the molpen, with the sacrifices at Hera's biennial festival, starting with oxen sacrifices and followed by a second part that mentions white cattle, a billy-goat, and a cock as the victims. Initially dated to the third century вс, the

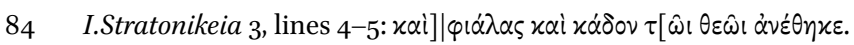

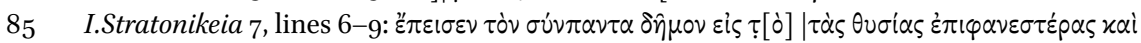

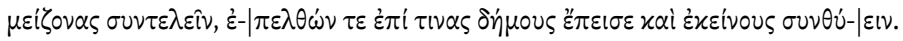


two sections now appear to belong to different inscriptions, and probably date from the later second or first century $\mathrm{BC}$, when the sanctuary and its festivals were organized by Stratonikeia. ${ }^{86}$ Both sections do, however, give us a glimpse into the nature of the sacrifices, with the kinds of animals, apparently all of which were mature. The emphasis on music accompanying the sacrifices is rare and would indicate an especially significant role in the festivities. Music would again be the focus of attention much later, in the second or third century AD, in the inscription of Sosandros, who prescribes the singing of hymns for Zeus and Hekate, according to tradition, all day long during the days of their festivals. ${ }^{87}$

Hera's temple was discussed in the previous section, and I.Stratonikeia 1 shows that her festival had become a regular feature of the cult at Panamara, occurring every other year. The inclusion of Hera in the cult of Zeus was attributed by Laumonier to its takeover by Stratonikeia, in the context of a wider reorganization of the cult. ${ }^{88}$ Although neither the introduction of the cult of Hera nor the absorption of the sanctuary by the city can be dated with any degree of accuracy, the two events seem related, as Laumonier presumed, although probably at a later date. It is difficult to understand the context of the introduction of Hera's cult without a clear chronology for this early phase and van Bremen challenges Laumonier's assumptions with reason. ${ }^{89}$ Yet the inclusion of Hera's cult and the addition of her festival to the calendar of the polis certainly helped coordinate the pre-existing communities within the larger area, shifting their focus to the now urban community. The priestly dedications to 'Zeus, Hera, and the demos' in any event sealed the link between both deities and the polis. ${ }^{90}$

86 I.Stratonikeia 1 is generally interpreted as a calendar, see also Sokolowski, LSAM No. 67, 159-16o. Hatzfeld (1927), 68 n. 1 and No. 9, 69-70, dated it to the mid third century BC, based on the lettering. This is however taken by van Bremen as more characteristic of the first century BC, see van Bremen (2004b), 225-226. The cult of Hera at Panamara is further discussed in Williamson (2020b), also Pirenne-Delforge and Pironti (2016), 186, n. 431 and 194, n. 468.

87 I.Stratonikeia 1101, discussed above in Chapter 5, under Festivals.

88 Laumonier took this inscription, with its date in the third century вС (Hatzfeld (1927), p. $68 \mathrm{n} .1$ and 69 no. 9), as a sign of Stratonikeian reorganization of the cult at Panamara in this early period already, Laumonier (1958), 234-235; followed by Debord (2007), 240. Van Bremen, however, assigns a later date to the inscription, making it even more plausible that the cult of Hera was introduced under Stratonikeian control of the shrine, van Bremen (2004b), 225-226.

89 Van Bremen (2004b), 226-227.

9o Dedications to Zeus, Hera, and the demos in the Hellenistic period appear in I.Stratonikeia 102, 103, and 332, these are discussed below under Administration and Priesthoods. 
The Heraia is the earliest festival mentioned in the inscriptions at Panamara. This took place in and around the sanctuary and was focused on women, but involved the entire population, whether citizen or foreigner, from the city or the countryside. ${ }^{91}$ Sources for the Heraia largely stem from the imperial period. One of the earlier documents from the first century AD, I.Stratonikeia 174, is highly interesting in many respects. The priests are seen to arrange and escort the population out to the sanctuary, presumably in procession, leading the women into the Heraion while the men waited outside, and later escorting them all back to town again..$^{92}$ The adult female population of Stratonikeia is designated as 'the corporate body of women' (to poleiteuma ton gynaikon). ${ }^{93}$ How formal this collective identifier was is uncertain, yet even if it did not reflect institutional power it did create a religious reality. Directly connected to this is a theoria, and so women appear to have been involved in the capacity of bringing expensive and beautiful things to Hera in Panamara. ${ }^{94}$ The term theoria literally means 'seeing the gods', and although it more often refers to delegates at festivals from other poleis, it is also used on occasion to designate a particular segment of local society, usually the ephebes. ${ }^{95}$ The festival was biennial, but a number of inscriptions in the imperial period also refer to a penteteris for Hera. The earliest involves a dedication to Zeus, Hera and the demos by a Leon and Myrtale, a brother and sister priestly couple who held office during the penteteria. ${ }^{96}$ Mysteries were also held for the women during

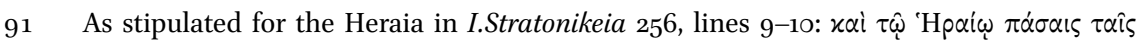

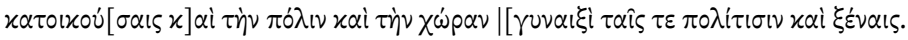



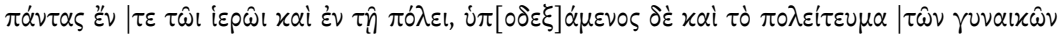

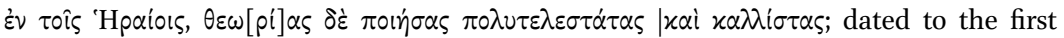
century AD; also I.Stratonikeia 256 . On the normalizing aspects of processions, projecting the ideal nature of the community, see Chankowski (2005).

93 I.Stratonikeia 149, 174, and 352, from the imperial period at Panamara, mention the

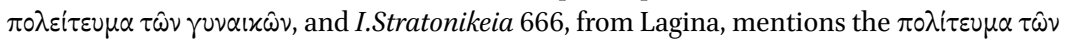

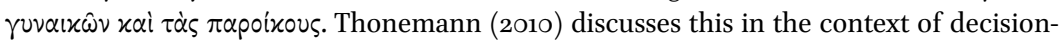
making responsibilities, while Cousin (1904a) observes that a collective group of women ( $\dot{\varepsilon} \rho \alpha v i \sigma \tau \alpha i)$ were among the contributors at Athens (IG II ${ }^{2} 2354$ [30]). Harland (2014), 338, addresses the corporate body of women at Panamara in the context of an association

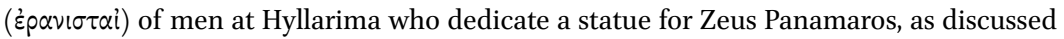
in Robert (1937), 513-515.

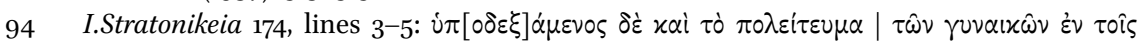

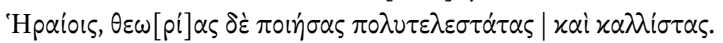

95 Theoroi are typically delegates to festivals of other cities, see e.g. Perlman (2000); Dimitrova (2008); and especially Rutherford (2007) and (2013) on aspects of reciprocity and network building. On ephebes as theoroi, see especially Kowalzig (2007a), 45, 59 .

96 I.Stratonikeia 108, from the late first century вС or early first century AD. They apparently dedicated a house with a place to lie down, with a stuccoed or stained entrance and 
the festivals of Hera, and priests took great pride in being able to assemble a large group of female citizens and foreigners, from the town and countryside, for these special ritual events. ${ }^{97}$ The dedications of hair that took place in the third century AD were primarily male, but also included some from women, such as Apphion, or general members of the household, including family and slaves. ${ }^{98}$

The Komyria, for Zeus, was restricted to men. The name refers to the Karian deity Komyros, who according to Lykophron was syncretized with Zeus at Halikarnassos. ${ }^{99}$ Whether this reference to the cult allows us to infer its presence at Panamara in the third or second century already, as Hornblower suggests, is debatable. ${ }^{100}$ Inscriptions mentioning the festival at Panamara do not appear until the imperial period. They indicate that the festival took place over two days and included rituals of drinking wine, mysteries, and dedicating locks of hair. This last practice occurred in the second and third century AD and must have been fairly common, given the number of dedications (99 have been published, see Table 6.1 below). ${ }^{101}$ Special containers were made to keep the locks of hair, a number of which may still be found at the sanctuary (Figures 6.27). Some of the letters written by the priest to foreign cities are invitations to participate in the festivals and the mysteries, indicating this as a wider attraction in this period. ${ }^{102}$ In the meantime the women waited

paintings. The bulk of the 23 inscriptions mentioning the penteteria are dated to the first or second century AD, see further Laumonier (1958), 239-240.



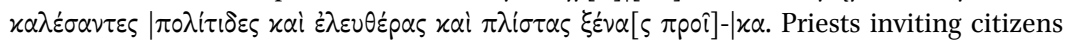
from every category for the Panamareia, and women from town and countryside for the Heraia are seen in I.Stratonikeia 256, esp. lines 9-10.

98 The dedication of Apphion's hair is commemorated in I.Stratonikeia 485, although it should be noted that it is her father, Sosandros son of Hekataios, who takes the initiative to dedicate his daughter's hair, along with statues of Perseus and the Gorgon, to Zeus Panamaros. Other household dedications are represented, as 'familia' in I.Stratonikeia 486-488, or slaves (oiketes or doulos) in I.Stratonikeia 489-491.

99 Lykophr. 459-46o.

100 Hornblower (2015), 85-87. Lykophron refers to the worship of Zeus as Komyros in Halikarnassos, which Hornblower takes to represent all of Karia, in reference to the pri-



101 I.Stratonikeia 42, 401-50o, 1414; Deschamps and Cousin (1888c), nos. 6o-120 and p. 480. This practice spilled over to Lagina, where two dedications of hair were also made, I.Stratonikeia 545 (to Demeter?) and 1422. Writing in the second century AD, Lucian (De Dea Syria 6o) mentions that the locks of chin hair he once dedicated to the Syrian goddess were still kept in the sanctuary in a vessel with his name on it; he refers to a similar practice in Troizen where youths (male and female) were required to sacrifice locks of hair to Hippolytos prior to marriage.

E.g. I.Stratonikeia 23, to an unknown city, and to Mylasa in I.Stratonikeia 3 o. 

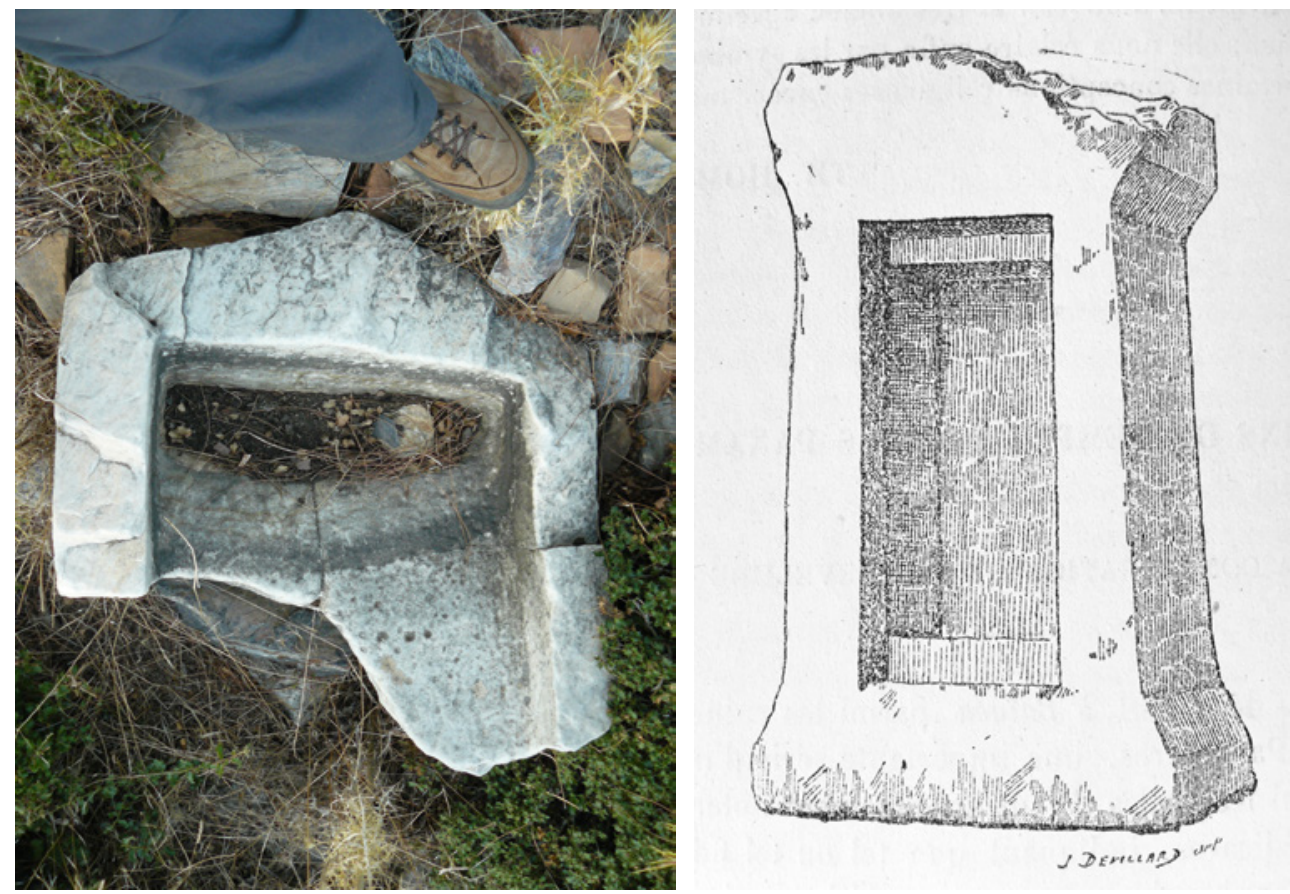

FIGURE 6.27 Panamara. Votive coffers, probably for hair dedications. On the left a marble coffer in the northern area near the temenos wall; illustration of such a coffer from Panamara by J. Devillard

Рното AUTHOR 2010; BCH 12 (1888), 480

outside, perhaps in the large level area at the northern part of the sanctuary (Figure 6.18), where they were tended to with wine and olive oil. In many ways, the Komyria was a mirror of the Heraia, as the festival was targeted gender while simultaneously accommodating the entire population. ${ }^{103}$

Although it is unknown when the major festivals began, it is tempting to associate them with the Senatus consultum after the Mithridatic Wars, when Stratonikeia was granted a wide expansion of territory to the south, down to the Gulf of Keramos. These festivals and their processions certainly enacted Stratonikeia's territorial claims, but rather than staking out boundaries, they were directed at the social structure of civic society. Resulting from a major reorganization of the sanctuary at Panamara by Stratonikeia, they helped

103 For an extensive description of both festivals, based mostly on inscriptions from the imperial period, see Hanslik-Andrée (1949), s.v. 'Panamaros' in the RE. Much of this may be read in I.Stratonikeia 202-203, and 205, and the dedication of hair during the Komyria in I.Stratonikeia 401-500. On the Heraia, see also Lozano 1991-92. Nearly all the priestly inscriptions from the imperial period show that the annual priesthood was held by a couple, with the male priest presiding over both festivals, see below under Administration and Priesthoods. 
produce the very intimate relationship between the polis and the broad base of its community that found expression at this remote shrine. The inclusion in the celebrations of all classes of men and women, slave, free, citizen or foreigner, would have fostered social cohesion, while situating each individual in his or her own specific social context. Inscriptions prove that Stratonikeia was always highly conscious of its deme divisions; the use of the demotic in this case allowed people from the ancient villages to retain their local identities while at the same time being full members of the polis. The processions to Panamara and the festivities there would have served as a focus which helped bring unification to the entire population. Panamara, remote as it was from the administrative center, may well have been an ideal 'neutral zone', where the participants could celebrate the most essential things which they had in common - their gender and their identity as Stratonikeians. The explicit inclusion of foreigners, the xenoi, may well refer to the visitors from the cities who were personally invited by the priest to join in the festivals. ${ }^{104}$ Their presence would no doubt have served to heighten local awareness even more, while extending the cult network in the region.

While these two festivals emphasized the social identity of the community, there was yet another festival of Zeus that was overtly political. The Panamareia marked a turning point in the life of the cult after the epiphany of Zeus of Panamaros that saved Stratonikeia from Labienus's invasions in 4 о вс. ${ }^{105}$ Sources for this festival date from some time after the miracle, yet even an inscription from the later imperial period connects the festival to the miraculous power of Zeus and testifies to a continued awareness of the epiphany. ${ }^{106}$ The festival of the Panamareia was an annual event of great significance for the polis. Oppermann views the term 'succession of the crown', appearing in several inscriptions, as a sign that this was politically the most

104 I.Stratonikeia 22-39 are letters written by the priest of Panamara to various periods; discussed below in more detail. An interesting parallel may be found in Mylasa, where the gymnasiarch Leontiades is honored by the paroikoi, metoikoi, and xenoi who otherwise had no share in the oil distributions in the gymnasium Blümel (2004), 16-17, no. 22; also Blümel et al. (2014), no. 18.

105 The miracle is described in I.Stratonikeia 10, discussed below under Urban Mediatization.

106 I.Stratonikeia 266 (dated to the later second or third century AD), lines 10-22, with

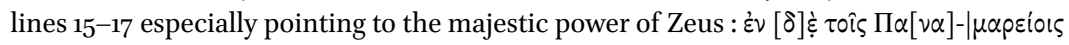

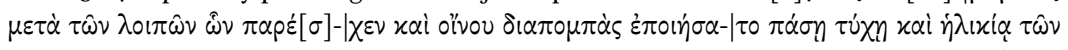



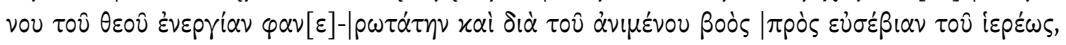

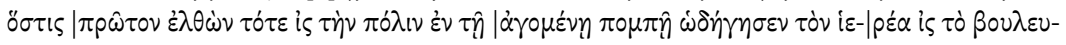

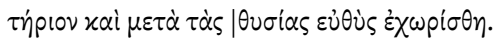


important festival for the city of Stratonikeia. ${ }^{107}$ It was certainly the longest, lasting ten days, ${ }^{108}$ and involved intensive banqueting with gifts of oil, wine, and money for the population. ${ }^{109}$ Priests usually distributed these gifts and some inscriptions explicitly include citizen, foreigner, free, and slave as recipients of their liberal generosity. ${ }^{110}$ Much went on in the countryside too and one inscription even includes the sanctuary of Hekate at Lagina as a scene of festivity during the Panamareia, intertwining the two main deities during this centralizing festival. ${ }^{111}$ Together, both cults were engaged in directing the gaze of the communities towards the polis through cult and spectacle. The awe and wonder would have engrained the festivals into the social memory, thereby ensuring their endurance. ${ }^{112}$

One of the most interesting facets of this festival within the context of this study is that, just like Hekate's festival, it was primarily celebrated in town, not out at the sanctuary. As mentioned above, the image of Zeus was brought from Panamara into town in a procession, possibly on horseback, to reside in the bouleuterion during the festival; afterwards it was returned to the sanctuary during the festival of the anabasis. ${ }^{113}$ For Stratonikeia it was then critical to have some token or representation of the gods physically residing in the urban

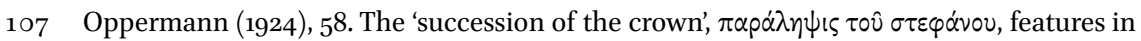
I.Stratonikeia 247, 281, 312, 341, among many others.

108 The length of the Panamareia at ten days (and nights) is attested e.g. in I.Stratonikeia 247,

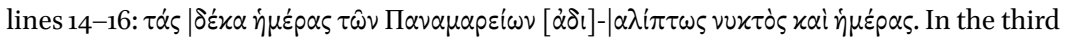

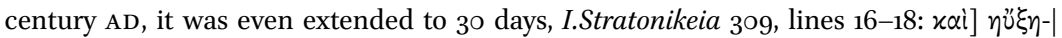

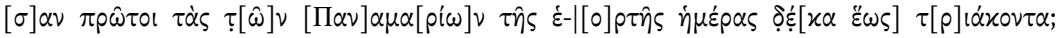
added up with Hekate's kleidos agoge, both festivals took 34 days in this later period:

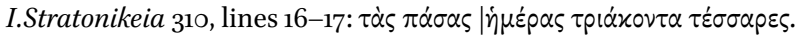

109 For example the distribution of oil during the rite of the 'succession of the crown', in

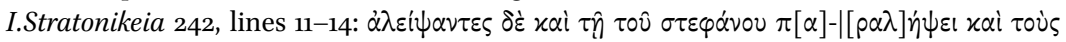



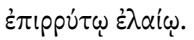

110 The distribution of oil during the rite of the 'succession of the crown' is mentioned in

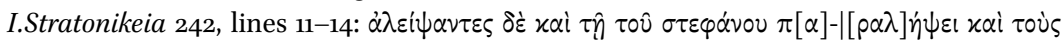



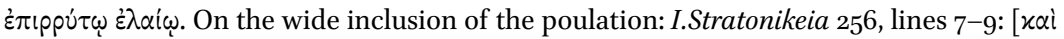

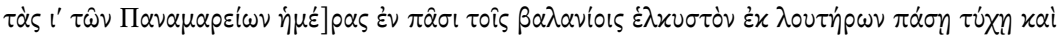

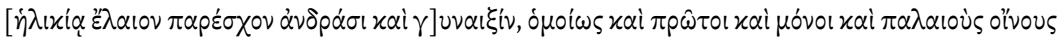

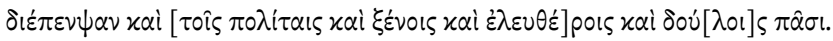

111 I.Stratonikeia 266, lines 11-15, cited above in note 106.

112 See Connerton (1989), 41-71, McCauley and Lawson (2002), 38-88; discussed in Chapter 2.

113 I.Stratonikeia 266, mentions the procession into town lines 18-22, see note 106;

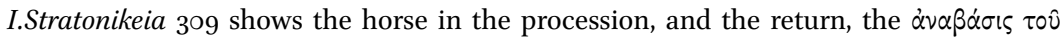

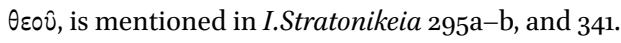


center for a period of time, perhaps because they were otherwise visually isolated from the sanctuary, this aspect is further discussed below.

None of the inscriptions referring to the festival of the Panamareia can securely be dated to the pre-Roman phase of Stratonikeia; the majority in fact seem to have been written in a solid imperial context. Oppermann believes the Panamareia to have begun at least after the Mithridatic wars, yet a more fitting context would be the epiphany of the god that saved the polis from Labienus and his Parthian troops in 40 BC. ${ }^{114}$ By this time Panamara was thoroughly integrated with Stratonikeia, and Zeus Panamaros had come to represent, and to protect, the polis.

\subsubsection{Banqueting}

As with the festivals of Hekate, feasting was clearly a major part of the festivals of Zeus Panamaros. This was indicated already in I.Stratonikeia 1, discussed above, where a number of animals are mentioned in connection with the sacrifices and the feasts. This provides us with a glimpse of the role of banqueting in the festivals. A later inscription for an unnamed priest shows how he welcomed and generously fed the entire community at the sanctuary, apparently for two days. ${ }^{115}$ The letters written by the priest to a number of cities invite them to join in the sacrificial banquet. ${ }^{116}$

These are just a few of the many examples that show the central role of feasting as a ritual performance in the festivals at Panamara. Although we can say little about the spatial form which this took at the sanctuary in the Hellenistic period, some structures known through inscriptions from the early imperial period - the stoas and perhaps the vaulted structure ( $p$ salis) and porch (pastas), both built by the priest Posittos, son of Apellos - -117 may at least have provided shelter or even a formal reception area, while the philotrophion and the aristeterion were surely designed for banqueting, built later in

114 Oppermann (1924), 83: 'dies Fest ist also nicht viel älter als Sulla'. Oppermann dates the annexation of Panamara by Stratonikeia to the territorial expansion granted in the senatus consultum after the Mithridatic Wars and postulates the Panamareia as following this event.

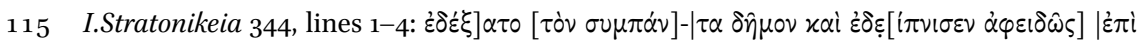

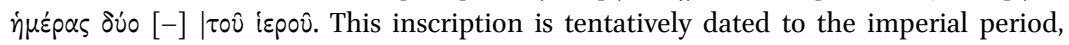
although the phrase $\dot{\varepsilon} \pi \dot{\eta} \dot{\eta} \mu \varepsilon_{p a \varsigma} \delta \dot{0} 0$ is also used in I.Stratonikeia 1409, dated to the Hellenistic period.

116 E.g. I.Stratonikeia 22, the letter to the Rhodians. See also I.Stratonikeia 23 (unknown city); 25 (to Alinda); 29 (unknown city); 33 (unknown city); and 35 (unknown city).

117 I.Stratonikeia 112, discussed above under Architecture. 
the second or third centuries AD. ${ }^{118}$ Besides this, however, the many tents and other provisional structures were surely part of this massive event, as well as general feasting al fresco.

According to the epigraphic record, banqueting in festive Stratonikeia was on the rise in the imperial period. As with the festivals of Hekate this became one of the central communal activities of the Panamareia. ${ }^{119}$ When the procession brought the cult image down from the hilltop sanctuary and into town, the festival descended on the urban landscape. Ritual feasting occurred mostly in the magnificent gymnasium, ${ }^{120}$ but also in places such as the temple for Dionysos. ${ }^{121}$ The countryside was included, too. One inscription even mentions the sanctuary of Hekate at Lagina as a scene of action during the Panamareia, showing the intensive collaboration of both poliad deities during this major festival. ${ }^{22}$

The festivals of Zeus Panamaros and Hera were highly social events, cutting through the regular social boundaries, e.g. male-female, citizen-foreigner, freedman-slave, urbanite-countryman, young-old, and ritual feasting was especially suited for this purpose; ${ }^{123}$ one inscription even explicitly includes Romans among other marginal groups. ${ }^{124}$ Schmitt-Pantel has shown that sacri-

118 The philotrophion was built by the priest Drakon, son of Leon of Koranza, I.Stratonikeia 267 , dated to the later second or third century AD; in the same period the aristeterion is mentioned in I.Stratonikeia 17 , an honorific decree dated to the second or third century AD for an unnamed priest who made improvements, perhaps expansions, to the aristeterion, and who also provided for a sleeping chamber (koiton) in the vaulted room (psalis).

119 E.g. I.Stratonikeia 192, including gifts of olive oil; also discussed in Stavrianopoulou (2009), 178 n. 61.

120 The gymnasium was also a general scene for receptions, e.g. for women in I.Stratonikeia

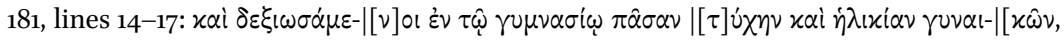

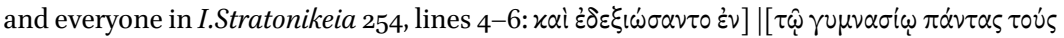

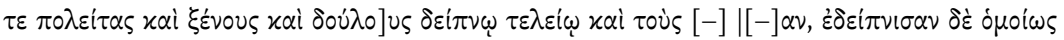


$\dot{\eta} \mu \varepsilon \varepsilon_{\alpha} \alpha \varepsilon \varepsilon \tau v \varepsilon[i]-\mid[\sigma] \alpha \nu \tau o \varsigma$, an honorific decree for the priest Titus Flavius Aeneas (by his brother Titus Flavius Aristolaos). Inscriptions concerning the gymnasium: I.Stratonikeia

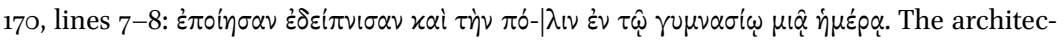
tural development of the gymnasium is described in Mert (2008), 16-20, and 156-166.

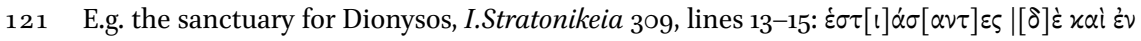

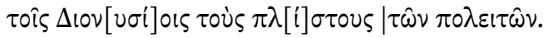

122 I.Stratonikeia 266 , lines 11-15, see above, in note 106.

123 E.g. I.Stratonikeia 172, 203, 205, 210, 242, 252, 255, 256, 318, most of which are dated to the second century AD.

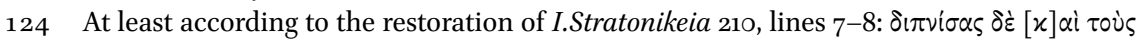

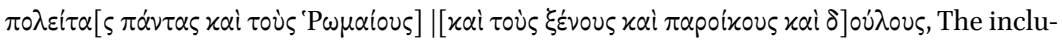
sion is by analogy with I.Stratonikeia 186 and $1325 \mathrm{~A}$, where Romans and other foreigners are mentioned as living in the countryside; Gordon (1990), 226-228. 
fices and the ensuing banquets were a collective and political action that was at the heart of Greek urban experience. ${ }^{125}$ This was certainly true at the festivals of Zeus Panamaros. But especially in the later imperial period we also see that certain banquets were hosted by the priests for specific groups, such as the gerousia, who were exclusively entertained by the priest Theophilos in a banquet held in town. ${ }^{126}$ The festival banquets of Zeus and Hera, but also Hekate, drew the community together, providing a shared focus and a common bond, but at the same time they could also be used to create or confirm social distinctions and establish urban conventions. ${ }^{127}$ As part of a ritual and social meal, banquets such as these were excellent rational rituals - they created both joint attention, and common knowledge, i.e. everyone knew about the banquets and could expect to participate, knowing that others were doing the same at other venues. ${ }^{128}$ Moreover, banqueting throughout the urbanized landscape served as a way of 'shaping territory'.129 Like the processions, it created an indelible link between the chora, the ritual which included the fellow banqueters, the god, and the polis. Not only did it create and maintain social cohesion, but it was also critical in establishing or maintaining the territorial identity of the polis.

\subsubsection{Games}

Although competitive games or athletic contests are not as prominent at Panamara as they are at Lagina, they may nonetheless have been part of the festivals, at least in the later imperial period. Two related inscriptions include games that occurred at the occasion of the anabasis, or the return of the image of Zeus to Panamara. ${ }^{130}$ Theatrical and athletic competitions are mentioned in

\footnotetext{
125 Schmitt Pantel (1985) on the importance of banqueting an sich as a social activity; also Schmitt Pantel (1990). One of the main lines of her thesis is that the division of the victim into equal parts represents the political equality, or isonomia, of a community.

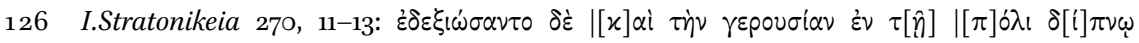
$\dot{\alpha} \pi \circ \varphi \circ \rho \eta \dot{\tau} \omega$.

127 Scheid discusses this aspect in sacrifices in the imperial period, but with respect to the division of the victim in unequal parts, corresponding to social distinction, Scheid (1985). See also the banqueting at Labraunda which was both a communal and segregated event, through the architectural facilities, discussed above in Chapter 3; and at the sanctuary of Sinuri which was the prime communal event in which individuals were distinguished through the sacrificial meal and the division of the meat, see Chapter 4.

128 Chwe (2001) on 'rational rituals', as an effective means of creating common knowledge, discussed in Chapter 2.

129 See 'territorial shaping' as the first stage in Paasi's model of building regional identity, Paasi (2009); discussed above in Chapter 2.

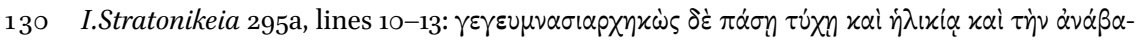

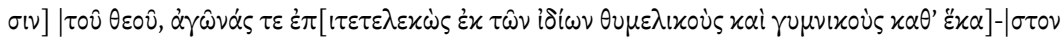


a priestly dedication. ${ }^{131}$ These competitions appear to have taken place toward the end of the Panamareia, perhaps as a kind of closing ceremony in which the city's finest were on display in a memorable performance. Otherwise, much less is known about the games at Panamara, or during the Panamareia, than those at Lagina. Assuming they were costly to organize, then one might imagine Stratonikeian focus on games to be during the Hekatesia, while the festivals at Panamara were more concentrated on social rituals such as mysteries and opulent feasting.

To summarize, the festivals at Panamara clearly helped unite a dispersed population. Regardless of origin or class, from the city or the countryside, citizen and stranger, they were all called upon by the priests to join and were brought out to the sanctuary together to celebrate the festivals of Zeus and Hera. The focus on social gender through the Komyria for men and the Heraia for women cut across all other distinctions, although the presiding priests were clearly members of the urban elite who organized and escorted the community in the processions; their role is discussed in the next section. The processions of the Panamareia, the great festival established after Zeus's miraculous salvation of the Stratonikeians, mirrored the kleidos agoge from Lagina in that they were also centripetal, bringing the image of Zeus on horseback down from the hilltop and into town, probably to the bouleuterion. The emphasis on music in the ritual of the sacrifice is exceptional, or at least exceptionally preserved..$^{132}$ Whatever type of song the molpen was, mentioned in I.Stratonikeia 1, it appears to have been simple and repetitious, supporting the mnemonic mechanisms of ritual and would probably have been memorized by heart. ${ }^{133}$ This surely had a significant role as a rational ritual in creating the shared focus that helped forge the community belonging to the sanctuary. ${ }^{134}$ The sense of community would have been heightened by the communal feasts. The banquets connected to this feast took over much of the urban and rural landscape,

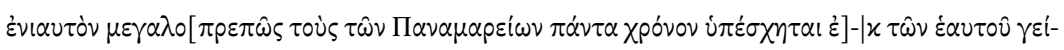
$\nu \varepsilon \sigma \theta \alpha[\iota$ $\alpha \dot{\tau} \tau \cup$ $\varsigma$, as restored by the editor. I.Stratonikeia $295 \mathrm{~b}$ is very similar, but even more fragmented.

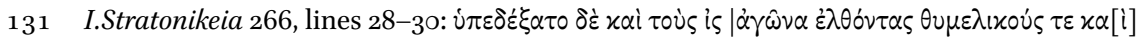
$\mid \xi \cup \sigma \tau \varkappa \propto \nu \dot{\varsigma} \alpha \dot{\theta} \lambda \eta \tau \alpha \dot{\alpha}$.

132 I.Stratonikeia 1 and 1101, respectively. The notation of music at the sanctuary of Sinuri, discussed above, is an interesting exception to the otherwise general dearth that has survived; see however the Delphic hymns, e.g. in Furley (1995).

133 McCauley and Lawson (2002), 38-88, on memory and religion. The element of repetition was surely involved in the hymns that were composed and sung all day long by the choirs of youths at the festivals of Zeus and Hekate in the later imperial period, I.Stratonikeia 1101.

134 Also Kowalzig (2007b). 
even including Hekate's sanctuary at Lagina, demonstrating how intertwined both cults had become by this time. Connecting the symbols of these distant gods to the political heart of the city reinforced the religious axis of the sacred landscape, embracing as it were the young polis. ${ }^{135}$ The games added to the sensory value of the spectacle; using the gymnasium as banquet venue would moreover have been a way of integrating the youth into the fabric of the urban festivals, ensuring continuity into the following generations and reinforcing civic institutions. The later dedications to the demos, alongside Zeus and Hera, show that Stratonikeia had positioned itself at the ritual center of Panamara by the second and first centuries BC. Ritual spectacle and repetition helped foreground the sanctuary in collective memory, thereby shaping the territory through the interlocking pattern of landscape, deity, and polis.

\subsection{Legal Administration and Organization of Panamara}

The degree in which a sanctuary was autonomous or integrated into the institutions of the polis is reflected in particular by the role of the priest and the status of the community at the sanctuary. The history of the administration of the sanctuary of Zeus Karios at Panamara revolves around the koinon of the Panamareis and the polis of Stratonikeia, and the relationship between the two. There is no evidence for a single moment in which the sanctuary passed hands from the koinon to the polis, although the priesthood of Leon seems to mark a shift in the otherwise long transitional period that starts with the control of the sanctuary by Philip v, when the Panamareis appear to have used the stephanephoros of Stratonikeia to date its decrees, ${ }^{136}$ until the later second century $\mathrm{BC}$ when the koinon of the Panamareis disappeared altogether and Stratonikeian control of the sanctuary was firmly established.

\subsubsection{Administration and Priesthoods}

Prior to the incorporation of Panamara into the urban realm of Stratonikeia, the sanctuary of Zeus was administered by the koinon of the Panamareis.

\footnotetext{
135 An interesting analogy may be found in Japan, the Kameshima village in Honshu, which uses "a linear, time-oriented axis from the mountain shrine projecting through the village shrine and to the field shrine," this ritual axis helps link the five fishing villages that make up the community, Thompson (1999).

136 I.Stratonikeia 4 , discussed in van Bremen (2004b), 230-231, who points out that this could be a result of both Panamara and Stratonikeia being controlled by Philip v. During the Rhodian period, until 167/6 BC, she assumes that like Panamara, Stratonikeia would also have followed Rhodian dating conventions. However, other than the installment of the cult of Helios and Rhodes at Lagina, I.Stratonikeia 504, no Stratonikeian inscriptions from this early period are known that would support this hypothesis.
} 
Although we know little of their internal structure, they were apparently able to organize the resources necessary for building a monumental complex with a temple. ${ }^{137}$ The cult may have been administered by a single priest, chosen from the koinon, as Riet van Bremen suggests. She tentatively dates one of the earlier priestly inscriptions to the first half of the second century, that of Androsthenes, son of Zoilos, who makes a simple dedication to Zeus Karios. ${ }^{138}$ This inscription does not inform us whether Androsthenes was appointed by the Panamareis or by Stratonikeia. But we do know that Stratonikeia appointed the Leon, son of Chrysaor, son of Zoilos, son of Polyperchon, of Stratonikeia, as priest of Zeus Karios while the cult was still under the administration of the Panamareis. ${ }^{139}$ It is tempting, as van Bremen observes, to see some kind of family relationship between Androsthenes and Leon (uncle and nephew?) since the name Zoilos (unlike Leon) is uncommon in the inscriptions of Stratonikeia. ${ }^{140}$

Leon's priesthood at Panamara is interesting for a number of reasons, many of which have already been discussed above. ${ }^{141}$ The fact that he is honored at the end of his term indicates that the position was probably annual rather than life-long, even while under the administration of the Panamareis. ${ }^{142}$ Also, the fact that Stratonikeia had the authority, or at least capacity, to appoint a priest at Panamara raises the questions of who ultimately had control over the sanctuary at this time, and the degree of dependency of the Panamareis koinon on Stratonikeia. In any event, the decrees of the Laodikeis and Kallipolis both show Leon to be a good arbiter, as he settled a dispute about an oath that was to be taken. ${ }^{143}$ The Kallipolitai honor Leon but also send a copy of their decree to the Stratonikeians, praising 'them for having appointed an excellent man

137 As evidenced by the architecture described in I.Stratonikeia 3 and 4 . The priesthoods of Zeus at Panamara and Hekate at Lagina are discussed in more detail in Williamson (2013b); see also Ackermann (2013).



139 Van Bremen (2004b), 210 observes that Leon's long name, tracing him unusually back three generations to Polyperchon, may indicate that he was a descendant from one of the Macedonian colonists. Leon's priesthood is further discussed in LaBuff (2016), 131-139 and Thomas (2019), 158-159. In his commentary of the Kallipolis decree, I.Stratonikeia 1401, Shahin follows the suggestion in Oppermann (1924) that Leon was from Alabanda, and became a Stratonikeian only after his inclusion in the koinon of the Panamareis, I.Stratonikeia III, p. 11.

140 Van Bremen (2004b), 226-227, n. 73.

141 See the Historical Overview at the beginning of this chapter.

142 Leon is honored by the Panamareis in I.Stratonikeia 7 , the polis of Kallipolis in I.Stratonikeia 1401 (= EA 25 (1995), 83-85, no. 1), and the Laodikeis in I.Stratonikeia 1402 (= EA 25 (1995), 85-86, no. 2).

143 I.Stratonikeia 1401, lines 12-13, and I.Stratonikeia 1402, lines 7-8. 
as priest in the most prominent sanctuary'144 Leon's actions at the sanctuary show that he had a wide range of latitude for undertaking the expansion of the cult and reinvigorating its network, which he did by first examining the archives of the sanctuary, then:

having reconstructed that the above-mentioned honours and (grants of) asylia adhered to Zeus and to the Panamareis, he persuaded the entire people to make the sacrifices more splendid and better and going to certain demoi he persuaded them, too, to participate in sacrificing; (in all this) he zealously promoted the cause of the god and of the koinon of the Panamareis not sparing danger or cost or suffering. ${ }^{145}$

Leon was given credit for 'reinventing' the traditions of this seemingly ageold cult and especially for intensifying the contacts with local communities that were once common to it. ${ }^{146}$ Clearly a principal actor at Panamara, he used the past to change the future of the cult, by invoking an ancient grant of asylia to revive and expand the festival network of the shrine. The same dynamics were later used by the polis at Lagina and again through another priest at Panamara, probably in the first century вс. ${ }^{147}$ Stratonikeia may also have been one of the cities to acknowledge the ancient asylia of Panamara, implying some kind of formal relationship. ${ }^{148}$ The Panamareis clearly had some degree of autonomy, and van Bremen dates this inscription to the period of transition in the mid-second century $\mathrm{BC}$, before the sanctuary was entirely controlled by Stratonikeia. ${ }^{149}$ Leon's personal motives for being so deeply invested at Panamara remain unknown. This may have been a means of self-

144 Leon's appointment by Stratonikeia is especially evident in I.Stratonikeia 1401 (EA 25

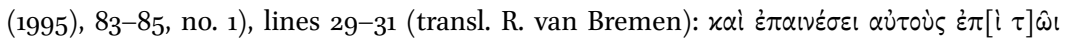

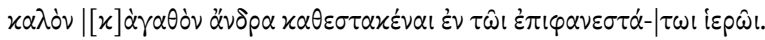

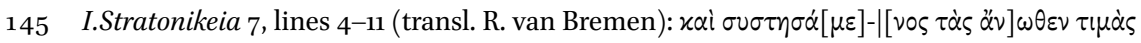



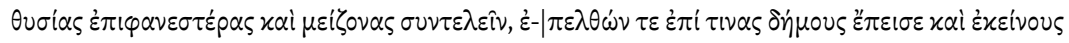

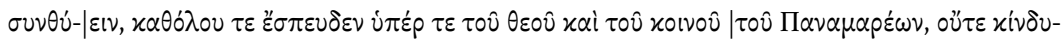

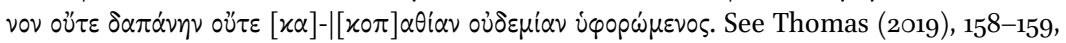
discusses Leon as a historian of the sanctuary.

146 The 'invention of tradition' is the topic of Hobsbawm and Ranger (1992), applied to the surge of festival culture in the Graeco-Roman era in van Nijf and Williamson (2015).

147 On asylia as an indicator for wider social interaction, see Ma (2003), also discussed in Chapter 2, Chapter 5 and below, under Scope and Network.

148 I.Stratonikeia 19.

149 Stratonikeia is apparently liberated from Rhodes, placing this after $167 / 6 \mathrm{BC}$; see further the discussion on the dating in van Bremen (2004b), 208-210 and in the Historical overview section at the beginning of this chapter. 
promotion by an ambitious member of the urban elite, as LaBuff suggests. 150 Equally, Leon may also have been acting on behalf of Stratonikeia in securing a strategic buffer zone of stability and goodwill for the polis down to the coast, as van Bremen argues. ${ }^{151}$ Whatever the original intent, Stratonikeia eventually did gain a foothold to the south, surely accelerated through the presence of the polis at Panamara.

Other remarkable aspects regarding the involvement of Stratonikeia at Panamara are known principally from the hiereus inscriptions, the priestly documents including their dedications and epangelias at the end of their office, summarizing their actions. The appearance of Hera and dedications to both the goddess and the demos of the polis are found among the priestly inscriptions. Menippos, son of Leon of Koranza, made as priest a dedication to Zeus Karios and Hera. ${ }^{152}$ Another inscription, by the priest Hekaton, son of Leon of Koraia, is dedicated to 'Zeus and Hera and the demos'.153 This trend was later followed by two priests, one of which was from Hiera Kome, who made a dedication to 'Zeus and Hera and the demos'. ${ }^{154}$ This would indicate that Stratonikeia shared the focus of cult by this time at least. Whether sudden or gradual, a major change did take place at some point in both the organization and content of the cult at Panamara. The biennial festival of Hera was in any event used as the chronological framework for the priesthoods of Zeus Panamaros into the imperial period - nearly a third of the priestly inscriptions refer to the Heraia.

Later priesthoods show a full integration with Stratonikeia, for example in the later first century BC, the priest Chairemon, son of Hekataios, son of Chairemenos of Koraia, presents an offering of thanks to Zeus Panamaros 'by

\footnotetext{
$150 \operatorname{LaBuff}(2016), 131-139$.

151 Van Bremen (2004b), 216-218, 237.

$15^{2}$ I.Stratonikeia 104; van Bremen (2004b), 226, who dates this "somewhat later" than that of Androsthenes, son of Zoilos, mentioned above; see also Laumonier (1958), 240-241.

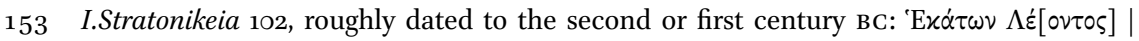

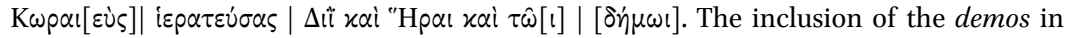
Hekaton's dedication is restored by analogy with I.Stratonikeia 103 .

154 I.Stratonikeia 103 shows Menander, son of Apollodotos dedicating a statue of Hermes to Zeus, Hera and the demos; I.Stratonikeia 332 is a simpler dedication by the priest [...] antos, son of Hydasou from Hiera Kome. This may be later than I.Stratonikeia 102 since the demotic is shown in abbreviation (IE), a practice that began towards the end of the second century вС. Later inscriptions, however, also use the demotic written in full, e.g. the priest Chairemon, son of Hekataios of Koraia writes his demotic in full, I.Stratonikeia 105 and 106, dated to the second half of the first century вС (Chairemon is also mentioned as priest in the miracle, I.Stratonikeia 10, Sherk (1992), 236 no. 145).
} 
vote of the demos, ${ }^{\prime 15}$ demonstrating that the priest is acting as an operative of Stratonikeia towards the god. Chairemon was the priest during the miracle at Panamara and this thank offering, with confirmation by the people of Stratonikeia, may well be an outcome of this momentous event. ${ }^{156}$ The priesthood was clearly a civic function by this later period, tightly interwoven with the administrative body of the polis. That priests had a euergetic role in the Hellenistic period already is demonstrated by a fragment with the priest distributing olive oil and wine to the population during one of the festivals. ${ }^{157}$ This would become a much more prominent feature of the priesthood in the imperial period, as shown by their building dedications. ${ }^{158}$ In the later Roman period, the priest was generally joined by a priestess, as at Lagina, typically his wife or a female relative; a major difference in the roles is that at Panamara the priestess had the official task of accompanying the women during the festivals. 159

The priesthood of Zeus at Panamara, like that of Hekate, became one of the most important and highly esteemed offices in Stratonikeia. Table 6.1 shows the high proportion of inscriptions associated with the priesthood; that it was filled annually, and recorded as the priest left office, is one of the reasons for the large number of these inscriptions found at the sanctuary of Zeus at Panamara, in use as it was over several centuries. ${ }^{160}$ The priesthood was probably an elected position, although the role of benefaction in the festivals became more and more important, as at Lagina, and so the circle of eligible

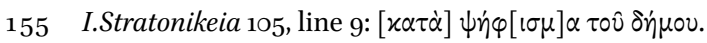

156 I.Stratonikeia 10, line 2 shows Chairemon as priest; see also Sherk (1992), 236 no. 145. Chairemon later became priest at Lagina and appears roughly midway in the list of priests, I.Stratonikeia 6og, lines 13-14 (dated to 38/37-28/27 BC).

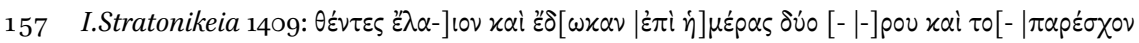
oivo $] \nu \pi \lambda \varepsilon[\hat{\imath} \sigma \tau$ \%

158 E.g. the dedications by Posittos, discussed above (see notes 63 and 64); Meier (2012), 145-151. Arjan Zuiderhoek has drawn attention to how common this phenomenon was in the imperial period, especially in connection with the general culture of the gymnasium, Zuiderhoek (2009), 89-92. See also above, under Festivals; the priesthoods of Hekate were also clearly euergetic, see Chapter 5 , esp. in note 259 .

159 The priesthoods of Panamara, particularly in the imperial period, are discussed in detail in Laumonier (1937), Laumonier (1938a), and (1958), 227-293. For the priestess at Panamara, see esp. Laumonier (1958), 227-228. Also Williamson (2013b) and especially Ackermann (2013) on gender roles.

16o This table only shows the published inscriptions, which derive mostly from chance surface finds and spolia from Bağyaka. Panamara has not been excavated and so proportions here will not be as reflective as they are at the sanctuaries in the other case studies. Even so, with over 400 inscriptions, Panamara has the largest collection by far, over half of which consists of priestly inscriptions. 
TABLE 6.1 Breakdown of inscriptions at Panamara according to type and period ${ }^{\mathrm{a}}$

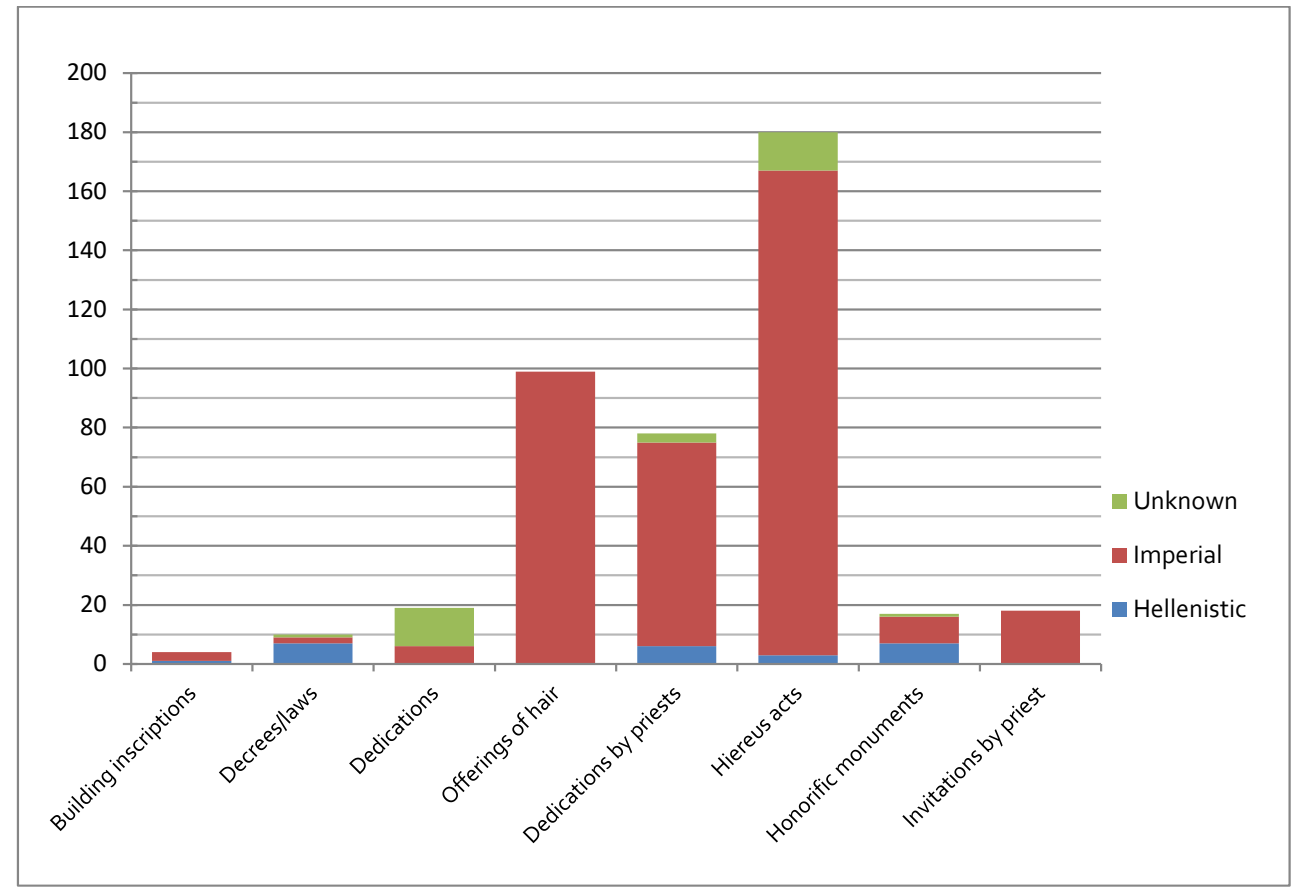

a Not included in this table are: the Senatus consultum de Panamara from 39 BC (I.Stratonikeia 11-12), a list of (responding?) cities (I.Stratonikeia 21), and a list of names from Hiera Kome and Koraia, of unknown date (I.Stratonikeia 45). The hair offerings are mostly from the later second or third centuries AD.

candidates dwindled to the most wealthy. ${ }^{161}$ This may explain why certain persons, such as Marcus Sempronius Clemens, could hold the office on five separate occasions, even combining it with the priesthood of Hekate in one year. ${ }^{162}$ He is not the only person to have held both offices, however; the fact that both priesthoods were on several occasions fulfilled by the same urban leaders, and

161 This may also explain why on occasion young boys or very old men were elected as priests, see Laumonier (1958), 227-228. The problem of recruitment is further discussed above with regard to Lagina, see Chapter 5 under Administration and priesthood.

162 I.Stratonikeia 289 (second half of the second century AD) gives the epangelia of Marcus Sempronius Claudius at Panamara in the Heraia, while being priest of Hekate; cf. I.Stratonikeia 16. His priesthood is extensively discussed in Cousin and Deschamps (1888); Nilsson (1927), 40o; Laumonier (1958), 277-280, 367; Frija (2012), 206-207, on his role as high priest of the imperial cult. 
thus major actors in the creation of cult identity, may also explain why the cults of the two main gods of Stratonikeia began to resemble each other more and more closely. ${ }^{163}$

Leon, mentioned above, provides an example of the initiative and latitude taken by a priest at Panamara in the Hellenistic period. Fragments from an intriguing set of documents, probably from the late first century BC, ${ }^{164}$ show that there was another priest, whose name is unfortunately lost, who also wrote letters to several cities inviting them to participate in the cult (Figure 6.28, discussed below). ${ }^{165}$ These letters are highly unusual, not only because they were recorded here at Panamara, but also because they were personally sent by the priest; neither Stratonikeia nor the koinon of the Panamareis are mentioned. Rather than being formulaic, the invitations were tailored to the situation, implying a personal history with each invited polis. ${ }^{166}$ Also, the invitations were explicitly extended to the entire population, not just envoys, theoroi, or other forms of representation. It would seem that this well-connected and well-informed priest took it upon himself to actively expand the cult network of the sanctuary, and had the knowledge and the means to do so.

This would in a sense seem to underscore the view of the priesthood as a semi-autonomous source of authority in itself, a legacy of the ancient theocratic system in Asia Minor, as Beate Dignas maintains. ${ }^{167}$ Of course the priesthood was fulfilled by members of the urban elite, and Stratonikeia seems to

163 Some individuals also held the priesthood of other cults at Stratonikeia, e.g. in I.Stratonikeia 249 Herakleitos, son of Apollonidos (etc) and his wife Tatarion, daughter of Myonidos had also held the priesthoods of Hekate as well as Zeus Chrysaoreus, besides the priesthood of Zeus Panamaros.

164 Hatzfeld (1927), 71-73; Curty (1995), 173-175, placing it after the epiphany of Zeus during the attacks by Labienus and the following grant of asylia in the Senatus consultum de Panamara of 39 ВС (I.Stratonikeia 11-12).

165 I.Stratonikeia 22 through 39b, discussed in Hatzfeld (1927), 71-73, and Curty (1995), 167175. No particular festival is mentioned in these letters, only mysteries and banqueting. The implications for the cult network of Panamara are discussed below, under Scope and Network.

166 Reminiscent of the great embassies of Magnesia on the Maeander in the second century BC, see Rigsby (1996), 179-279, also Williamson (in press-b) with references.

167 Beate Dignas tends to view the priesthoods of sanctuaries in Asia Minor across the board as a continuation of theocratic power in the Hellenistic and Roman periods, parallel to the city but not necessarily subordinate to it, Dignas (2002a), esp. 243 regarding Panamara and Dignas (2003); see also Laumonier (1958), 417 on Hekate's key as a symbolic remnant of a theocratic system. Dignas is right to point out that the priesthood was not just any civic office, but one with distinct honors and privileges. In Stratonikeia, however, the priesthood appears wholly integrated with the fabric of the polis, rather than as a separate or autonomous entity, although priests could certainly enjoy a wide range of latitude. 
have targeted this group in particular to shoulder the financial burden of the festivals. The transitions were certainly marked in the later Roman period with 'succession of the crown', accompanied by gifts of oil to the population. ${ }^{168}$ And yet to counterbalance this image, it should be observed that the priesthoods were annual and that they were not restricted to a particular family, even though the same names frequently occur. The priesthood was in fact fulfilled by citizens from all across the territory of Stratonikeia, as all five of the major demes are represented in the demotic of their names. ${ }^{169}$ In the imperial period, the priests often occupied the role of gymnasiarch at least during the Panamareia, probably as a way to ensure the smooth running of the festival in which events such as the distribution of oil took place in the gymnasium and other places in and around town. ${ }^{170}$ Although it continued to gain prestige, the priesthood of Zeus Panamaros, and that of Hekate at Lagina for that matter, should not be seen as a pseudo-independent source of power and authority but instead as an office fully in line with the needs of the polis - the polis was after all, at the center of the festivals of both gods and the priesthood one of its prime institutions.

Priests clearly took on the role of urban producer, even more so in the imperial period: they maintained the social fabric by addressing the entire population, while reinforcing the categorical differences (e.g. their generosity was extended even to the 'foreigners' and 'slaves' etc), treating some differently (e.g. special banquets for the gerousia, the different sums of money given to men or women), but especially by creating a level of social dependency on them and

168 Over twenty inscriptions, dated to the later second and third centuries, mention $\tau \hat{n}$

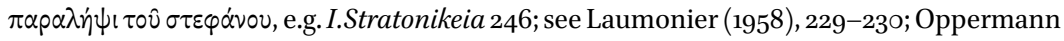
(1924), 57 .

169 Van Bremen (2004b), 239 observes that the earliest priests came from Koraia and Koliorga; these communities have not yet been identified, and so she suggests therefore that these villages were located close to Panamara, and that they were used to incorporate the Panamareis. She then goes further to state "instead of a takeover of the periphery by the centre, we see a very slow transition, within the wider polis context, from a domination of the priesthoods by those who lived in the sanctuary's vicinity, to a more evenly distributed participation across the whole territory later in the Roman period." This idea is attractive but must remain hypothetical until the locations of Koliorga and Koraia are known; none of the suggestions presented until now are particularly close to Panamara, even on Debord's map in Debord (1994), endorsed in van Bremen (2004b), 215. See above, in Chapter 5, Figure 5.1, and note 28, for Koliorga and Koraia, and note 54 of this chapter on Koraia.

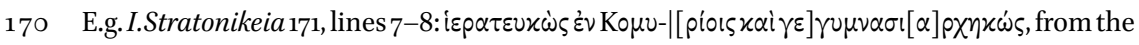

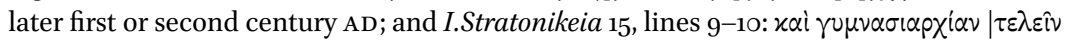


ond century AD. See also Hatzfeld (1927), 67 n. 3 . 
their position, all under the 'veil' of the sacrifices, as Richard Gordon puts it. ${ }^{171}$ Interpreting the euergetic system as a balance of power within the empire, Gordon shows how priests personally made heavy investments in the community, and in return received a high degree of social capital, thus perpetuating the "unequal and steeply stratified society."172 As one of the central institutions of the polis, the priesthood occupied a role of dynamic integration that worked both horizontally and vertically.

Besides the priests, another important sacred official at Panamara was the neokoros, a sort of financial administrator or manager of the sanctuary. This role is attested only once in an important but fragmented decree, now dated to the first century вс, regarding a manifestation of Zeus and the resulting privileges of asylia and ateleia; the neokoros is responsible for producing the inscription itself. ${ }^{173}$ All of the other instances of the neokoroi occur in the imperial period and show that the office is often fulfilled by someone who had been priest before and was probably able to offer guidance or financial assistance to the incumbent priest. ${ }^{174}$ The later imperial period shows a number of other incidental offices at Panamara, including the mystagogue, who presumably officiated at the mysteries of the Komyria. ${ }^{175}$

\subsubsection{Local Community - The Koinon of the Panamareis}

The Panamareis left sporadic indications of how their koinon was organized. Their decisions were taken in a community council, the ekklesia, convening under a demarchos. ${ }^{176}$ The community granted proxeny to a Rhodian citizen,

171 Gordon (1990), who interprets priesthoods in the empire as a repetition of the pattern of dominance at various scales, beginning with the emperor and working down to the local "peripheral" level. His example on p. 226-228 of Kleanax, son of Serapion of Kyme, is a striking parallel: as prytanis, Kleanax spent lavish sums on feasts for a highly diversified community - citizens, Romans, paroikoi, and foreigners - whose divisions "are repeatedly rehearsed, in an almost incantory manner," p. 228 (SEG 32 1243).

172 Gordon (1990), 208. Gordon sees the priesthood further as a critical hinge between the polis and imperial rule; although it extends beyond the focus of this present research to examine this at length, the adjectives 'loving the emperor', 'loving the fatherland', and sometimes even 'loving the Romans', as well as 'son of the polis', are liberally applied in the hiereus inscriptions of especially the second century AD, e.g. I.Stratonikeia 189 describes

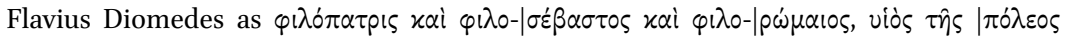
(lines 2-5). These affective usages are addressed in van Nijf (2014).

173 I.Stratonikeia 20 ; for the date see van Bremen (2004b), 22 .

174 Laumonier (1958), 231-232.

175 See Laumonier (1958), 232-233, where he also mentions a bouthytes, a specialist to help with the sacrifice of ten oxen (I.Stratonikeia 6o).

${ }_{176}$ The ekklesia and ekklesia kyria appear in I.Stratonikeia 4 and 9. The earliest inscription, I.Stratonikeia 1400 (= EA 35 (2003), 12-14) is an honorific decree for King Ptolemy, son of 
and extended citizenship (politeia) on at least two occasions, for a Rhodian commander as well as for the priest Leon in the second century вС. ${ }^{177}$ This shows their sense of autonomy, but is not necessarily proof of complete independence; the syngeneia of Korris also extended citizenship at Labraunda while being citizens of Mylasa themselves. ${ }^{178}$ As discussed above, the date of Stratonikeia's incorporation of the sanctuary, including the koinon of the Panamareis is unknown, but Riet van Bremen's hypothesis that it was a slow process, drawn out over some generations, is very likely the case. ${ }^{179}$ At any rate, after the sanctuary was clearly within the administration of the polis, the Panamareis were not heard from again. They may have become a deme of Stratonikeia, but more likely the community was divided among the other demes. ${ }^{180}$

Presumably the Panamareis resided near the hilltop of the sanctuary, since they took their name from the cult; they may well have been a dispersed or composite community, made up of smaller communities, who used the sanctuary as their central meeting place. ${ }^{181}$ Şahin did find evidence in 1975 of a settlement "... with comparatively well-preserved buildings located on a hill north of Panamara, just about $2-3$ kilometers away. The settlement is larger

Ptolemy, and is restored as being dedicated by the Panamareusi, which is taken to indicate that the Panamareis considered their community as a polis; see the discussion on p. 9-10 of I.Stratonikeia 140o. The demarchos is mentioned in I.Stratonikeia 6; van Bremen discusses this position in van Bremen (2004b), 231 n. 85; see also Oppermann (1924), 25-30.

177 I.Stratonikeia 5,6 and 7 , respectively.

178 On the Korris syngeneia see I.Labraunda 11-12, and above Chapter 3, Local community. These features are seen as an indication of Panamara's "autonomy" by Oppermann (1924), 24-31; Debord (1994), 114; Gabrielsen (2000), 163-167. One might also wonder what 'autonomy' meant, when they were clearly dependant upon the persons whom they were honoring. Van Bremen assesses Panamara's later "autonomous behaviour" with regard to the priest Leon as operating under the shadow of Stratonikeia, van Bremen (2004b), 228-231.

179 Van Bremen (2004b), 231, 235-240.

180 Panamareus rarely appears as a demotic, and then in imperial contexts, e.g. in I.Stratonikeia 615, a priest who was the adopted son of Phanios of Panamara; in I.Stratonikeia 227, the priestess Ada from Panamara; in I.Stratonikeia 846, a priest Damonikios, son of Herodos of Panamara - this last inscription was found at Akçahisar, which Şahin believes may have been the site of Londarga (or Lobolda), see Şahin in I.Stratonikeia III, p. 7-8. Laumonier lists Panamara among the demes of Stratonikeia, Laumonier (1958), 197-199, but Şahin believes it may have become a phylai of the polis, Şahin (1976), 37-38; see also van Bremen (2004b), 238-239.

181 Şahin is convinced that the koinon of the Panamareis was a federation of villages, Şahin (1976), 24 n. 78 and $24-25$. 
than what we know of Panamara."182 Laumonier had also noted the remains of a settlement "très ruinés en petites pierres," roughly 1.5 kilometers northwest of Panamara. ${ }^{183} \mathrm{He}$ describes in detail how this is situated along one of the lower slopes above "Bayaka Ova," where the ruins straddle a small ravine and extend for no more than 200 meters. Laumonier observed the foundations of a structure on one of the hilltops, at 30 meters long and 15 meters wide with a bastion or gateway projecting seven or eight meters along the north side. A rock-cut tomb, with a ledge for the lid, was situated in the terrace overlooking the bastion. Just below this was a structure built with Cyclopean walls, measuring eight by five meters. The hilltop further to the south also seems to have contained remains of Cyclopean walls. One follows an ancient road from here to Panamara, three meters wide for over 5 oo meters in embankments on the side of the mountain, along a deep ravine that separates this area from the spur on which Panamara sits. ${ }^{184}$

Laumonier's description is highly intriguing, since the area has not otherwise been systematically surveyed for any evidence of settlement activity, and may never be in light of the strip-mining activities. The proximity with the sacred way surely indicates that this complex was connected with the shrine, perhaps the settlement of the Panamareis, or a later community of cult personnel. If the saddle that Laumonier mentions is the same one on the lower eastern slope of the Bencik Dağı, at an elevation of roughly $730 \mathrm{~m} \mathrm{ASL}$, then it would have visually encompassed most of the territory of Stratonikeia, connecting it with Panamara. A number of tombs, cut from the rock, may now also be observed along the western approach to the sanctuary, marking the course of the sacred way (discussed above, also Figures 6.24-6.25). Since these have 'informally' been brought to light, their chronology will unfortunately remain unknown, yet they strongly resemble the description of the tomb seen by Laumonier in the nearby settlement.

One inscription from the first century BC mentions those who were physically at the sanctuary (the entopioi), local residents that may have worked the lands in the area or kept herds, or possibly cult personnel; their identity

\footnotetext{
182 Şahin in I.Stratonikeia III, p. 13; he discusses this in connection with I.Stratonikeia 1402, since he considers this site a candidate for the village of the Laodikeis, see above.

183 Laumonier (1936), 324. Unfortunately the exact location of the site was not recorded, and I was unable to identify it during my visit in October 2011. It seems likely that it would be situated on the ridge immediately north of Bağyaka - this ridge, however, has been given over to the exploitation of lignite (see Figure 6.7) and as Bağyaka has recently been evacuated, there was no one left in the village to ask.

184 Laumonier (1936), 324-325. The known extent of the road is described above under Sacred road.
} 
is unclear. ${ }^{185}$ If the marble doorway that now lies exposed on the northwest slope (Figure 6.26) was indeed part of a tomb, then it may well have belonged to one of the wealthier priests. For the rest we can only speculate as to whether the people buried near the sanctuary were locals, from one of the nearby settlements discovered by Laumonier and Şahin, or residents from town who wished to be buried near the sacred place. They were in any event not as highly profiled as a group as were the katoikountes, or residents, at Lagina.

\subsubsection{Economic Resources}

The sanctuary of Zeus at Panamara had become a large and extended complex with festivals which must have required a significant financial undertaking, and yet our knowledge of its economic base is poorly informed, as it is at Lagina. Whether the polis had a sacred treasury or reserve for the festivals, or generated their own additional income through the events provided, or whether the sanctuary owned lands that were exploited can only be speculated.

In fact, the only source of income explicitly mentioned is provided by the priests themselves, as they personally host banquets, and give out gifts of oil, wine, and money. These banquets and distributions for the entire population would have provided a significant impulse for the local economic production systems. As the distributions took place throughout the chora, they also would have been another means of shaping the territory through cult while creating social cohesion at the same time. One hiereus inscription from the later imperial period explicitly mentions those living in the city and of the chora, in reference to the Heraia. ${ }^{186}$ Several hiereus inscriptions mention distributions of oil to both citizens and strangers during the festivities. In I.Stratonikeia 310 , shows a prominent priestly couple, distributing gifts in the processions and festivals of the Panamareia as well as Hekate's kleidos agoge, and even providing crowns that were given out during the 34 days of festivities in that year. ${ }^{187}$ Certain segments of the population were frequently singled out, e.g. the women of the city

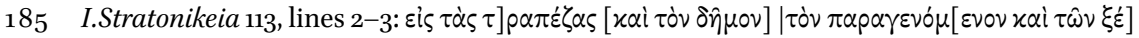
$v \omega \nu$ xal zे $[\tau \circ \pi i \omega v]$.

186 I.Stratonikeia 256, discussed above under Festivals, n. 91 and n. 110. Also I.Stratonikeia 268.



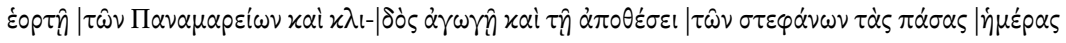

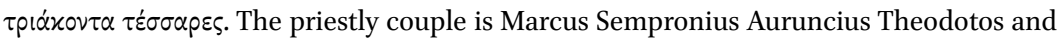
Sempronia Auruncia Arriane, briefly discussed above under Administration and priesthoods; see also above in Chapter 5 , note 228.
} 
and countryside who each received gifts of three drachms, ${ }^{188}$ and the Romans living in the countryside. ${ }^{189}$

While they no doubt fulfilled a real need of the population, these distributions also created a kind of financial dependency, meanwhile generating social capital for the priests themselves. ${ }^{190}$ In any event they underscore the role of the priest as civic producer, creating or maintaining cohesion among the population as well as territorial integrity by using their personal generosity to ensure that the cult and with it the polis was the focus of the entire community.

To summarize, prior to the advent of Stratonikeia, the cult of Zeus at Panamara had been administered by the koinon of the Panamareis. The autonomy of this community, wherever they lived, is unclear, especially in the early second century вС, as they had to deal with Rhodes, Philip v (for a short time), and eventually the rising polis to the north. Riet van Bremen's view of a gradual transfer, in which the Panamareis retained their title to the sanctuary while Stratonikeia began to transform the cult from the inside out, seems most plausible. The appointment by Stratonikeia of Leon as priest is a turning point, at least in the epigraphic record. He clearly had the means and apparently the clout to revive the shrine and get other communities involved too, expanding the network of Panamara while gaining goodwill for Stratonikeia. Leon's strategy worked well, and the koinon even felt that he acted on their behalf, although this actually signalled the end of their administration. Several generations after Leon, another priest also acted as a broker when he personally invited several cities throughout Karia and Ionia to participate in the festivals at Panamara, thereby expanding the network of Stratonikeia through ties of syngeneia and cult. Priests were well-connected statesmen and were most likely included in the envoy sent by the polis to Rome to secure the Senatus consultum de Panamara after the miraculous rescue by Zeus from Labienus. By the imperial period, the euergetic dimension of the priesthood began to escalate into increasingly sumptuous displays of generosity, with gifts of oil,

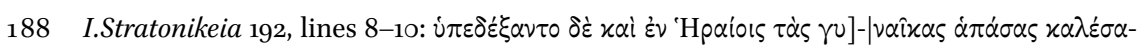

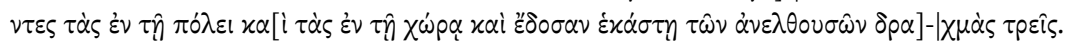
The priestly couple had also given the men five drachms each during the Komyria.

189 I.Stratonikeia 186 is an inscription by a priest who was 'pious towards the gods, having sought honor among the citizens, the Roman residents of the country, and foreigners'

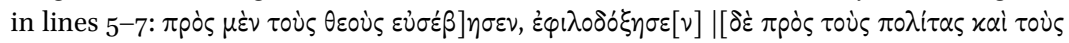

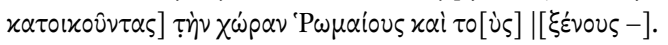

190 Laumonier suggests that the priestly gifts fulfilled a real need among the majority of the population which was poor, Laumonier (1958), 397; Gordon stresses how these gifts established a balance of social inequality, Gordon (1990), also discussed in Zuiderhoek (2009), 94-95 and Zuiderhoek (2011). On social capital, Bourdieu (1986); on the 'social turnover' turnover of euergetism, Zuiderhoek (2009), 133-140. 
wine, and money, as well as banquets and spectacles. This financial burden restricted the position to the highest circles of the urban elite and the office was frequently held by members of the same family in different generations. Some individuals held the position more than once, and some even combined it with the priesthood of Hekate at Lagina. As with the ritual, this overlap of religious domains would have contributed to the growing similarities between the two major cults of Stratonikeia. The priests also played a crucial role in turning the hilltop sanctuary at Panamara into a major urban complex by the imperial period. Most likely there was a local resident community, possibly at the site found by Laumonier on the lower slopes of the Bencik Dağg. ${ }^{191}$ As civic producers, the priests of Zeus, and Hekate, would have seen their euergetic function as a return on investment in the population of 'their' city, creating a communal focus while increasing their social capital. Social cohesion in this diverse population base would have been critical to the stability of the polis. As at Lagina, the priesthood at Panamara was one of the central institutions that helped build the territorial and social integrity of the polis. Priests were clearly central figures in constructing the urban identity of Stratonikeia. ${ }^{192}$

\subsection{Urban Mediatization at Panamara}

The architectural remains, the festivals and the administration of the sanctuary at Panamara have shown how the cult of Zeus was gradually absorbed by the polis of Stratonikeia. This section explores how the sanctuary was used to expand the political network of the polis, but also how the Stratonikeians perceived and expressed their own relationship with Zeus Panamaros, both in the stories they told to each other, but also to the outer world, and in the ways they depicted him on their coinage. These show how the cult of Zeus had become an organizing principle and symbolic focus for the community, creating joint attention for the internal cohesion of the polis, but also for its external manifestation.

\subsubsection{Scope and Network}

The sanctuary of Zeus at Panamara has already been demonstrated to have had a regional significance through the involvement of the surrounding

191 The many tombs lining the sacred road to the sanctuary resemble the one described by Laumonier at the settlement which he discovered and could be from locals or pilgrims. On the settlement, Laumonier (1936), 324-325, cited above under Local community. Whether this is the same site mentioned by Şahin in I.Stratonikeia III, p. 13, which he saw in 1975, is unknown and is unlikely to be verified, since the wider area around Bağyaka has been given over to the Yatağan Power Plant, see above Figure 6.7.

192 Developed more in Williamson (2013b). 


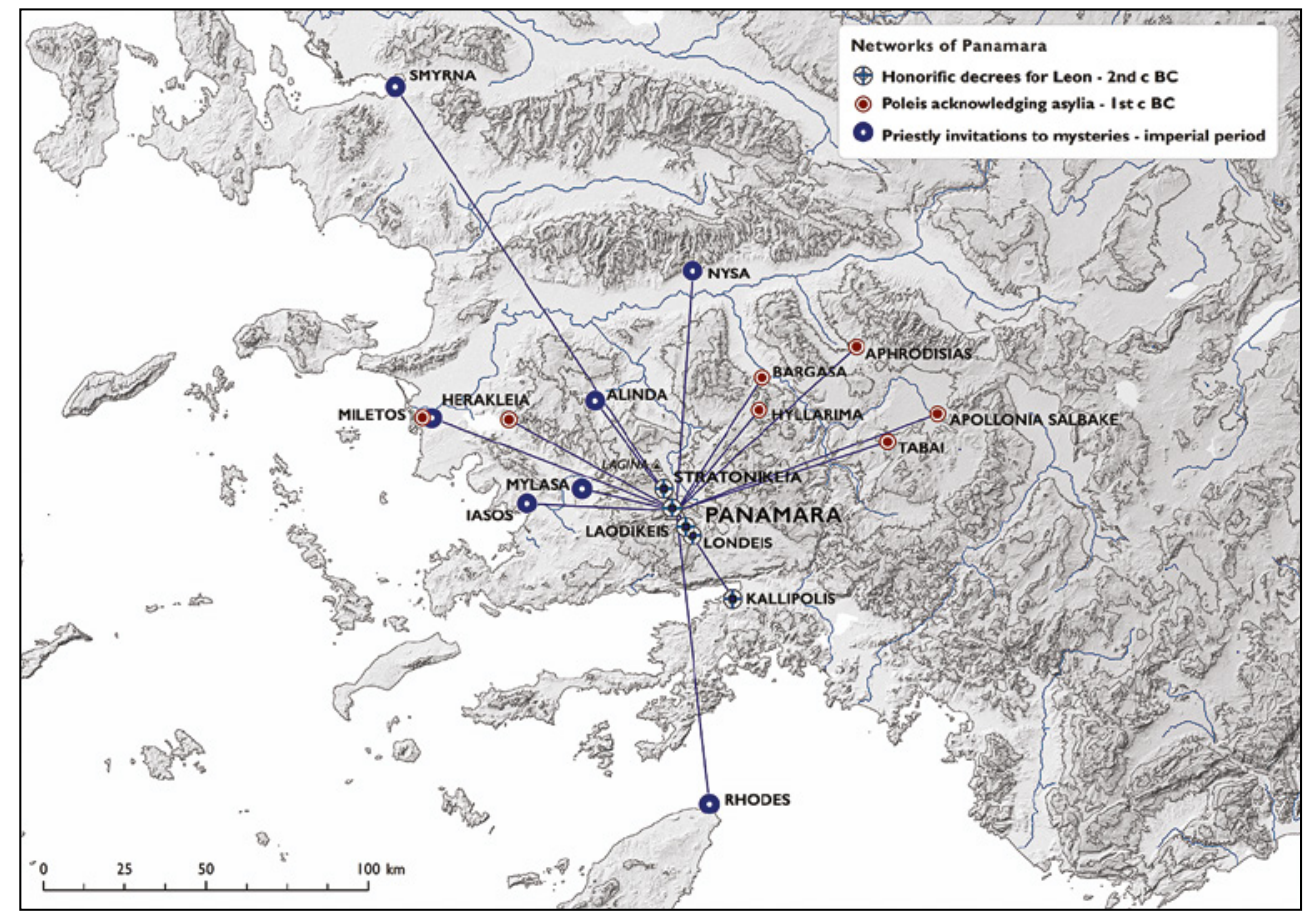

FIGURE 6.28 Social network of Panamara. Map of the identifiable communities involved in the worship of Zeus at Panamara at different times, testified by inscriptions

communities, as well as the attraction it had for Philip v and the Rhodians, both honored by the Panamareis. As discussed in the previous section, priests played an important role in shaping the cult of Zeus at Panamara. Besides their religious function in defining the ritual performances, they also had a political role as actors in extending the urban relations of Stratonikeia through expanding the cult network. This was done in at least three separate periods at Panamara.

The first period of network expansion occurred at the initiative of Leon, assigned by Stratonikeia as priest of the cult of Zeus Karios at Panamara. Communities that we know were active at the sanctuary at this time include the Londeis, the Laodikeis, and the town of Kallipolis, all located to the south (Figure 6.28). Leon exhorted these communities, and others, including Stratonikeia, to acknowledge the (rediscovered?) ancient right of asylia at the sanctuary and to augment the splendor of their sacrifices. Not only did Leon address these communities individually, he also 'achieved a settlement between those who disagreed about the oath', getting them to 
cooperate again. ${ }^{193}$ Nothing is otherwise known of the nature of this oath, or the disagreements, but oaths were a normal part of any human transaction, not only with the divine but also, and especially, between humans as a kind of binding contract. ${ }^{194}$ This oath was most likely central to the operation of the cult network at Panamara, since it is the main reason for the gratitude of the Kallipoliteians and the Laodikeis; smoothing out some of the issues that these two communities both had with the text reinforced the network by ensuring their full cooperation.

In this way the sanctuary once again became a lively center of activity and a bright dot on the mental maps of the surrounding communities. Although we do not know the exact nature of the relationship between Panamara and Stratonikeia at this time, the fact that the young polis was able to appoint a priest at the sanctuary is in itself significant. Leon's priesthood belongs to a period of transition at both Stratonikeia and Panamara, when the shrine was probably within the area liberated from Rhodian rule by Rome in $167 / 6$ вC, along with Stratonikeia, but connected to communities that were still within Rhodian territory, farther to the south. ${ }^{195}$ Rhodes was known to feel 'hatred' (apechtheia) towards Stratonikeia in this period, and the emphasis of Leon's actions as being conducted at personal risk may well have to do with this venture into hostile territory. ${ }^{196}$ Panamara was at the northern edge of this area,

193 The decree of Kallipolis mentions the oath in I.Stratonikeia 1401, lines 12-13: [- xai tov̀

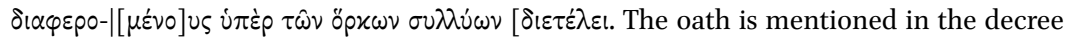

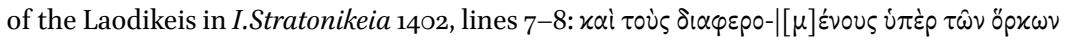
$\sigma 0 \lambda \lambda \dot{\omega} \omega \nu \delta \varepsilon \varepsilon \varepsilon \dot{\lambda} \lambda \varepsilon \mathrm{l}$. Translations of the texts in full are provided in van Bremen (2004b), 241-244. On oaths in general, Williamson (2013a).

194 On Panamara as a center for solving legal problems: Chaniotis (2004), 30-31. On oaths as social contracts: e.g. Bederman (2001), 67-68 and Carawan (2007).

195 The date of Leon's priesthood has been the object of some discussion, see above under Administration and priesthoods, but is now seen as following the liberation from Rhodes by Rome in 167/6 BC; van Bremen (2004b), 209-210. Van Bremen (2004b), 236-237, sees this as reason for the Laodikeis to refrain from stating Leon's origin; they continued to date their decrees according to Rhodian priesthood, showing its dependency, while Rhodes was known to be antagonistic towards Stratonikeia.

196 Rhodes' hatred of Stratonikeia is expressed in I.Iasos 612, discussed in Ager 1996, no. 161; this concerns a (territorial?) dispute between Rhodes and Stratonikeia, arbited by a citizen from Bargylia, dated to the later second century вс, during the Aristonikos wars. The emphasis on Leon's personal risk is in pursuing the interests of Zeus and the Panamareis is shown in I.Stratonikeia 7 , lines 9-11 (cited above). The inscriptions of Kallipolis (I.Stratonikeia 1401, line 15) and the Laodikeis (I.Stratonikeia 1402, line 9) also acknowledge his effort and potential hardships and personal investments. Similar phrasing is used at Keramos in a decree honoring an unnamed citizen, roughly in the same period, who acted in the interests of the polis during a sympoliteia, without regard for personal risk 
and apparently welcomed support from the expanding polis to the north, just as the polis was clearly eager to include the sanctuary within its wider radius of action. Increasing the fame of the sanctuary would reflect well on the polis that held it within scope. Van Bremen sees, however, an ulterior motive behind Stratonikeia's mounting influence at the sanctuary: promoting goodwill at the sanctuary among its constituent communities in the south was a way of creating a friendly corridor through hostile Rhodian country towards the coast, with all its strategic and economic attractions. ${ }^{197}$

A second phase in the expansion of the cult of Zeus at Panamara followed the attack by Labienus on the sanctuary in 39 BC. An inscription at the temple, discussed in the next section, shows how the assault was miraculously thwarted by Zeus - this gave the Stratonikeians reason to appeal to Rome for a second grant of asylia, or inviolability, this time for Panamara, and Laumonier believes that a number of the names of the Stratonikeian ambassadors to Rome probably belonged to families of priests. ${ }^{198}$ Parallel to Leon's actions, and parallel to those at Lagina 42 years before, the grant of asylia, written in the Senatus consultum de Panamara and inscribed on the walls of the temple, ${ }^{199}$ was again used to compel other poleis to acknowledge the status of the sanctuary and per association the corresponding city. The process of gaining this recognition is unfortunately unknown, but a heavily fragmented list of cities from this period may indicate its success. ${ }^{200}$ The only cities whose names were preserved - Miletos, Apollonia (Salbake), Aphrodisias, Tabai, Herakleia, Hyllarima, and Bargasa - are located in central and eastern Karia, with the exception of Miletos (Figure 6.28). This represents a second wave of expansion of Panamara's network to the north and northeast, very likely related to

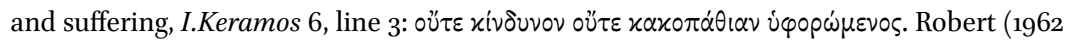
[1935]), 6o-61 suggested that the sympoliteia may have been with Stratonikeia, see also Debord (2001a), 165; van Bremen (2004b), 211 n. 18, however, doubts this interpretation but does acknowledge the risks that such endeavors apparently involved, testified by this inscription.

197 Van Bremen (2004b), 217-218: "The entire subject-Peraia [= Rhodian territory on the mainland - CGW] formed a buffer between Stratonikeia and the sea, with Rhodian dominated koina on either side of the main route along the valley of the Marsyas down to the sea at Idyma; the same applied for the alternative route via Pisye along the valley of the Kartal Deresi (Kocaçay) down to Sarnıç and to the sea at Akbük, which was moreover lined with fortresses." See also van Bremen (2004b), 218, n. 37-38.

198 Laumonier (1958), 239.

199 I.Stratonikeia 11-12, see also Sherk and Viereck (1969), no. 27, 158-162. This is discussed in the next section.

200 I.Stratonikeia 21. Hatzfeld suggested that this list was related to the asylia, Hatzfeld (1927), 68. 
its grant of asylia in the later first century вс. The asylia was in any event used again later to get Rome's attention at the reforms tribune of Tiberius in $23 \mathrm{AD}$, and Stratonikeia was among the rare exceptions to boast two sanctuaries with this privilege. ${ }^{201}$

In the early imperial period, perhaps at the end of the first century BC, another unknown priest took the initiative to send invitations to a number of cities to participate at the sanctuary. ${ }^{202}$ Hatzfeld observed that the objective was to get as many of the surrounding poleis as possible involved with cult activities. $^{203}$ The eighteen letters that survive point to a third wave of the social network of Panamara, but unfortunately only seven names have been preserved: the Rhodians (including those living in Karia), Mylasa, Alinda, Iasos, Miletos, Smyrna, and Nysa (which was already participating in the festivities of Hekate). Mylasa as nearest neighbor is significant while the rest roughly border on the wider region of Karia and Stratonikeia in particular (Figure 6.28). Interestingly, the letters stress a mutual (but surely invented) ancestral bond, i.e. syngeneia, referring to the sacred things which they held in common, as well as homophily, friendship and goodwill. ${ }^{204}$ The shared heritage was presumably stressed in order to strengthen the ties with these communities, obliging them to take part in the cult and mysteries. ${ }^{205}$ Although the events leading to this correspondence are unknown, a wider participation would have not only given a boost to the local economy through additional sacrifices, but also a heightened profile of the sanctuary in the region, as well as the creation of a friendly buffer zone around Stratonikeia's territory.

201 Tac. Ann. 3.62, cited above in Chapter 5. Rigsby (1996), 418-427 on the grants of asylia for Stratonikeia. He observes on p. 418 that "Pergamon supplies a parallel for this double achievement [for the sanctuaries of Athena Nikephoros and Asklepios - CGW], and perhaps Chalkedon."

202 I.Stratonikeia 22 through 39b, mentioned above under Administration and priesthood. They are discussed in Hatzfeld (1927), 71-73, and at length in Curty (1995), 167-175. Syngeneiai, or kinship groups, are discussed in more detail in Chapter 4 in relation to the Pelekos and Pormounos syngeneiai of the sanctuary of Sinuri.

203 Hatzfeld (1927), 72.

204 E.g. I.Stratonikeia 22, the letter to the Rhodians, refers to their cities as $\pi$ pòs $\alpha \lambda \lambda \dot{\eta} \lambda \alpha \varsigma$

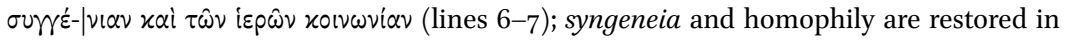
I.Stratonikeia 3o, the letter to the Mylasans, which also includes friendship and goodwill (lines 3-4). On using syngeneia as the base for establishing ties in a network, see esp. Curty (1995), Jones (1999), Lücke (2000), Ma (2003), and Erskine (2003).

205 John Ma presents a parallel usage of syngeneia, by the Kytenians of Greece, who, after suffering earthquakes and wars in the early third century BC, decided to obtain external funding to rebuild their city walls; they did so as true Dorians and asked for contributions from other Dorian-related cities based on syngeneia; $\mathrm{Ma}$ (2003), 9-12. 
Most scholarly opinion places these letters in the second half of the first century BC, probably after the epiphany of Zeus. ${ }^{206}$ If this is true, then there may have been yet another priest who followed in Leon's footsteps by getting the surrounding communities more involved in the cult. Curty suggests as much, and goes even further by stating that it was through the sanctuary at Panamara that Stratonikeia was able to expand its orbit. ${ }^{207}$ Whenever they were written, these letters were critical in creating ties between the polis and the wider region through the sanctuary of Zeus; Ma, in fact, speaks of the discourse of syngeneia as a symbolic map, establishing links with communities in distant regions. ${ }^{208}$ These letters inscribed at the sanctuary thus functioned as a kind of map of places that were important to Panamara and to Stratonikeia. Using asylia to create geopolitical ties was a strategy that Stratonikeia was well familiar with. This had already been used at Panamara to draw in the surrounding communities, much as it had been done at Lagina in the early first century BC - both sanctuaries clearly played pivotal roles as major hubs in the wider political network of Stratonikeia.

\subsubsection{Civic Decrees}

Panamara was a good place to establish political ties. Long before Stratonikeia used the sanctuary to solidify its position in the area, the koinon of the Panamareis used it as their own political platform; they issued a decree to honor Ptolemy apparently even before the Seleukid foundation of Stratonikeia. ${ }^{209}$ Later decrees by the Panamareis show them honoring Philip v, who used the citadel as his base for occupying the region at the end of the third century вс. ${ }^{210}$ They also used the sanctuary to honor Rhodians when they were in control, similar to Stratonikeia's use of Lagina. ${ }^{211}$ I.Stratonikeia 6, for example, is a decree

206 Hatzfeld (1927), 71-73, and Curty (1995), 173-175. Especially the invitation extended to Rhodes is an argument against dating these letters to the period just after the independence of Stratonikeia from Rhodes, since Rhodes is known to express 'hatred' ( $\dot{\alpha} \pi \dot{\varepsilon} \chi \theta \varepsilon 1 \alpha)$



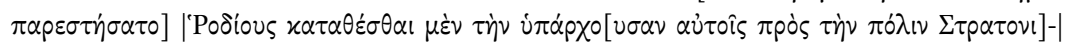
$[\chi] \hat{\eta} \omega \nu \alpha \dot{\alpha} \pi \dot{\varepsilon} \chi \theta \varepsilon ı \nu$, dated to 127 BC.

207 Curty (1995), 175: "Ce sont les légendes de cette Confédération [the ieron koinon in the text] qui permettent de rattacher à Stratonicée des cités dont les mythes ressortissent à des sytèmes fort différents."

$208 \mathrm{Ma}$ (2003), 9-12, 20; discussed above and in Chapter 2.

209 I.Stratonikeia 1400 , dated to the $270 \mathrm{~B} \mathrm{BC.}$

210 I.Stratonikeia 3 , dated to 201 BC; I.Stratonikeia 4 is an honorific decree for Philip's epistates Asklepiades of Peuma, dated to 198 вс.

211 At Lagina this included the cult to Rhodian Helios, I.Stratonikeia 504, and a reference to an alliance between Stratonikeia and Rhodes in I.Stratonikeia 1418 (= EA 35 (2003), 
of proxeny by the Panamareis, which was to be set up in the sanctuary in 'a conspicuous place' (toi epiphanestatoi topoi). ${ }^{212}$ This in itself implies that the sanctuary had some kind of coherent design, although we do not know what this was, and that certain spaces were clearly more in the eye of the public than others. ${ }^{213}$

The honors awarded to Leon, the priest appointed by Stratonikeia, may well represent homage being paid to the rising power of the polis by the koinon. ${ }^{214}$ This is the last act by the Panamareis that we know of, and it signalled the irreversible shift of the center of gravity at the sanctuary towards the polis - the koinon of the Panamareis is not heard from again. The relationship between the sanctuary and the young city before this period is somewhat clouded. As stated above, the Panamareis seem to have used the stephanephoros of Stratonikeia to date its decrees during the occupation by Philip v. This at least indicates the polis as an administrative center for the area, but whether it actually controlled the sanctuary at this time is another matter. ${ }^{215}$

Besides the Leon inscriptions, the first appearance of the polis at Panamara is in a decree by the demos concerning the sanctuary. ${ }^{216}$ This heavily fragmented inscription may well be Stratonikeia's own response to Leon's plea for increased involvement in the festivals, as it seems to acknowledge the right of asylia of Panamara.

Stratonikeian concerns initially seem to revolve around the organization of the sanctuary, as the record left to us mostly consists of simple inscriptions placed by the priests, all of whom seem to have come from the polis. Festivals were no doubt organized but we know very little of these, other than the inscription listing the sacrifices with music. ${ }^{217}$ Otherwise the use of the

1-7) and I.Stratonikeia 1424 (= EA 29 (1997), 98-99 no. 17); at Panamara a Rhodian commander, Plykratidas of Dailochos, was honored in I.Stratonikeia 9, dated to the 18 os BC by van Bremen (2008). Rhodians were also honored in I.Stratonikeia 5 and 6 . Analyzing the letter-types, van Bremen suggests that no. 6 dates to the earlier part of the third century вС, and no. 5 by analogy with no. 6 , van Bremen (2008).

212 I.Stratonikeia 6 , lines $15^{-16}$. On the date of this inscription, see van Bremen (2008), 1412-1413.

213 See also Williamson (2013a) on the installment of oath inscriptions at sanctuaries.

214 Leon is honored by the Panamareis in I.Stratonikeia 7 , discussed above.

215 The stephanephoros in I.Stratonikeia 4 is interpreted as Stratonikeian by van Bremen (2004b), 231, who further points out that both Panamara and Stratonikeia used Rhodian dating conventions during the Rhodian period.

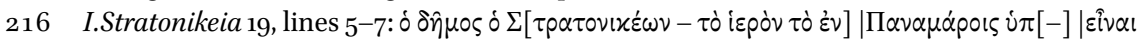
$\delta \varepsilon \hat{~ \tau o ̀ ~} \alpha$ $\sigma u[\lambda \circ v$; dated by van Bremen to the second century BC, van Bremen (2004b), 220. This decree was also meant to be set up in the 'most conspicuous place' ( $\dot{\imath} \nu \tau \hat{\omega} \iota \varepsilon \dot{\varepsilon} \pi \varphi \propto \nu \varepsilon-$

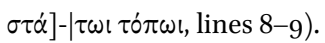

217 I.Stratonikeia 1, discussed above under Festivals. 
sanctuary by the polis appears rather low-key until the second part of the first century $\mathrm{BC}$ when events at Panamara mark an important turning point in the life of the polis.

In $39 \mathrm{BC}$, an account of the miracles performed by Zeus while protecting the sanctuary and people from attack by Labienus and his Parthian troops was recorded in detail in an inscription at Panamara. ${ }^{218}$ For the Stratonikeians it was this epiphany that saved their polis from the continuous onslaught by the Parthian troops - after the city had successfully resisted the assault, Labienus ransacked Lagina instead and turned to do the same at Panamara, probably during one of the festivals in which the population of the city was on the somewhat isolated hilltop. Unlike Lagina, however, Panamara was not taken thanks to the epiphany of Zeus, whose miraculous intervention day after day through fire, thunderstorms, fog, and hallucinations eventually brought total confusion upon Labienus's troops, who ultimately suffered heavy losses and fled into the Karian wilderness. All the while the lamps in Zeus's temple burned brightly, showing the god's presence. The long inscription relates the details of the event in vivid detail and color. Most likely this inscription was written into the walls of the very temple that withstood the attack, turning it into a lieu de mémoire.'219

This collective epiphany triggered a number of visible changes that mark a new phase in the relationship between the sanctuary and the city. In the first place is the inscription itself. As a monument, the record of the miracle was surely intended to imprint the event onto the collective memory of everyone who visited the sanctuary. But especially the way in which it is told, as directly as possible so that the reader is completely caught up in the event, holding his or her breath as they read on in suspense of how it will end, shows that this was also intended as real drama. Even the very reading of the inscription was a kind of re-enactment of the event. Like a legend, this event was meant to be kept alive through time, to be retold, reread, and relived each year by

218 I.Stratonikeia 10. This inscription is one of the few surviving accounts of an epiphany where so much detail is preserved (see also the Lindian Chronicles, and Pausanias's account of the epiphany at Delphi during the Gallic invasions, Paus. 10.23.1-10). It further describes the general setting of the sanctuary, its fortress, and the topographical difficulties Labienus's troops encountered in their attack, including the steep sides of the ravine. Further discussions in Oppermann (1924), Roussel (1931), Merkelbach (1968). Graf (2004), 118-122 observes that collective epiphanies typically involve meteorological phenomena rather than anthropomorphic manifestations; also Pritchett (1979), 11-46 on military epiphanies.

219 Deschamps and Cousin (1888a), 104. On 'lieu de memoire', Nora (1984-1992), also van Nijf (2000), $3^{2}$ and n. 53 and Alcock (2002), 21; see the discussion in Chapter 2 on Spatial memory and visual regions. 
each generation. ${ }^{220}$ The stealth attacks, the battles, the hail, fire and fog, the anguish of the people, and the final triumph, this was true spectacle, and the inscription ensured that everyone's imagination was thoroughly engaged in reliving the way in which Zeus protected the polis of Stratonikeia.

The second spin-off was the sizeable embassy, of 10 to 12 Stratonikeians, that was sent to Rome to remind the superpower once again of the city's loyalty and apply for asylia. By attacking the Stratonikeians through its shrines at Lagina and Panamara, Labienus could not have made the tightness of the bond between the city and its outlying sanctuaries mor clear; the Stratonikeians now used this same relationship in their to appeal to the Senate. They were surely also eager to 'update' the sanctuary's ancient right of asylia to make it current in the modern world. The acquired grant, in the Senatus consultum de Panamara, ${ }^{221}$ dated to August 15th of 39 BC, enabled Stratonikeia to again appeal to the wider community for recognition, while distinguishing the polis among its peers as a city with not one but two sanctuaries that were each officially declared inviolate.

A third important spin-off is the change in the epiklesis of the god from Zeus Karios to Zeus Panamaros, which already appears in the inscription itself as the people shout 'Great is Zeus Panamaros'.222 This inscription marks one of the earliest uses of Panamaros that would eventually replace the older and more regional title. Renaming the god in this way is a highly conscientious act, and it can hardly be a coincidence that it occurred at one of the most critical moments in the history of Stratonikeia. ${ }^{223}$ Emphasizing the place of the cult through the epiklesis of Panamaros, rather than the wider scope indicated by Karios, was in effect a way of annexing that very sanctuary on that very hilltop a

220 On embedding epiphanies into local history, see Rostovtzeff (Rostowzew (1920)), who relates the records of epiphanies at Lindos with the Chersonesean honorific decree, IosPE $I^{2}$ no. 344. This late third century вС decree honors the historian Syriskos for writing down all of the epiphanies of the goddess Parthenos in relationship with the polis of Tauric Chersonesos, the Bosporan kingdom and the other important poleis. I am grateful to Vladimir Stolba who pointed this out to me.

221 I.Stratonikeia 11-12, heavily fragmented. See also Sherk and Viereck (1969), no. 27, 158-162; Rigsby (1996), 423-427. The embassy is discussed in Laumonier (1958), 239, who believes that members of some of the priestly families were among the delegates, as mentioned above.

222 I.Stratonikeia 10, line 13.

223 Contra Oppermann (1924), 85, followed by Magie (1950), 997-998, n. 34, and Laumonier (1958), 241, who believe the epiklesis switch was a resurgence of the indigenous cult, with 'Karios' initially used in Macedonian contexts to distinguish him from Greek Zeus. Laumonier believes that the epiklesis reflects a desire to emphasize locality above ethnicity, downplaying the ethnic connotations of Karios, Laumonier (1958), 241. 
half a day away from town. ${ }^{224}$ Nicole Belayche suggests that the topographical connotations of this new name, which emphasizes the locality while neutralizing its regional appeal, made the cult more accessible for Karians, Greeks, and Romans too. ${ }^{225}$ Using this new name brought along with it an immediate mental image of the event as well as a clear idea of the location of the sanctuary, but most importantly the tight connection with Stratonikeia and its landscape.

This is one of the main reasons to interpret the new festival of the Panamareia as one of the most important spin-offs of this critical event. The event itself showed Zeus as an important actor/agent who took initiative in the relationship with Stratonikeia, much like Hekate before. ${ }^{226}$ It was his divine will and power to protect the population of the polis, who were left exposed at his sanctuary. The logic behind the festival of the Panamareia, then, is that this relationship is taken one step further - the almighty god descends into town, entering the city on horseback, to be among his beloved community of worshipers. The period of intense feasting in and around town and the general celebration of the polis that followed the processions were shared by everyone - citizens, foreigners, the freedmen and slaves, thus cutting across social boundaries, and especially those of origin in the old communities.227 The culmination of the procession at the bouleuterion, and the later imperial portrayal of the choirs of youths singing hymns and waving branches, served to make this event in itself a grand spectacle that would create a shared focus for the entire community.

224 In this context it is interesting to observe the four golden footprints (ichni) that were dedicated at Panamara in the later third century AD, I.Stratonikeia 248, lines 14-15, cited above in Chapter 5 , n. 140. Perhaps, like the feet incised at the sanctuary of Hekate, these could be interpreted in relationship with the divine power manifested on earth in this spot, Dunbabin (1990). Presumably the four footprints belong to Zeus and Hera, perhaps matching the footprints of the priestly couple dedicating them.

225 Rivault (2018) and Belayche (2009) discuss the implications of the name after the miracle in I.Stratonikeia 10. Belayche considers Zeus Panamaros as a completely new and civic-oriented cult, but her suggestion that this is a separate deity, in a kind of synnaos theos relationship with Zeus Karios, seems less plausible than Debord's view of the new epiklesis gradually overtaking the old Debord (2001a), 167. This seems to be supported by the several dedications that include Hera with either Zeus Karios or Zeus Panamaros, although Panamaros appears much more often, see (Williamson $(2013 \mathrm{~b})$ and esp. $(2020 b))$. Belayche gives an interesting interpretation on the later twist in spelling, as $\Pi \alpha \nu \eta \mu \omega ́ p(\imath) \circ \varsigma$, which would set it opposition with Hekate's lunar focus, Belayche (2009), 203. Rivault focuses on the new epikleses of megistos and epiphanestatos, Rivault (2018).

226 Hekate's epiphany is discussed above in Chapter 5 , under Urban mediatization.

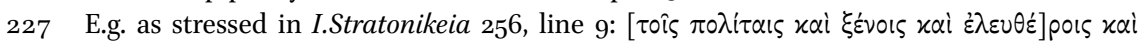
$\delta \circ u[\lambda \circ 1] \varsigma \pi \hat{\alpha} \sigma \mathrm{l}$. The festivals of the Komyria and the Heraia were similarly all-inclusive; see also above under Festivals. 
A final emanation from the epiphany of Zeus and especially the festival of the Panamareia is the change in his imagery on the coinage of the city, since Zeus begins to appear in the mid-first century ВС on horseback, continuing into the later imperial period (Figure 6.30); this is discussed in the next section.

All of these changes in the expression of cult and community through the festivals show the epiphany of Zeus to be a defining moment in the relationship between city and sanctuary. The polis may have institutionalized this relationship, but its origin was clearly presented as the divine will of Zeus Panamaros.

\subsubsection{Cult Iconography in Urban Contexts}

The appearance of Zeus at Panamara is only known from the coinage of Stratonikeia. Zeus and Hekate are portrayed on the earliest coins, issued some time after Stratonikeia's independence from Rhodes (Chapter 5 , Figure 5.27a). Andrew Meadows dates this group to the period between the 16 os and 13 os BC (Group 1). ${ }^{228}$ However, the identity of Zeus on these early issues is somewhat ambiguous. Meadows simply assumes that these coins show Zeus of Panamara, also for his Groups 2 (140/130-125/110 BC) and 3 (80s BC). ${ }^{229}$ Barclay Head had suggested an identity of Chrysaorean Zeus, the god of the Chrysaoric League, based on similarities with coins from Keramos, a member of the League. ${ }^{230}$ Both issues depict Zeus, bearded and laureate on the obverse, with an eagle on a thunderbolt on the reverse (Figures 6.29a-b). Comparisons with other poleis show that a similar laureate male bust with a beard is a rather generic depiction of a resident Zeus. ${ }^{231}$ In the absence of clear indicators it is impossible to conclude which Zeus is actually depicted on the earliest coinage.

Later issues, however, will have surely depicted Zeus of Panamara, as heavily involved as the polis was with his cult at that time. Although Zeus appears

228 Meadows (2002). Sources and interpretations of Stratonikeian coinage are further discussed in connection with Lagina, in Chapter 5 .

229 Meadows (2002), 98, without motivation for his identification of Zeus of Panamara, presumably assuming that Panamara already belonged to Stratonikeia in the period he gives for the first issues (160-13о вС).

230 Head in BMC Caria, lxix: "Whether these types refer to Zeus Chrysaoreus or Zeus Panamaros is doubtful, but the fact that the same types occur on the contemporary hemidrachms of Ceramus ... seems to indicate Zeus Chrysaoreus, whose cultus was common to all Carians ..." Keramos was a prominent member of the Chrysaoric League, Strabo 14.2.25 and Gabrielsen 2000, 159. Magie simply assumes Zeus Chrysaoreus, Magie 1950 II, 10311032, n. 77 .

231 Although Keramos, with Zeus on the obverse and an incuse eagle on the reverse, shows the closest parallels in its coinage with Stratonikeia, other similar curly-haired, bearded, laureate Zeus depictions appear on the Late Hellenistic coins from Euromos, Herakleia Salbake, Tabai, Myndos, and Orthosia. 


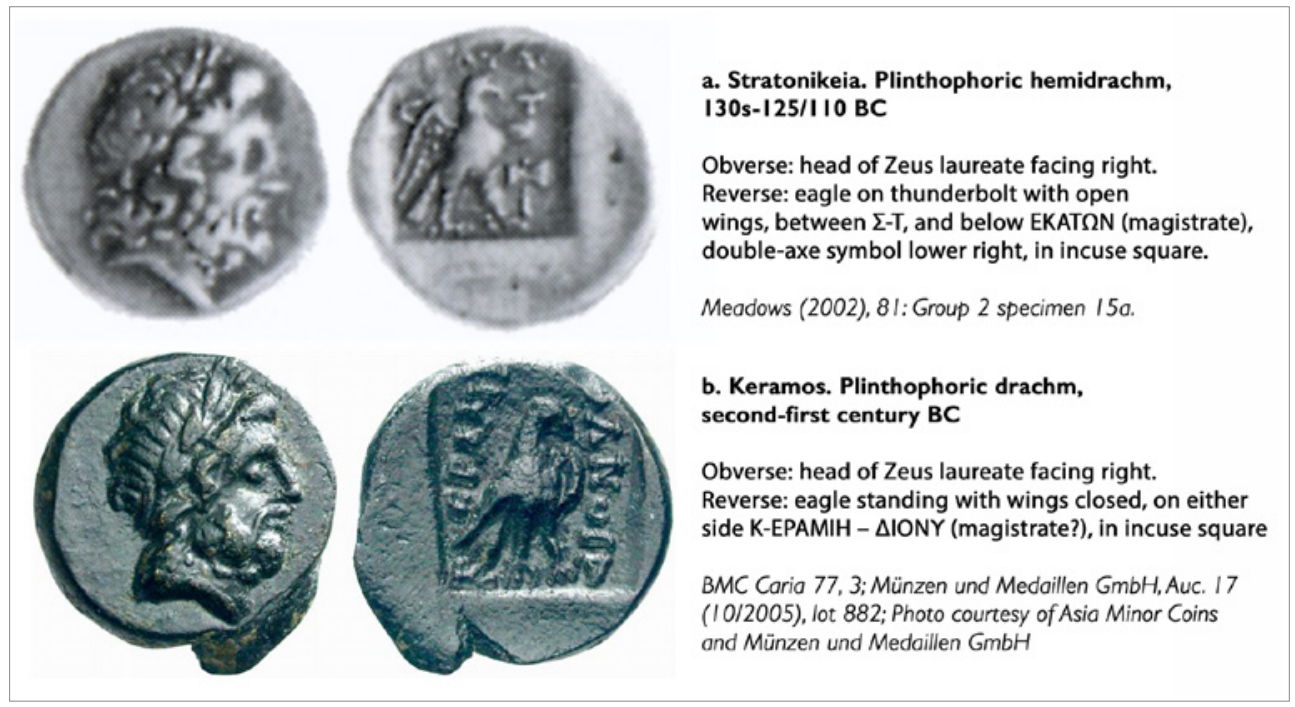

FIGURE 6.29 Zeus on coins from Stratonikeia and Keramos

less frequently than Hekate during the Mithridatic wars, he makes a strong comeback on the coins issued in the wake of the attacks by Labienus in 40 вС (Meadows' Group 4), now mounted on horseback (Figure 6.30a). ${ }^{232}$ This equestrian Zeus who surfaces on the coins after the siege by Labienus and the saving intervention of the god is widely interpreted as Zeus Panamaros. ${ }^{233} \mathrm{But}$ this is not the only occurrence of Zeus astride a horse; a contemporary coin from Apollonia Salbake shows Zeus with a double-axe (as Zeus Labraundos?) riding across a wall-like shape (Figure 6.30b). The aspect of an equestrian Zeus raises several interesting questions as to whether his cult actually began to converge with that of other all-powerful rider-gods, especially Sabazios from Thrace, whose cult was making inroads into Karia in this period, or whether the imagery was borrowed in order to convey a powerful god in contemporary terms that would be understood by all. ${ }^{234}$

On the Stratonikeian coins from this time on, Zeus on horseback must have been reminiscent of his epiphany and his regular appearance in the Panamareia (Figure 6.30a, c), assuming that his cult was brought into town on horseback in

232 Meadows (2002), 111-113.

233 See e.g. Head in BMC Caria, lxxii; LIMC VIII, 381 no. 116; this makes it especially tempting to project this interpretation back to the bearded heads on the earlier coins.

234 The Thracian equestrian god Sabazios is attested in Karia at different places, e.g. Pisye (Debord and Varinlioğlu (2001), 131) and Mylasa (I.Mylasa 34 and 330); the later coins of Attuda also depict Zeus Sabazios (SNG von Aulock 2495). On rider-gods see e.g. Johnston (1992); Delemen (1999); Horsley (1999); and Talloen (2006). 


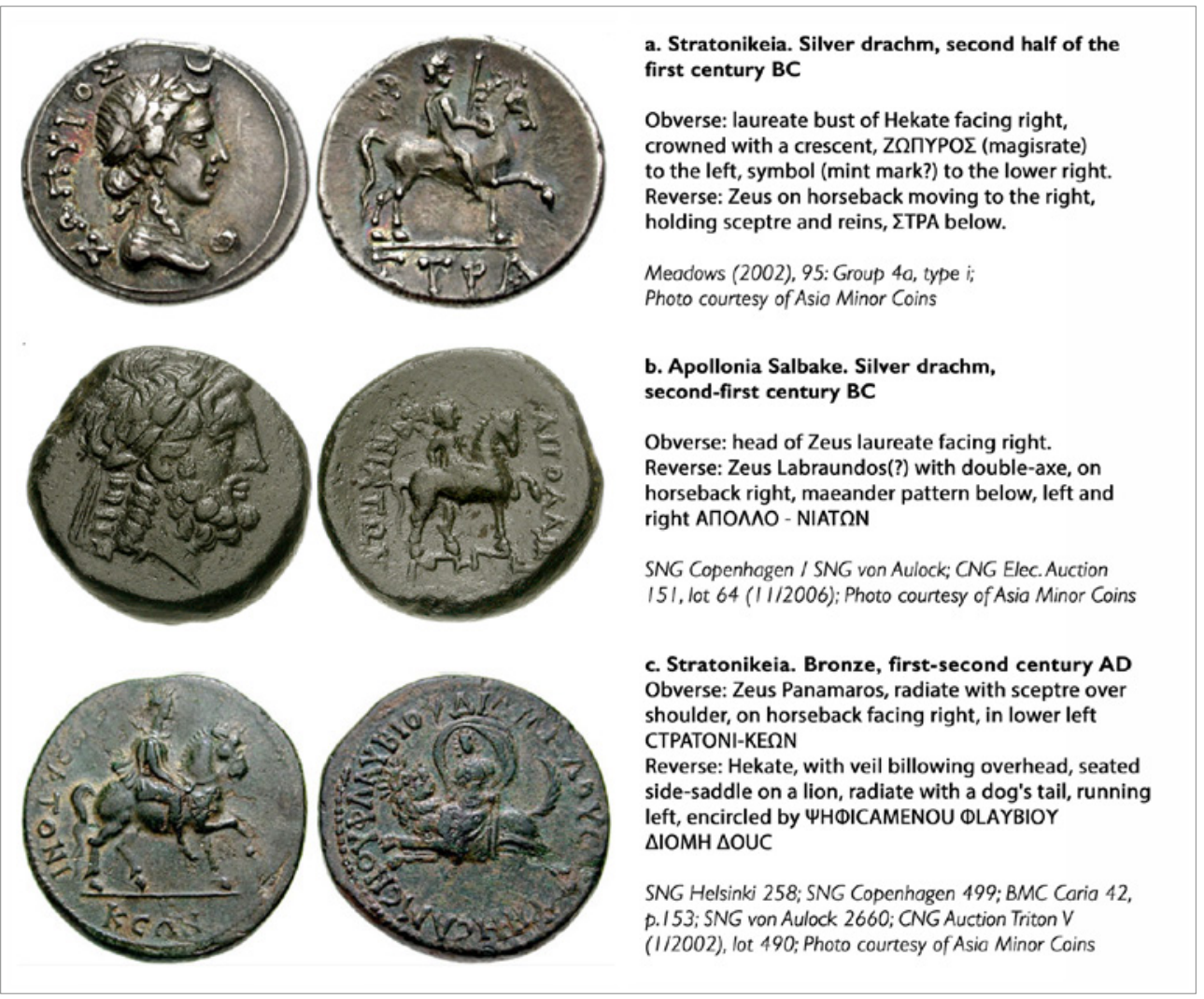

FIGURE 6.30 Stratonikeian coins showing equestrian Zeus and Hekate

the anabasis of the processions. ${ }^{235}$ If this connection is valid, then the fact that this iconography continues well into the Roman period would indicate that the polis signified this event as a defining moment in their history. A number of dedications to Zeus Panamaros have also been found in the urban center of Stratonikeia, dating from the Roman period, and one might expect future excavations to yield more iconographic representations of the deity. ${ }^{236}$

It is no certainly coincidence that Zeus is often combined with Hekate both gods had expressed their energeia, their divine power in protecting Stratonikeia in two different crises. Impressing onto the coins the images of these patron deities, who were both drawn into town at different moments, was not only a way of sanctifying the circulation, but also a way of publicly

235 I.Stratonikeia $1536-1540$ are dedications to Zeus Panamaros found more recently at Stratonikeia.

236 The anabasis is testified in I.Stratonikeia 161, discussed above under Sacred road. 
advertising these gods and their tight bond with the polis. The longevity of the type is a tribute to the symbolic value of both gods for the city.

In sum, the scope of the sanctuary of Zeus at Panamara underwent four major phases: 1) when the sanctuary of Zeus Karios was administered by the koinon of the Panamareis; 2) a transitional period in the early second century $\mathrm{BC}$, beginning with the priesthood of Leon, when the sanctuary was gradually overtaken by Stratonikeia; 3 ) a period of consolidation, during which the sanctuary appears to have been completely controlled by Stratonikeia; and 4) the period following the attacks of Labienus in 4 О ВС and the miraculous epiphany of Zeus, which marked a phase of expansion of cult and its fame for Stratonikeia. Especially the periods of transition in the second and last phases require some comment. As mentioned above, Leon acted on behalf of both the Panamareis and Stratonikeia when he rallied communities in southern Karia, thereby reinforcing the cult network. As van Bremen argued, Leon's show of goodwill may well have been designed to give the polis a foothold in this area towards the south while creating a friendly corridor to the south through Rhodian territory. ${ }^{237}$ Over a century later the cult underwent another major change, after Zeus's miraculous salvation of the Stratonikeians from Labienus. This came to be a defining moment in the life of the polis but also the cult since Zeus was now known as Zeus Panamaros rather than Zeus Karios. The event was inscribed into social memory via the temple walls, and was used by the polis to obtain a second grant of asylia from Rome. This gave Stratonikeia reason to once again engage its larger network, again at the initiative of a priest who this time wrote personal letters of invitations. This second wave seems to have focused on northern Karia and Ionia, perhaps to strengthen relations in the aftermath of Labienus's attacks in the region. Although we can trace the initiatives of the priests and probably the council of the polis as the agency of change in the development of Stratonikeia, it is clear that the Stratonikeians themselves saw this as the divine will of Zeus, and presented him as the uncontested protagonist of the polis. From this perspective, Dignas' argument that it was the older cult that took the peripheral city into its scope is understandable. ${ }^{238}$ The will of the divine is certainly much more impressive than the blood, sweat, and tears of priests and magistrates. But understanding how the relationship between sanctuary and polis was mediatized to create regional networks, territorial expansion, political power, and social cohesion

237 Van Bremen (2004b), 216-218, 237.

238 Dignas (2002a), 243, mentions Panamara in passing as continuing to be "a centre that itself gradually included the administrative centre into its vision and gave it a religious identification." 
allows us to appreciate the craft of deliberately intertwining the identities of city and cult. Ritually moving Zeus's cult image from the hilltop sanctuary down into town was a theatrical expression of the god's active role in protecting the city, as his festival consumed the urban landscape. The image of the god riding into town was surely reflected in the coinage of Stratonikeia from the mid-first century BC and onwards, no doubt referring to the festival, but also to the deep connection between the god, his sanctuary, and the city. This was the 'subliminal' message that was repeated over and over again, through festivals, feasts, songs, and the images multiplied on the coinage. Zeus's epiphany at Panamara became a charter myth for Stratonikeia.

Interpreting Change in the Relationship between Stratonikeia and Panamara

After its liberation in the mid-second century BC, Stratonikeia adopted an expansionist policy and in light of this the incorporation of Panamara may certainly be seen as a push to the south of the frontiers of the polis. Although the exact territorial boundaries are unknown, Stratonikeia and Panamara are both considered within the northern fringe of the Rhodian 'subject Peraia.239 Debord's hypothesis of Panamara as part of a combined strategy between the polis and the sanctuary to be able to stand up to Rhodes certainly places the sanctuary at the frontiers of these two controlling powers. ${ }^{240}$ Van Bremen's interpretation of Panamara as a hinge connecting Stratonikeia with a number of sympathetic communities in the south, and thereby creating a corridor of goodwill through aggressive Rhodian territory, presupposes a frontier role for the sanctuary as it gives Stratonikeia a foothold in the south. ${ }^{241}$ As she warns, however, the evidence does not support a traditional core-periphery model with a Hellenizing urban center versus an indigenous rural periphery. ${ }^{242}$ This same level of caution should be applied in considering more general theories of frontier sanctuaries, grounded as they tend to be in a similar

\footnotetext{
239 Debord (1994) and (2001a); van Bremen (2004a) and (2008).

240 Debord (2001a), esp. 167.

241 Van Bremen (2004a), esp. 237.

242 E.g. Ramsay, echoes of which are heard in Laumonier, who sees Stratonikeia as a Hellenizing center from the start for the indigenous settlements and sanctuaries in its territory, e.g. Laumonier (1958), 234-235, cited above in Chapter 5, in note 164. Van Bremen objects that "even to speak of a symbiosis between 'new city' and 'old sanctuary' is to misunderstand, fundamentally, the nature of the new city itself," van Bremen (2004a), 223.
} 
dualistic approach. ${ }^{243}$ Panamara might initially have been used as a signpost of Stratonikeian presence at the edge of Rhodian territory, but it would be misleading to impose the polarities of marginal landscapes of nature (versus culture), or wild (versus civilized), onto its topography. In fact, the territory of Stratonikeia was in no sense a void but was instead filled with a diversity of human activity and settlements dispersed across various economic zones. The sanctuary itself had been the social, if not geographical, hub for several of these communities and it seems to be exactly this central position in this cultbased network that attracted the polis. ${ }^{244}$

Like Lagina, Panamara is located near certain natural boundaries that would have played a factor in the location of the cult of Zeus here - it lies along the western fringes of the Marsyas, at the eastern head of a deep valley that extends west and is lined by the Marçat range to the south and the Bencik Dağ to the north. Although not on the most prominent peak, the shrine is on a hilltop that was accessible and defensible while providing a good view. This strategic situation may also be applied to frontier sanctuaries, yet it must be borne in mind that the defensive character of the site primarily played a role during the administration of the Panamareis; it was even used as a garrison by Philip v and probably the Rhodians. Except for the encounter with Labienus, however, this was no longer the main feature of the sanctuary after Stratonikeia took control - instead, Panamara began to develop as an urban space.

Of all of the case studies in this present investigation, Panamara is closest qua location to fulfilling the role of a frontier sanctuary. One may even see it as the product of peer-polity interaction, but instead of leading to rivalry and competition, this was one that sought integration and connectivity through the centrality of the cult. Stratonikeia appears to have used Panamara, especially in the beginning, to build bridges rather than establish borders.

The sanctuary was in any event a beacon of Stratonikeian presence, some 10 kilometers south from the urban center. The several changes discussed in the preceding parts of this section serve to show how the polis interjected itself as central focus of the cult. Interpreting Panamara as a frontier sanctuary emphasizes its role as a landmark of Stratonikeian territory for the outer world. Yet a

\footnotetext{
243 Especially the 'bi-polar model' developed by de Polignac (1984), and de Polignac (1995), for the situation in Archaic Greece, as discussed above in Chapter 2.

244 Frontier sanctuaries could also have a mediatory role; Sinn (1996), esp. 71. describes such sanctuaries at mountain passes in Arcadia as having the acknowledge right of asylia, so as to function as safe channels, providing secure passage for travelers but also for commerce. De Polignac also addresses the aspect of mediation at frontier sanctuaries, although more in the context of competitions, de Polignac (1995). Competition was certainly an aspect at Lagina, but apparently less at Panamara.
} 
number of other issues were also involved in the dynamics of cult and reflect some of the same concerns that we have already seen at Lagina.

Foremost among these concerns must have been social cohesion. In the second century $\mathrm{BC}$, the young polis was a mixture of local Karian villagers and Greek colonists, their descendants, and newcomers from other areas. Festivals, as at Panamara, were an important means of creating a shared focus for the entire and diverse population, regardless of status or origin, and ensured poliswide involvement. Turner's concept of communitas may comes to mind here Panamara certainly was a 'center out there' and the effort of the journey itself would already have been a step in the preparation of the new inclusive experience of rituals. Barbara Kowalzig addressed this concept in relation to theoria, including the dangers of travel, the investment of delegates and the heightened sense of their reward upon success. ${ }^{245}$ She demonstrates how especially effective ritual is in fostering harmony and social cohesion but also its importance as a measure against the opposite. This is clearly the case at Panamara, with the theoria and the inclusive festivals. But what Panamara especially highlights is how the integrative nature of the festivals worked towards creating a sense of urban community. This is very different from Turner's intended use of the concept, in which ritual communitas creates the 'anti-structure' as an alternative to the structure of the city. At Panamara, ritual communitas actually builds the structure of the city.

Festivals provide a common focus that captures everyone's attention and are thus effective vehicles for the transmission of common knowledge; as such they are rational rituals. ${ }^{246}$ Looking at the individual components at Panamara, we can quickly identify the sensory immediacy of music together with the sacrifices as important channels of common knowledge. ${ }^{247}$ Everyone would have witnessed the sacrifices, smelled the smoke and incense, and shared in eating the meat. The hymns sung during the festivals were probably something that everyone knew by heart, recalling memories and creating associations. New hymns would have been composed in accordance with the slant of the new festivals at the sanctuary, especially the Komyria for men and the Heraia for women. These festivals focused on gender or social roles in a way that cut across social boundaries and the deme divisions that were otherwise so prominent in every urban activity; everyone was invited to join whether citizen, foreigner, freedmen, slaves, urbanites, country-dwellers. While going out

245 Kowalzig (2007b), and esp. (2007a), 72: "Theoria as a form of social interaction lies at the heart of Greek religion, basic to its mobility, and to social structure."

246 Chwe (2001), discussed in Chapter 2.

247 Young (1999). 
to the shrine in these predefined groups would actually have maintained these distinctions, the important point is that they did this together, en masse. ${ }^{248}$ A third festival, that of the Panamareia, went beyond the others by bringing the cult image of Zeus into town, on horseback in a procession, an event that must have been spectacular to see and even more exhilarating to be take part in. These processions of Zeus were centripetal, just like the kleidos agoge of Hekate, and they were perhaps the largest link in a chain of actions that served to literally direct the focus of the festivals and the cult towards the city itself. ${ }^{249}$

Using linear ritual space, the processions in general drew the whole civic body across the territory in both directions. Such processions have been interpreted as a statement of domination and control. Yet this was more likely a ritual means of unifying the composite population with each other and with their territory - nearly everyone would have had some stake in the countryside of Stratonikeia and this was a way to make them all intimately familiar with it. Like Lagina, Panamara extended the visual region of the polis, this time to the south. Ritually traversing the landscape brought this 'new territory' at the same time into three-dimensional view, adding it to the domain of the polis and imprinting it via ritual upon the mind's eye. Following Chwe, the public nature of the processions were in themselves crucial towards creating community, but neither as a display of power (Geertz) or in isolation from the city (Turner). More than a pilgrimage, such a loud, conspicuous, and sumptuous public spectacle catching everyone's attention was a highly effective means of 'saturation advertising. The perfect coordinating mechanism, the spectacle fostered the dissipation of common knowledge that is ultimately at the root of social cohesion and collective identity. ${ }^{250}$ The Stratonikeians 'performed the region' through these processions, both by ritually crossing territory and by doing it as publicly as possible, just as they did with Hekate's kleidos agoge. ${ }^{251}$

Finally, incorporating the entire community, but also the entire civic landscape in the most social part of the ritual, namely the feasting, was a way of creating an intense community focus. Feasting took place not only in the urban center but also throughout the territory, even in Lagina, at Hekate's sanctuary in the far north. Everyone was not only feasting at the same time across this vast area, but everyone knew that everyone was doing it too. More than a shared experience, common knowledge creates a mindset that includes social

248 E.g. as suggested in I.Stratonikeia 174 by the mention of a splendid theoria, apparently as a delegation from the polis itself, in lines $4-5$.

249 See Graf (1996) on centripetal processions, discussed above and in Chapter 5 .

250 Chwe (2001), 21.

251 Donaldson (2006); the kleidos agoge is discussed above in Chapter 5, under Ritual performance. 
memories and expectations. This laid the foundations for cohesion and collective identity across the composite communities of the rising polis.

The festivals of Zeus and Hera were thus reinvented and turned into rational rituals that served to unite the very diverse population base of Stratonikeia, but they were also used to establish networks with communities outside the polis. Especially priests had a large share of this responsibility, as they were the ones who took the initiative in contacting other communities. This began with Leon who, around the mid-second century вС, strengthened the central position of Panamara in the surrounding area by physically going to communities and getting them to increase their involvement in the festivals of Zeus, and so with each other. Although the record is scanty, the scope of his activities appears to have been targeted at the south, towards communities still within Rhodian territory. Over a century later, after the miraculous rescue of the polis by Zeus, priests may well have been behind the delegation to Rome. In any event, the divine intervention was used to obtain the right of asylia from the Senate, enabling Stratonikeia to further promote Panamara among a much wider circle, as it had been done before with Lagina. The evidence is lacunose, yet it seems this time that they were more interested in local Karian communities to the north and northeast, and perhaps Ionia, as Miletos was one of the communities addressed. A third wave is seen by the efforts of yet another priest who took the initiative to expand the cult network of Panamara by personal invitation. This time the targets appear to have been poleis along the northern edge of Karia, and farther along the coast, even including Smyrna, but also the Rhodian community, as he appealed to them based on claims of syngeneia, or kinship, through cult. The sanctuary of Zeus at Panamara served to consolidate the regional network of Stratonikeia by association with the cult of Zeus. Important mediators in the first two waves were grants of asylia, while the ties of syngeneia were pivotal for the third wave of network establishment. As Ma discussed, asylia and syngeneia were concepts of connectivity that were globally understood throughout the Greek world. ${ }^{252}$

Both the emphasis on social cohesion through the cult and the use of it to build wider network developments are important steps in the development of regional identity. As with Lagina, it is easy to follow the ways in which Panamara was instrumental in constructing the identity of the polis when we consider the four basic stages of region building as identified by Anssi Paasi: territorial shaping; symbolic shaping; institutionalism; and the establishment through external recognition. ${ }^{253}$ Territorial shaping already began with the

$252 \mathrm{Ma}$ (2003), discussed in Chapter 2.

253 Paasi (2009), 133-137; see also above in Chapter 5. 
incorporation of the Karian villages around Stratonikeia. The cult of Hekate at Lagina especially seems to have provided a central focus for these communities - her cult already seems to have belonged to the Stratonikeians by the early second century BC, during the period of Rhodian rule. At that time, the cult of Zeus Karios at Panamara was still being administered by the koinon of the Panamareis, and the polis does not appear to have played a leading role at the sanctuary until after the end of Rhodian rule. Drawing Panamara into the orbit of the polis must represent a second phase of Stratonikeian expansion, at whatever pace this took. As the polis gained control of the sanctuary, it came to share the focus of cult with Zeus and Hera, as the dedication including the demos indicates. ${ }^{254}$ It may well be Zeus Karios whose image appeared back-to-back with Hekate on the first coinage of Stratonikeia in the midsecond century вс. By the mid-first century, the symbiotic relationship between Stratonikeia and Panamara was proven by Labienus, who attacked the shrine in lieu of the city. This event in itself marked a critical turning point in this relationship, in which Zeus took on a highly personal role as manifest divine protector of the city.

The polis could not have chosen a more effective symbol than the image of a supreme being whose divine will it was to watch over the city. Even more than the pomp and ceremony of the festivals and processions, this singular miraculous event, with all of its special effects, is the perfect spectacle to create 'flashbulb memories', crucial for accurate recall but also for religious and cultural transmissions. ${ }^{255}$ Whatever took place on the hilltop in 39 вC, the important thing that matters is that it was collectively perceived by the Stratonikeians as the intervening hand of their god that saved their city from destruction. ${ }^{256}$ They clearly mattered to Zeus and their very existence was due to his divine will. Gehrke's 'intentionale Geschichtsschreibung' can help interpret the role of epiphanies and their strategic use by cities to highlight their own position along different geopolitical axes. ${ }^{257}$ Public memory is crucial in this regard. The way in which the Stratonikeians dealt with the event is highly self-conscious, given the various ways in which it was commemorated, e.g. the embassy to

\footnotetext{
254 I.Stratonikeia 332.

255 McCauley and Lawson (2002), 56-64.

256 On collective epiphanies and their perceptions, see also Rostowzew (1920) and Graf (2004); also Picard (1952) and Pritchett (1979), 11-46, who both conclude that epiphanies in warfare often take atmospheric shapes, such as unseasonal weather.

257 Gehrke (1994). Dillery understands this 'intentional history' as “... historiography written both to articulate the identity of a given region of the Greek world and to proclaim the region's importance in a larger, changing world," Dillery (2005), 507. For the reference to Zeus Panamaros, Dillery (2005), 519-520.
} 
Rome and the grant of asylia, the festivals of the Panamareia, the processions, the transformation of Zeus as a rider-god on the coinage. All of these manifestations have a potent symbolic value, and yet the greatest symbol was the story itself, inscribed on the walls of the sanctuary, most likely on the temple itself, as 'lieu de memoire', but also in such a way that the story of 'How Zeus Protected the Stratonikeians' would accurately be remembered and told for generations to come, etching itself into social memory. In line with this, re-naming the god from Zeus Karios to Zeus Panamaros re-centered his identity on the very hilltop where this defining event for the polis took place, rather than ambiguously extending it across the wider region of Karia; Zeus himself had also acquired a new focus, and that focus was squarely centered on Stratonikeia.

The third stage in region building is institutionalism, and as with the cult of Hekate, this may be seen through the festivals and especially the priesthoods that were established at Panamara. The active role of the priests of Zeus as statesmen and urban leaders has already been discussed at length, including the suggestion that they had a large role in intertwining the cults of Zeus and Hekate, since the same persons or family members often held both positions at different times, at least in imperial times. The priests at Panamara were perhaps the most important actors in region-building - they certainly occupied the role of 'economic, political and cultural/media elite' that Paasi sees as crucial in establishing the institutions essential towards regional identity. ${ }^{258}$

The final stage of the establishment of the region through external recognition may be seen in the networks, discussed above, of communities that were represented at Panamara, particularly when the polis had full control over the sanctuary. Whether directly following the grant of asylia, or participating in festivals through ties of syngeneia, the cities whose names appear on the list and who were invited to the festivals acknowledged the intricate bond between Zeus Panamaros and Stratonikeia. City and sanctuary were thus linked through a variety of media, including decrees, processions, songs, festivals, name-giving, and even coinage, in a message that was repeated over and over again. This was the best way to imprint the interlocking pattern of deity, city, and place onto collective memory, thus foregrounding this place as a second bright dot on the cognitive topography of the Stratonikeians, as well as the surrounding communities. The longevity of this reiterated message, until the third or even early fourth century AD, testifies to the success of the

$25^{8}$ Paasi (2009), 133: "Region-building can be understood only in a framework of social division of labour and this accentuates particularly the role of (regional) economic, political and cultural/media elites in the production of regions and identity narratives." 
way in which the god was used in the Hellenistic period to symbolically shape the polis.

The incorporation of Panamara shifted the focus of the sanctuary to the north, as it realigned the mental maps of both the Stratonikeians and the surrounding communities. The sanctuary that had once served the southern parts of Karia around the Marsyas valley was now permanently drawn into the orbit of the polis, becoming one of its principal urban platforms. In the relationship between city and sanctuary we should highlight both the agency of the priests, through their initiative, and of the population, through their active participation. Yet in the eyes of the Stratonikeians the principal actor was Zeus himself. In fact, Zeus and Hekate both go to town in their centripetal processions, putting an interesting twist on the idea of center and periphery. The Stratonikeians surely would have appreciated Dignas' view of the agency at the shrine of Zeus Panamaros, as pulling Stratonikeia into the orbit of the god.259 The polis certainly took its religious identity from Zeus, and from Hekate, but in the meantime it rewrote both cults to conform to its own needs of a center of gravity to pull together its heterogeneous population base and establish its position in the greater urban world.

259 Dignas (2002a), 243, cited above in note 239. 